Insider Trading Deterrence versus Managerial Incentives: A Unified Theory of Section 16(b) Author(s): Merritt B. Fox

Source: Michigan Law Review, Vol. 92, No. 7 (Jun., 1994), pp. 2088-2203

Published by: Michigan Law Review Association

Stable URL: http://www.jstor.org/stable/1289660

Accessed: 15-10-2015 15:29 UTC

Your use of the JSTOR archive indicates your acceptance of the Terms \& Conditions of Use, available at http://www.jstor.org/page/ info/about/policies/terms.jsp

JSTOR is a not-for-profit service that helps scholars, researchers, and students discover, use, and build upon a wide range of content in a trusted digital archive. We use information technology and tools to increase productivity and facilitate new forms of scholarship. For more information about JSTOR, please contact support@jstor.org. 


\title{
INSIDER TRADING DETERRENCE VERSUS MANAGERIAL INCENTIVES: A UNIFIED THEORY OF SECTION 16(b)
}

\author{
Merritt B. Fox*
}

TABLE of Contents

INTRODUCTION .................................. 2089

I. IDENTIFying the Costs of A Rough Rule of Thumb: The Impact of Section 16(B) on Managerial InCEntives......................

A. The Importance of the Managerial Incentive Structure ...............................

B. The Impact of Section 16(b) on Managerial Incentives ................................. 2106

II. A General Theory ........................ 2107

A. A World With Only Positive Inside Information

1. Purchase and Sale Behavior in the Absence of Section 16(b) .........................

2. The Six-Month Rule of Inference ...........

3. Purchase and Sale Behavior If Section 16(b) Is Applied

4. Conclusion ...............................

B. A World With Only Negative Inside Information.

1. Purchase and Sale Behavior If Section 16(b) Is Not Applied

2. The Six-Month Rule of Inference ..........

3. Purchase and Sale Behavior If Section 16(b) Is Applied

C. A World With Both Positive and Negative Inside Information

* Professor of Law, University of Michigan. B.A. 1968, J.D. 1971, Ph.D. (Economics) 1980, Yale. - Ed. The author wishes to express his appreciation to Professors Richard Friedman, Avery Katz, Kyle Logue, Joel Seligman, and Thomas Ulen and to the participants in the Law and Economics Workshop at the University of Illinois and the Faculty Workshop at the University of Iowa Law School for their helpful comments on earlier drafts of this article. The author also acknowledges, with thanks, the research assistance of Andrew Cohen, Matthew Gutwein, and William Koski. Financial support for this project was provided by the Cook Fund of the University of Michigan. 
1. Direct Applicability of the Preceding Models.................................

2. Combining the Models................ 2136

III. Determining the Reach of the Statute....... 2138

A. An Overall Principle of Decision ............ 2139

B. Must the Term in Office Include the Time of

Purchase or Sale?..........................

1. The Time of Purchase .................. 2141

2. The Time of Sale ..................... 2151

C. Market-Acquired Options.................. 2153

1. The Purchase and Sale of Calls .......... 2153

2. The Purchase of a Call Followed by Its Exercise and the Sale of the Share ........ 2160

3. The Purchase of a Share Followed by the Purchase of a Put.......................

D. Stock-Price-Based Officer and Director

Compensation Plans - Employee Stock

Options and Stock Appreciation Rights.........

1. Application of the Rule of Decision ........ 2182

2. Court Decisions and Pre-1991 SEC Rulemaking ......................... 2183

3. The 1991 Rule Revisions ................. 2190

Conclusion ...................................... 2201

\section{INTRODUCTION}

Officers and directors have special access to information that they can use to profit in the purchase and sale of their company's securities. Section 16(b) of the Securities Exchange Act of 1934 (Exchange Act) ${ }^{1}$ is the only provision of the federal securities laws explicitly designed to deter such transactions. ${ }^{2}$ To accomplish its purpose, section 16 (b) requires insiders to disgorge to the company any profit they realize from "any purchase and sale, or any sale and

1. Securities Exchange Act of 1934 (Exchange Act), ch. 404, § 16(b), 48 Stat. 881, 896 (codified at 15 U.S.C. $\$ 78 \mathrm{p}(\mathrm{b})(1988)$ ).

2. Section $10(\mathrm{~b})$ of the Exchange Act, while authorizing the Securities and Exchange Commission (SEC) to define fraudulent or deceptive acts of securities manipulation, does not explicitly forbid insider trading or any other particular practice. See Exchange Act $\S 10$ (b), 15 U.S.C. $\$ 78 \mathrm{j}$ (1988). Pursuant to its delegated authority, the SEC adopted rule $10 \mathrm{~b}-5$, which prohibits fraud in securities transactions but does not specifically mention insider trading. See 19 C.F.R. $\$ 240.10 b-5$ (1993). In 1961, the SEC held that rule 10 b-5 forbids insider trading in both face-to-face transactions and anonymous stock exchanges. In re Cady, Roberts \& Co., 40 S.E.C. 907 (1961). Thus, while $\S 10$ (b) may be applied to insider trading via rule $10 \mathrm{~b}-5$, neither the section nor the rule is specifically designed to reach this practice. 
purchase, of any equity security" of the company within a sixmonth period. ${ }^{3}$

Does section 16(b) in fact deter officers and directors from trading on the basis of nonpublic information? ${ }^{4}$ If so, to which pairs of transactions should section 16(b) be applied among all that the statute's language can be stretched to cover? Proper answers to these fundamental questions require a coherent theory of section 16(b)'s application. This theory should determine whether and how a penalty on short-swing transactions deters insider trading, and it should account for the costs of imposing this penalty. Despite section 16(b)'s sixty years of existence, the courts and legal scholars have yet to develop such a theory. ${ }^{5}$ This article intends to fill this void,

3. The full text of $\S \S 16(a)$ and $16(b)$ of the Exchange Act, as amended, reads as follows:

Sec. 16. (a) Every person who is directly or indirectly the beneficial owner of more than 10 per centum of any class of any equity security (other than an exempted security) which is registered pursuant to section 12 of this title, or who is a director or an officer of the issuer of such security, shall file, at the time of the registration of such security on a national securities exchange or by the effective date of a registration statement filed pursuant to section $12(\mathrm{~g})$ of this title, or within ten days after he becomes such beneficial owner, director, or officer, a statement with the Commission (and, if such security is registered on a national securities exchange, also with the exchange) of the amount of all equity securities of such issuer of which he is the beneficial owner, and within ten days after the close of each calendar month thereafter, if there has been a change in such ownership during such month, shall file with the Commission (and if such security is registered on a national securities exchange, shall also file with the exchange), a statement indicating his ownership at the close of the calendar month and such changes in his ownership as have occurred during such calendar month.

(b) For the purpose of preventing the unfair use of information which may have been obtained by such beneficial owner, director, or officer by reason of his relationship to the issuer, any profit realized by him from any purchase and sale, or any sale and purchase, of any equity security of such issuer (other than an exempted security) within any period of less than six months, unless such security was acquired in good faith in connection with a debt previously contracted, shall inure to and be recoverable by the issuer, irrespective of any intention on the part of such beneficial owner, director, or officer in entering into such transaction of holding the security purchased or of not repurchasing the security sold for a period exceeding six months. Suit to recover such profit may be instituted at law or in equity in any court of competent jurisdiction by the issuer, or by the owner of any security of the issuer in the name and in behalf of the issuer if the issuer shall fail or refuse to bring such suit within sixty days after request or shall fail diligently to prosecute the same thereafter; but no such suit shall be brought more than two years after the date such profit was realized. This subsection shall not be construed to cover any transaction where such beneficial owner was not such both at the time of the purchase and sale, or the sale and purchase, of the security involved, or any transaction or transactions which the Commission by rules and regulations may exempt as not comprehended within the purpose of this subsection.

Exchange Act $\S 16$, ch. 404, 48 Stat. 881, 896, as amended by Act of Aug. 20, 1964, Pub. L. No. 88-467, § 8(a), 78 Stat. 565, 579 (codified at 15 U.S.C. $\$ 78$ p (1988)) (emphases added).

4. Section 16(b) also includes in its list of statutorily defined insiders the beneficial owners of more than $10 \%$ of the shares of any class of the issuer's equity securities. See supra note 3. Its application to these persons involves issues of policy and statutory interpretation somewhat different from its application to officers and directors and thus will not be the focus of this article.

5. Two legal scholars, Steve Thel and Karl Okamoto, have each recently developed general theories of $\S 16$, but they are not theories of how $\S 16$ combats insider trading. Karl S. Okamoto, Rereading Section 16(b) of the Securities Exchange Act, 27 GA. L. Rev. 183 (1992); Steve Thel, The Genius of Section 16: Regulating the Management of Publicly Held Compa- 
using the techniques of modern financial economics, the theory of the firm, and analogies to basic concepts of statistical inference. The theory developed here shows that a penalty on short-swing trading deters insider trading and suggests a simple framework for deciding on which pairs of transactions to impose the penalty. ${ }^{6}$

Section 16(b) is one of the most important provisions of the federal securities laws. Section 16 has been the subject of more interpretations by the staff of the Securities and Exchange Commission (SEC) than any other provision. ${ }^{7}$ If the talk of inside corporate counsels is to be believed, section 16(b) gives rise to a substantial portion of the securities work of their offices as well. It was the basis of a claimed cause of action in twenty-four reported cases between 1987 and 1992, ranking it eighth among all provisions of the federal securities law, ${ }^{8}$ and it has spawned a small industry of plaintiffs' lawyers. ${ }^{9}$ It probably plays a larger day-to-day role in constraining the behavior of America's corporate executives than rule

nies, 42 Hastings L.J. 391 (1991). Each theory instead rests on the unlikely proposition that despite the language of $\S 16(\mathrm{~b})$ 's preamble - "For the purpose of preventing the unfair use of information that may have been obtained . . . " - combatting insider trading is not $\S 16(\mathrm{~b})$ 's primary purpose. See infra note 87 for a further discussion of their works.

6. The desirability or undesirability of insider trading is a controversial question that has been addressed extensively in legal and economic literature. For a critical survey of that debate, see Merritt B. Fox, Insider Trading in a Globalizing Market: Who Should Regulate What?, LAw \& Contemp. Probs., Autumn 1992, at 263, 266-90. Rather than attempting to add further to this debate, this article starts with the assumption that society has decided it wants to deter insider trading.

7. Ownership Reports and Trading by Officers, Directors and Principal Stockholders, Exchange Act Release No. 26,333, [1988-1989 Transfer Binder] Fed. Sec. L. Rep. (CCH) II 84,343 , at 89,600 (Dec. 2, 1988) [hereinafter Initial Release].

8. This figure is based on a Westlaw search, conducted by the author, of reported cases for the period 1987 through 1992. Search of Westlaw, Securities and Blue Sky Law Database, FSEC-CS File (October 1993) (search of federal securities cases, using the section numbers relating to all of the securities laws likely to be the basis of a cause of action). The number of reported cases in fact probably understates the impact of $\S 16(b)$ on the behavior of insiders because, over a wide range of possible situations, its applicability can be determined mechanically. Insiders know with relative certainty much of the behavior that must be avoided in order to stay clear of $\S 16$ (b)'s sanctions, unlike, for example, rule 10b-5, the Exchange Act's catchall antifraud provision, which generated the most reported cases. With a smaller gray area of uncertain application, a given amount of behavior alteration resulting from the statute can be expected, ceteris paribus, to be accompanied by less behavior that gives rise to legal disputes. Moreover, those disputes that do arise are more likely to be settled and will thus give rise to fewer litigated cases. See George L. Priest, Measuring Legal Change, 3 J.L. ECON. \& ORG. 193, 199-200 (1987) (concluding that less uncertainty concerning a legal standard will result in fewer litigated cases).

9. Committee on Fed. Reg. of Sec., Report of the Task Force on Regulation of Insider Trading - Part II: Reform of Section 16, 42 Bus. LAw. 1087, 1134 (1987) (noting that "[a]n active plaintiffs' bar has been extremely effective in seeking disgorgement of short-swing profits under section $16(\mathrm{~b}) ")$. 
10b-5's headline-grabbing, judge-made strictures against insider trading. ${ }^{10}$

Section 16(b) is unusual in that it seeks to accomplish its stated purpose by indirect means rather than by direct prohibition. ${ }^{11}$ The statute's operation does not depend on whether there is any direct evidence of the use of inside information. Instead, it identifies certain pairs of transactions in terms of their nature and timing and in effect conclusively presumes that inside information was in some way used in connection with one or both of the transactions in the pair. Section 16(b), therefore, is the paradigm of a crude legal rule of thumb. Because it applies automatically and without respect to the actual use of inside information, section 16(b) imposes sanctions in some circumstances on insiders who have not relied on inside information in deciding whether to trade. The sanctions imposed on persons who have not used inside information are justified because they facilitate the imposition of sanctions on persons who have traded on the basis of inside information.

Section 16(b)'s indirectness makes the questions of efficacy and rational application particularly critical. If the statute is not effective at deterring insider trading, the costs it imposes on persons who are not trading on inside information are unjustifiable. If the statute is effective, the costs imposed on innocent traders need to be considered in constructing a rational approach to its application.

10. Rule $10 \mathrm{~b}-5$ requires corporate insiders to disclose or abstain from trading only when they possess material inside information. The seminal case defining materiality for rule $10 \mathrm{~b}-5$ cases states that possessing such information is "essentially extraordinary in nature." SEC v. Texas Gulf Sulphur Co., 401 F.2d 833, 848 (2d Cir. 1968) (quoting Arthur Fleischer, Jr., Securities Trading and Corporate Information Practices: The Implications of the Texas Gulf Sulfur Proceeding, 51 VA. L. Rev. 1271, 1289 (1965)), cert. denied, 394 U.S. 976 (1969). In contrast, insiders must consider $\S 16(\mathrm{~b})$ in deciding the timing of every purchase and sale. As will be seen, the statute also has major effects on the design of share-price-based executive compensation. Moreover, $\$ 16(\mathrm{a})$, which is intended to provide outsiders with the information necessary to enforce $\S 16(\mathrm{~b})$, requires each officer and director to make monthly filings of any purchases or sales of his or her issuer's equity securities. Exchange Act $\S 16(\mathrm{a}), 15$ U.S.C. $§ 78 p(a)(1988)$.

11. In some sense, even statutes that purport to prohibit directly a disapproved activity accomplish their purpose indirectly. Consider the application of a directly prohibitory statute. The finder of fact cannot directly observe whether or not a violation has occurred, and the application of the statute depends on the operation of evidentiary rules and presumptions. Thus a directly prohibitory statute can be said to work indirectly too in the sense that the behavior that the statute deters is only that behavior that can be expected to give rise to a record that will lead to a finding of a violation by a finder of fact employing set presumptions and rules of evidence. All that differentiates $\S 16(\mathrm{~b})$ from directly prohibitory rules like rule $10 \mathrm{~b}-5$ is the openness with which the section lays out the process for its application and the strength and simplicity of its presumptions. To the extent that there is commonality between $\S 16$ (b) and directly prohibitory statutes, this article can be taken to address how as a general matter we should approach questions of statutory efficacy and coherent application. 
There is an obvious reason to doubt section 16(b)'s efficacy. To avoid the statute's sanctions, all that an insider trader needs to do is to wait six months. This observation causes some prominent commentators to believe that section 16 (b) is simply a trap for the unwary that should be repealed. ${ }^{12}$ This criticism, however, rests on an assumption that the six-month wait in and of itself does not deter insider trading. The theory developed here shows this assumption to be incorrect.

Rational application of section 16(b) might not seem so difficult at first blush because the statutory language is quite straightforward. A moment's reflection, however, suggests a wide variety of situations beyond the simple cash purchase or sale of a security that would permit an individual to alter her financial position so that her wealth will be either increased if share price subsequently goes up or protected from decrease if share price subsequently goes down. Every such situation presents an insider possessing nonpublic information with an opportunity to benefit in ways the public cannot. Thus, to be consistent with the statute's underlying purpose of preventing unfair use of information, we might want to apply the words purchase and sale to a variety of insider transactions. Such

12. Richard Jennings, Harold Marsh, and John Coffee express a very skeptical view concerning the usefulness of $\S 16(b)$ :

Judging solely from the facts stated in the opinions in the decided cases, the function of Section 16(b) would appear to be to impose unjust liability upon entirely innocent persons. However, the justification of the section lies supposedly in its in terrorem effect upon potential inside manipulators. It has never been demonstrated whether this principle of "Punish the innocent, in order to terrorize the guilty" works to any extent, and no one has even made an attempt to produce such evidence. It would seem clear, however, that any moderately bright manipulator should be able in many cases to string out his activities over a period of more than six months and thus escape any penalty under the section.

Richard W. Jennings et al., Securities Regulation: Cases and Materials 1363-64 (7th ed. 1992) (footnote omitted). For similar reasons, a number of commentators have called for the outright repeal of $\S 16(\mathrm{~b})$. See Marleen A. O'Connor, Toward a More Efficient Deterrence of Insider Trading: The Repeal of Section 16(b), 58 FordHAM L. REv. 309 (1989); S.S. Samuelson, The Prevention of Insider Trading: A Proposal for Revising Section 16 of the Securities Exchange Act of 1934, 25 HARV. J. ON Legis. 511, $522-28$ (1988); Michael R. Klein, Outsider Proposes Changes in Insider Trading Bill, LegAL Times, Dec. 12, 1983, at 8; William H. Painter, Time for an Overhaul, A.B.A. J., Mar. 1, 1987, at 38.

Supporters of $\S 16(\mathrm{~b})$, rather than attempting to rebut these criticisms, tend to be dogmatic about the need for its retention. Jennings, Marsh, and Coffee recount, for example, that "[t]he Advisers to the American Law Institute's Securities Code Project were told by the Reporter [Louis Loss] that no discussion would be permitted of the policy of Section 16(b); it had to be accepted as sacred." JenNings ET AL., supra, at 1364. In a similar vein, Marc Steinberg and Daryl Landsdale, Jr., without any acknowledgment of the criticisms leveled at $\S 16(\mathrm{~b})$, chastise the SEC for recent restrictions in the reach of $\S 16(\mathrm{~b})$ as "giving away a crown jewel" in its announced “'war' on insider trading." Marc I. Steinberg \& Daryl L. Landsdale, Jr., The Judicial and Regulatory Constriction of Section 16(b) of the Securities Exchange Act of 1934, 68 Notre Dame L. Rev. 33, 69 (1992). 
stretching of statutory terms has a long tradition in the securities laws.

It is not obvious, however, which transactions the statute should be stretched to cover. A variety of issues has arisen. For example, for section 16(b) to apply, need the trader be an insider at the time of both the first and the second transactions in the matched pair? Is the acquisition of a call option the "purchase" of an "equity security," and should it make a difference whether the option is acquired in the market or pursuant to a management stock option plan? Should the acquisition of a put option be considered a "sale?" How should the exercise of an option and the subsequent sale of the resulting shares be handled? Should the exercise of stock appreciation rights be treated as involving the simultaneous "purchase" and "sale" of a security even though as a formal matter no securities are involved at all? As this article will show, the record of the SEC and the courts in dealing with these issues has been one of inconsistent treatment of essentially like transactions, frequent conflict among courts and between the courts and the SEC, and numerous reversals of position by both institutions. ${ }^{13}$ The courts and the SEC seem lost without the compass of a theory of the costs and deterrent impact of section 16(b)'s short-swing penalty against insider trading.

Part I of this article assesses the social costs of a crude rule of thumb. Because section 16(b) applies to a given class of paired transactions, it deters both transactions based on inside information and transactions not so based. Each time section 16(b) is stretched to include a class of paired transactions, it deters some additional innocent transactions. This side effect will take the form of officers' and directors' purchasing fewer shares in their own companies and refusing to accept as large a portion of their compensation in a form based on share price. There are strong theoretical and empirical reasons to believe that managerial share ownership and share-pricebased compensation are important to the proper functioning of our economy because of the significant incentives they provide for aligning the otherwise divergent interests of management and shareholders. The weakening of these incentives is a social cost of including a given class of paired transactions within the reach of section 16(b).

13. See infra Part III. Decisions concerning the reach of the statute fall to the SEC and to the courts. The SEC makes rules that help define the terms of the statute and that exempt certain transactions as not comprehended within its purposes. In their adjudication of individual cases, the courts interpret the terms of the statute and review the validity of the SEC's rules. 
Part II develops a theory of how a penalty on short-swing trades works in the case of transactions clearly covered by the statute ordinary cash purchases and sales of securities. It utilizes portfolio theory - the mainstay of modern financial economics - to predict the effect of a short-swing penalty on the respective behaviors of insiders who are and who are not trading on inside information. The fact that transactions occur within six months of each other increases the likelihood that one of them is based on inside information - an increase that is significant over a wide range of plausible values for the relevant parameters. Imposing a penalty on short-swing transactions discourages trades based on inside information by forcing those who would engage in them to remain "dediversified" for six months and hence to be at greater financial risk than they would be without the statute. This theory of section 16(b)'s operation, it will be shown, suggests that purchase and sale should be defined in terms of when the increase in portfolio risk is assumed and when it ends. This theory suggests that the statute should only be concerned with the possibility of abuse at the time of the first transaction.

Part III employs the lessons of Parts I and II to solve the actual problems faced by the SEC and the courts in applying section 16(b) to cases other than pairs of ordinary cash-for-security transactions clearly covered by the statute. It begins by proposing an overall principle of statutory reach derived from the statute's internal logic, from other evidence of congressional intent, and from a concern for economic efficiency: a given class of paired transactions should be included within the coverage of section $16(\mathrm{~b})$ only if the potential officer-and-director transactions belonging to the class, because they are separated by less than six months, contain a larger portion of transactions motivated by inside information than do potential officer-and-director transactions generally. Guided by the theory developed in Part II, this overall principle of statutory reach is then applied to a number of hypothetical examples. This approach is compared with the approaches used by the courts and the SEC dealing with the same issues. As will be seen, the approach based on the theory developed in Part II suggests simple, clear, supportable solutions to a number of problems with which the courts and the SEC have struggled for decades.

Particular attention is paid to the wholesale reform of the section 16 rules adopted by the SEC in 1991 . Judged by the approach advocated here, these reforms, though not perfect, are a large step forward. The new rules are, however, highly controversial, and 
they are in many cases vulnerable to judicial invalidation because they represent reversals of policy by the SEC or take positions contrary to prior judicial interpretations of the statute. The approach advocated here provides significantly stronger rationales with which to defend these reforms than the ones so far provided by the SEC.

\section{Identifying the Costs of a Rough Rule of Thumb: The IMPACT OF SECTION 16(B) ON MANAGERIAL INCENTIVES}

Section 16(b), because it uses a crude rule of thumb, will inevitably burden officers and directors in some situations in which these individuals would not in any event have engaged in insider trading. The social cost of this burden is important in determining both whether the statute is worthwhile at all and, if it is, which classes of paired transactions the statute should reach. To understand the nature and extent of these social costs, one needs to see the effects of the burden in context. How do the decisions of corporate management affect our economic welfare? What is the structure of incentives in which corporate managers make these decisions? How does the burden imposed by section 16(b) on officers and directors not engaging in insider trading impinge on that structure of incentives?

\section{A. The Importance of the Managerial Incentive Structure}

The managers of large, publicly held corporations are delegated a large portion of the fundamental "line" decisions in our economy: they determine how existing productive capacity should be employed and what new projects should be implemented. ${ }^{14}$ If the choices made are the ones that maximize shareholder wealth, they are generally presumed also to be the ones that constitute the most efficient allocation of society's scarce resources. ${ }^{15}$ There is no assurance, however, that the managers of these corporations will

14. The impact of these managerial decisions on the economy cannot be overstated. Historical data suggests that about $75 \%$ of the nation's industrial assets are controlled by the largest five hundred industrial corporations and that these firms are responsible for a roughly comparable proportion of new investment. Merritt B. Fox, Finance AND Industrial Performance in a Dynamic Economy 117 (1987) (surveying a number of data sources leading to this picture).

15. Conventional economic theory holds that in a competitive economy in which antisocial behavior, such as pollution, is properly regulated, management decisions that are best for existing shareholders are also the ones that allocate the economy's scarce resources most efficiently. William J. Baumol, Economic Theory and Operations Analysis 395-400 (4th ed. 1977); Milton Friedman, Capitalism and Freedom 133 (1962); Paul A. Samuelson \& William D. Nordhaus, Economics 678 (12th ed. 1985). 
make their decisions in this fashion. A corporate manager, like anyone else, can be expected to value compensation, perquisites, respect, power, affection, a sense of rectitude, and job security. Almost every decision the manager makes for the firm will affect the level of at least some of these rewards. The question is how. The extent to which a manager's decisions maximize shareholder wealth depends on the structure of incentives. Correctly structuring incentives for delegated decisionmakers is the focus of agency theory an increasingly prominent field of economics ${ }^{16}$ - and it has become the central concern of the modern study of corporate law as well. ${ }^{17}$

Greater success at structuring corporate managers' incentives may be crucial to our national economic welfare. With the decline in the growth rates of U.S. productivity and per capita income over the last two decades has come increasing criticism of the quality of management decisions made in U.S. corporations. Many observers assert that these decisions are characterized by lack of imagination, toleration of too much slack, a costly overemphasis on the short run, and overly generous perquisites given to high-level execu-

16. Seminal agency-theory articles include Armen A. Alchian \& Harold Demsetz, Production, Information Costs, and Economic Organization, 62 AM. Econ. Rev. 777 (1972); Stephen A. Ross, The Economic Theory of Agency: The Principal's Problem, 63 Am. Econ. Rev. (PAPERS \& Proc.) 134 (1973); and Steven Shavell, Risk Sharing and Incentives in the Principal and Agent Relationship, 10 Bell J. Econ. 55 (1979). Michael Jensen and William Meckling, in what has become perhaps the most-cited economics article in corporate law, first applied agency-theory concepts in a systematic way to the relationship between shareholders and management. See Michael C. Jensen \& William H. Meckling, Theory of the Firm: Managerial Behavior, Agency Costs and Ownership Structure, 3 J. Fin. Econ. 305 (1976). Jensen and Meckling's article has spawned a large literature within financial economics as well. See, e.g., Symposium on the Distribution of Power Among Managers, Shareholders, and Directors, 20 J. Fin. Econ. 3 (1988).

17. Berle and Means brought to the center of scholarly attention the dispersion of share ownership and, in their view, the resulting impotence of shareholders in constraining managers from making decisions contrary to the best interests of shareholders. Adolf A. Berle, Jr. \& Gardiner C. Means, The Modern Corporation and Private Property (1933).

Jensen and Meckling formalized the effects of the separation of share ownership from control and developed the concept of "agency costs" - the sum of the costs of measures to reduce the deviations from shareholder best interests and the residual deviations - that has become the paradigm for much of corporate law scholarship. See Jensen \& Meckling, supra note 16. A leading corporate law casebook, which includes in its introductory material a discussion of the agency-cost model, starts with the observation that "[a]lthough many economists dispute the Berle-Means thesis that shareholders lack the capacity to control management, all recognize that potential conflicts exist between managers and shareholders." JESSE H. Choper et al., Cases and Materials on Corporations 25 (3d ed. 1989). Choper, Coffee, and Morris conclude their introductory materials with the following observation:

[C]ontemporary debate ... is between ... those who advocate corporate law reforms in the belief that increased regulatory or institutional reforms ... will reduce agency costs, and those ... who reject such reforms on the grounds that agency costs have already been minimized as a result of voluntarily adopted monitoring controls and the incentive effects created by existing management compensation systems. Id. at 28 . 
tives. ${ }^{18}$ Others complain that managers of many firms unjustifiably retain cash flow just to maintain or enlarge their domain; they use the retained cash flow for investment in inferior projects or inappropriate acquisitions within the firm, rather than pay it out to shareholders who could reinvest it through the capital market in other firms that are engaged in more promising projects. ${ }^{19}$ Although the specifics of these criticisms are the subject of debate, there is one proposition on which the debaters are likely to agree: a firm's management is more likely to be making good decisions if it is operating within a structure of incentives that promotes such decisions.

Managers face a number of pressures of varying intensity that help align their interests with those of shareholders: the threat of legal action for violation of fiduciary duties, the threat of hostile takeover, the managerial labor market, the evolutionary growth or decline of the firm as the result of succeeding or failing in product competition, peer review, the discipline of the outside directors, and the threat of removal by dissatisfied shareholders.

The impact of corporate and securities law on these pressures has been the subject of much study over the years. Traditionally most corporate and securities scholars concerned with pressures on

18. See Graef S. Crystal, In Search of Excess: The Overcompensation of AmerICAN EXECUTIVES 96-109 (1992) (arguing that executive pay is excessive and not tied closely enough to company performance); Robert H. Hayes \& William J. Abernathy, Managing Our Way to Economic Decline, HARv. Bus. Rev., July-Aug. 1980, at 67 (arguing that the decline in productivity of U.S. corporations compared to Germany and Japan is attributable to a focus on short-term profitability that excludes investment in technological innovations whose payoff is longer term); Michael E. Porter, Capital Disadvantage: America's Failing Capital Investment System, HARV. Bus. REv., Sept.-Oct. 1992, at 65 (arguing that U.S. corporations invest too little in research and development and "nontraditional" forms of investment such as human resource development); Alfred Rappaport, Executive Incentives vs. Corporate Growth, HaRv. Bus. Rev., July-Aug. 1978, at 81 (attributing low capital investment, poor improvements in labor productivity, and low spending on research and development - the causes as he sees them of the slowdown in U.S. growth - to short-term managerial incentives).

19. See Fox, supra note 14, at 122-40, 178-201, 233-37 (analyzing the problem and collecting studies); David J. Ravenscraft \& F.M. Scherer, Mergers, Sell-Offs, and EcoNOMIC EFFICIENCY 75-122 (1987) (showing profit declines after conglomerate acquisitions); Bernard S. Black, The Value of Institutional Investor Monitoring: The Empirical Evidence, 39 UCLA L. REV. 895, 898-917 (1992) (collecting studies suggesting suboptimality with respect to a variety of decisions by significant portions of the corporate population); Michael C. Jensen, The Modern Industrial Revolution, Exit, and the Failure of Internal Control Systems, 48 J. Fin. 831, 854-62 (1993) [hereinafter Jensen, The Modern Industrial Revolution] (presenting data that suggest the massive misuse of internally generated cash flows by a significant portion of major U.S. corporations); Michael C. Jensen, Agency Costs of Free Cash Flow, Corporate Finance, and Takeovers, 76 Am. Econ. Rev. (PAPERs \& Proc.) 323 (1986) (suggesting hostile takeovers and leverage as cures); Porter, supra note 18, at 67, 73 (arguing that even when U.S. capital funds go to investment outside the firm, such investment tends to be in short-term, readily valued acquisitions that slight needed investment in long-term "intangibles"). 
management focused on the impact of fiduciary duties on managerial incentives, but in the 1980s many shifted their attention to the effect of hostile takeovers on these incentives. Hostile takeovers, however, are themselves at best a blunt instrument for disciplining management; ${ }^{20}$ this is of particular concern because two of the other pressures that constrain managerial behavior - the managerial labor market and peer review - depend in important ways on the effectiveness of the takeover threat. ${ }^{21}$ With the decline in takeover activity in the 1990s following the collapse of the junk bond market and the widespread adoption of state antitakeover statutes that appear to pass constitutional muster, attention of corporate and securities lawyers has shifted again, this time to the last two

20. Information asymmetries between potential acquirers and incumbent management make a hostile tender offer inherently risky. For a bid to occur, the expected return from the acquisition must be sufficiently positive to compensate acquirers, who are risk averse, for this risk. This gives incumbent management room to behave suboptimally. See Fox, supra note 14, at 62-68, 84-91; Aaron S. Edlin \& Joseph E. Stiglitz, Ruining Rivals: Managerial Rent Seeking and Economic Inefficiencies (May 1992) (unpublished paper presented at Center for Economic Policy Research, on file with author). Gathering information to find suboptimally run firms is costly. If a potential acquirer conducts such a search, identifies a target, and announces an offer, others can join in the bidding. The possibility of such free riding on the first potential acquirer's search reduces the incentives for it to gather the information in the first place, and so the suboptimally run firm may never be a target. See id. (describing effects of information asymmetries on alternative management bids); see also Frank H. Easterbrook \& Daniel R. Fischel, The Proper Role of Target Management in Responding to a Tender Offer, 94 HARV. L. REv. 1161 (1981) (arguing, for this reason, against permitting target managers to implement defenses even to the extent necessary to create an auction). Empirical data suggests that the premiums that acquirers must pay average around $50 \%$. See Michael Bradley et al., Synergistic Gains from Corporate Acquisitions and Their Division Between the Stockholders of Target and Acquiring Firms, 21 J. FIN. ECON. 3 (1988). One explanation of this premium is that this is the average extent to which incumbent managers must underperform before triggering a takeover.

Reflecting on these kinds of considerations, Eugene Fama concludes, "[Henry] Manne's approach, in which the control of management relies primarily on the expensive mechanism of an outside takeover, offers little comfort [to those concerned with the incentive problems caused by the separation of share ownership and control]." Eugene F. Fama, Agency Problems and the Theory of the Firm, 88 J. PoL. ECON. 288, 295 (1980). Fama places reliance instead on the managerial labor market and peer review as the most effective pressures. Id.; see also Eugene F. Fama \& Michael C. Jensen, Separation of Ownership and Control, 26 J.L. \& ECON. 301 (1983).

21. The dependence of these pressures on the effectiveness of the takeover threat is not sufficiently recognized. Eugene Fama, who sees the managerial labor market and peer review as substitutes for the takeover mechanism, Fama, supra note 20 , fails to consider that these factors alone are unlikely to counteract the managerial deviation - retention of internally generated cash flow for suboptimal new investments and acquisitions - that both theoretical and empirical studies suggest is the most clearly significant. See supra note 19 and accompanying text. Absent a takeover threat effective enough to force the management teams running all of the economy's established corporations to have share-value maximization as their goal, these teams are likely to have goals that would lead to overretention any time that their firms have an insufficient number of quality investment possibilities relative to their internal cash flow. Thus, the entities that constitute the buyer's side of the market for managerial labor (these managerial teams) will not penalize the sellers (the individual managers) for engaging in overretention. The same comments apply to peer review. See Fox, supra note 14 , at $143-48$. 
sources of pressure on management incentives - shareholders and outside directors. The new interest is in what kinds of legal changes could give shareholders and outside directors the knowledge, power, and independence to be more effective monitors - better able to participate in setting agendas and to review managerial decisions in a meaningful way. ${ }^{22}$ Although improved monitoring can narrow the boundaries of managerial discretion in important ways, the inherent problems in steering large organizations means that the discretion that remains will inevitably be wide. Thus we need to be concerned as well with how shareholders and directors can use any increase in their power to establish incentives that are internal to the firm and that better motivate managers. Such incentives may also be useful to make outside directors themselves more effective monitors. ${ }^{23}$ Although such internal incentives have long been of interest to economists, scholars of corporate and securities law have to date given them scant attention. ${ }^{24}$

There are strong theoretical reasons to believe that it is good social policy to encourage practices that increase managerial wealth when share price increases. A manager faced with a choice between an action that would increase shareholder wealth and one that would not is more likely to choose the one that does if that choice would increase her personal wealth as well. This flows from the most fundamental proposition in economics - that people are rational maximizers of their own wealth. ${ }^{25}$ The efficient market hy-

22. See, e.g., Bernard S. Black, Shareholder Passivity Reexamined, 89 Mich. L. Rev. 520 (1990); Black, supra note 19; Bernard S. Black \& John C. Coffee, Jr., Hail Britannia?: Institutional Investor Behavior Under Limited Regulation, 92 Мich. L. Rev. 1997 (1994); John C. Coffee, Jr., Liquidity Versus Control: The Institutional Investor as Corporate Monitor, 91 Colum. L. Rev. 1277 (1991); Alfred F. Conard, Beyond Managerialism: Investor Capitalism?, 22 U. MICH. J.L. REF. 117 (1988); Ronald J. Gilson \& Reinier Kraakman, Reinventing the Outside Director: An Agenda for Institutional Investors, 43 Stan. L. Rev. 863 (1991); Mark J. Roe, A Political Theory of American Corporate Finance, 91 Colum. L. Rev. 10 (1991).

23. See Jensen, The Modern Industrial Revolution, supra note 19, at 862-65; Myron Scholes, Executive Compensation 4 (May 1, 1992) (materials presented at the Center for Economic Policy Research, on file with author).

24. One exception is the portion of the debate over insider trading prohibitions concerning the effect of insider trading on managerial incentives. See Henry G. Manne, Insider Trading AND the Stock MARKet 78 (1966). Other exceptions include Fox, supra note 6, at 277-90 (examining the effect of insider trading rules on share price accuracy); Merritt B. Fox, Shelf Registration, Integrated Disclosure, and Underwriter Due Diligence: An Economic Analysis, 70 VA. L. Rev. 1005, 1012-14, 1018-22 (1984) [hereinafter Fox, Shelf Registration] (describing how mandatory disclosure rules, through their influence on share price accuracy, affect the agency-cost-reducing effectiveness of the takeover threat and share-price-based compensation); Geoffrey S. Rehnert, Note, The Executive Compensation Contract: Creating Incentives to Reduce Agency Costs, 37 Stan. L. Rev. 1147 (1985) (proposing an executive compensation package designed to reduce agency costs).

25. See Richard A. Posner, Economic Analysis of Law § 1.1, at 3-4 (4th ed. 1992). 
pothesis in its broadly accepted "semistrong" form holds that share price is ordinarily the best available proxy for share value ${ }^{26}$ and hence for shareholder wealth. Thus forms of compensation whose return to the manager is favorably influenced by increases in share price, most prominently employee stock options (ESOs) and stock appreciation rights (SARs), ${ }^{27}$ are more likely to lead to decisions that maximize shareholder wealth. These forms of compensation, ceteris paribus, should be favored over others, and managerial share ownership should be encouraged. ${ }^{28}$

26. The efficient market hypothesis (EMH), most broadly stated, is that the market price of a security "fully reflects" all information publicly available at the time in question. Much has been written about the efficient market hypothesis. The seminal article reviewing the work that formed the basis for the hypothesis is Eugene F. Fama, Efficient Capital Markets: A Review of Theory and Empirical Work, 25 J. Fin. 383 (1970). An early statement of the theory in relatively nontechnical language is James H. Lorie et AL., The Stock Market: Theories AND Evidence 55-79 (2d ed. 1985). See also Ronald J. Gilson \& Reinier H. Kraakman, The Mechanisms of Market Efficiency, 70 VA. L. REV. 549 (1984). The "actual value" of a share is the future stream of income - dividends and other distributions accruing to its holder discounted to present value. The EMH suggests that market price is the best estimate of actual value that can be made based on publicly available information. For an elaboration of these concepts of fairness and actual value and their relationship to market price, see Fox, Shelf Registration, supra note 24, at 1010-14.

Share price's quality as a proxy for share value is not free from controversy. Even if the market is relatively efficient with respect to publicly available information in the sense that the ordinary investor cannot make money by trading on such information, the market may only be "speculatively efficient" (that is, prices are, conditional on such information, unbiased predictors of future financial returns) and not "allocatively efficient," (that is, they are not unbiased predictors of the discounted value of the future cash flows produced by the issuers' underlying real assets, the subject of "fundamental" information). Jeffrey N. Gordon \& Lewis A. Kornhauser, Efficient Markets, Costly Information, and Securities Research, 60 N.Y.U. L. Rev. 761, 825-30 (1985). Furthermore, some commentators dispute whether the market is efficient at all. They point to the existence of a large body of investors ("noise traders") influenced by "beliefs or sentiments . . . not fully justified by fundamental news" and to limitations on the ability of better informed, more rational investors to arbitrage away their influence on price. Andrei Shleifer \& Lawrence H. Summers, The Noise Trader Approach to Finance, J. ECON. PERSP., Spring 1990, at 19, 19-20 (offering a nontechnical overview of the "noise" theory approach); see also Fox, supra note 14, at 36-59, 81 app. 1.4. Even if share price is not as good a proxy for share value as the most loyal adherents of the EMH suggest, however, it may well not be possible to construct an institutional alternative that would be better than share-price-based compensation in relating compensation to true changes in share value.

27. Stock options and SARs have the feature that, for a given expected cost to the firm at the time of their award, the amount of reward ultimately received by the executive is particularly sensitive to differences in share performance. An employee stock option typically gives the manager the right, becoming effective at some point in the future, to purchase shares from the firm at the market price prevailing at the time the option is granted. If the firm performs well and its share price increases, the manager can exercise the option and immediately sell the shares for a profit. Stock appreciation rights work more simply: the manager is given the right, becoming effective at some point in the future, to receive from the firm the difference between the price of a share at the time the right is exercised and the price at the time the right is granted. In each case the timing of the exercise of the right once it has become effective is determined by the manager.

28. The importance of share-price-based compensation becomes clear in light of other methods. A straight contractual salary will have no effect on management decisions, because it is set in advance and does not vary with performance. The promise of year-end bonuses 
Share-price-influenced compensation and share ownership already play a very large role in the economic lives of top executives. A Conference Board survey on executive compensation showed that in $1992,82 \%$ of responding manufacturing firms had a stock plan for top executives, and that in 1991 their five highest-paid executives' median gains from exercising previously granted ESOs constituted $83 \%$ of their salary. ${ }^{29}$ The extent to which the structure of compensation for U.S. firms provides incentives to maximize share price is also indicated by the fact that there is a high positive correlation between changes in compensation and in share price. ${ }^{30}$

and future salary increases based on merit are devices by which top management as a group can reward those members who have made decisions contributing to the group's goals. Incentives awarded by a management group, however, will protect shareholders only if there is in turn a way to align the interests of the group with those of the shareholders. A profitsharing arrangement may work to align management and shareholder interests to some extent, but a defect in those plans is that "profit" is an accounting figure that at best captures only imprecisely many of the gains and losses experienced by a firm. Profit-sharing arrangements often create incentives to make decisions that emphasize a firm's short-run performance over its long-run performance. In contrast, when a manager, in choosing among alternative courses of action, chooses the one that most benefits the firm, that choice will on average have the most positive immediate effect on share price, even if the benefit will not be realized until some point in the future.

The importance for economic efficiency of managerial share ownership and share-pricebased compensation was first formalized by Jensen \& Meckling, supra note 16. See also Miron Stano, Executive Ownership Interests and Corporate Performance, 42 S. Econ. J. 272 (1975). Constructing an optimal incentive structure is complicated, however. The typical top manager arrives at that position with little wealth relative to the value of her corporation, so it is not practical for her to start owning outright a significant percentage of its shares. As noted above, stock options and SARs exercisable at the market price at time of issue are partial solutions, see supra text accompanying notes $26-27$, but their asymmetric payoffs can lead managers to be indifferent to downside risk. This problem can be mitigated, but at a price, by compensation in the form of "in the money" options or by a levered equity purchase plan. The share price of a corporation is influenced by many factors outside the control of management - these factors significantly add to the risk of share ownership and share-pricebased compensation. A partial solution here would be to grant managers rights or compensation based on share price as adjusted by such things as the performance of other firms in the corporation's industry and the stock market as a whole. For an examination of such problems, see Scholes, supra note 23. See also G. Bennett Stewart III, Remaking the Public Corporation from Within, HARv. Bus. Rev., July-Aug. 1990, at 126; Rehnert, supra note 24. Share price still has an important influence on the managerial wealth effect of all these schemes, however, and thus all present the potential to profit from inside information.

29. The Conference Board Report No. 1016, Top Executive Compensation: 1992 Edition 17 tbl. 13, 18 tbl. 20; see also David F. Larcker, The Association Between Performance Plan Adoption and Corporate Capital Investment, 5 J. Accr. \& Econ. 3, 8 tbl. 2 (1983) (showing that in 1979, 84 out of the top 100 corporations used stock options to reward executives and 65 used SARs).

30. See Robert T. Masson, Executive Motivations, Earnings, and Consequent Equity Performance, 79 J. PoL. ECON. 1278, 1289 (1971) (finding that firms that tied executive compensation to stock returns perform better than those that do not); Kevin J. Murphy, Corporate Performance and Managerial Remuneration: An Empirical Analysis, 7 J. ACCT. \& ECON. 7, 25-37 (1985) (showing a similar correlation for salary and bonus even before adding in ESOs and SARs). The fact that compensation is structured in a way that creates incentives for increasing shareholder wealth does not necessarily mean that it is the incentives that made the better-performing managers perform the way they did. Correlation does not establish causation. It is possible that the typical manager in the study was unaffected by the incentive 
Kevin Murphy, in a study covering 1964-1981, found that the average value of the share holdings of top executives among the sampled firms was about $\$ 4.7$ million in 1983 dollars, which represents approximately thirteen times their average annual salary and bonus during the period. ${ }^{31}$ Murphy grouped the yearly experiences of the sampled executives according to how well their firms performed in terms of shareholder returns. Executives whose firms for a given year were in the worst performing group - about $10 \%$ of the sample - saw the value of their personal share holdings fall an average of about $\$ 2.9$ million. ${ }^{32}$ Executives whose firms were in the best performing group - about $20 \%$ of the sample - saw the value of their personal share holdings increase by $\$ 2.3$ million. ${ }^{33}$ The annual change in the value of the shareholdings of executives in these two groups of firms was several times their annual salary and bonus. ${ }^{34}$ Wilbur Lewellen found that in a sample of top executives of top corporations, for eighteen of the twenty-four sampled years, changes in executive wealth from the dividends and capital gains from shareholdings in their own firms on average exceeded their salary and bonus, sometimes by as much as six- to eightfold. ${ }^{35}$

Available empirical evidence suggests that share-price-sensitive compensation does in fact motivate managers to increase shareholder wealth. Firms that structure their compensation plans in ways that put emphasis on share returns outperform firms that do not structure their compensation plans that way. ${ }^{36}$ Event studies

structure under which he worked but that the board, which at the beginning of his tenure was not sure of the manager's abilities, observed firm performance over time and then began paying him what he was worth. For an example of this kind of "learning" theory of compensation, see Milton Harris \& Bengt Holmstrom, A Theory of Wage Dynamics, 49 REv. Econ. STUD. 315 (1982).

31. Murphy, supra note 30 , at $26-27 \&$ tbl. 3 .

32. Id. at 27 tbl. 3.

33. Id.

34. Id. at 28 (three to five times); see also George J. Benston, The Self-Serving Management Hypothesis: Some Evidence, 7 J. AccT. \& Econ. 67, 75 tbl. 1 (1985) (noting that for the executives working at the firms that performed particularly well or particularly poorly $45 \%$ of the total sample - annual changes in their shareholdings averaged approximately five times the total of their salary bonus, fringe benefits, and profitsharing).

35. Wilbur G. Lewellen, The Ownership Income of Management 87-92 (1971).

36. Elizabeth Jenkins and Robert Seiler, who studied a sample of 40 public firms, found that over a five-year period ending in 1983, the shareholder wealth of firms with "long-term compensation schemes" - those with little or no bonus and with significant proportions of executive income derived from the exercise of SARs or ESOs - grew an average of $80 \%$, while the shareholder wealth of firms with "short-term compensation schemes" - those based primarily on current accounting measures and derived primarily from bonuses and with little income from exercising SARs or ESOs - grew an average of only $27 \%$. Elizabeth Jenkins \& Robert E. Seiler, The Impact of Executive Compensation Schemes upon the Level of Discretionary Expenditures and Growth in Stockholder Wealth, 17 J. Bus. FIN. \& Acct. 
show a positive stock market reaction to the announcement of longterm incentive plans - plans in which share price plays a large role $^{37}$ - which is consistent with a market belief that these plans increase shareholder wealth. ${ }^{38}$ Studies also show that there is a higher correlation between compensation and firm performance, as measured by multiple indices including shareholder returns, in firms in which a substantial number of nonmanagement shares are held by a single outside bloc. ${ }^{39}$ This fact also suggests that shareholders believe that share-price-related compensation motivates managers to increase shareholder wealth, because when shareholders have direct control over executive compensation, they more often choose a form of compensation related to share price performance. ${ }^{40}$

The available empirical evidence suggests as well that managers are in fact more motivated to maximize shareholder wealth when they own more of their firm's shares, at least up to the point at which the holdings are so large that they permit managerial entrenchment. ${ }^{41}$ An event study that examined the stock market re-

585, 589 (1990); see also Masson, supra note 30 (finding that stock of firms from three industries did better if executive compensation was closely tied to stock performance).

37. James A. Brickley et al., The Impact of Long-Range Managerial Compensation on Shareholder Wealth, 7 J. Accr. \& ECON. 115, 123-27 (1985) (reporting a positive reaction to an undifferentiated group of performance plans, some of which involved share-price-based units and some of which did not); Larcker, supra note 29, at 27-28 (same).

38. This reaction could be explained two other ways. One explanation is that executives tend to propose such plans when their private knowledge leads them to foresee a bright corporate future and that an announcement of such a plan is seen by the market as a signal of the existence of such positive information. The other explanation is that the plans reduce the total amount of taxes paid by the executives and the corporation, the corporation - directly, or indirectly through a compensation package with less of an expected payout to managers gets some of this benefit, and the market recognizes this. It would be extremely difficult to disentangle available data in a way that would separately test the incentive and signaling explanations, but there is at least some evidence that reduced taxes alone cannot fully explain the observed stock market reaction. See Ellen L. Pavlik \& Ahmed Belkaoui, DetermiNANTS OF Executive Compensation 22 (1991).

39. William A. McEachern, Management Control and Performance 77-84 (1975) (claiming that the existence of an outside bloc increases the correlation between compensation and accounting profits); Luis R. Gomez-Mejia et al., Managerial Control, Performance, and Executive Compensation, 30 ACAD. Mgmt. J. 51 (1987).

40. But see Gomez-Mejia et al., supra note 39, at 62 (testing the hypothesis that shareholder-controlled firms compensate management with long-term rewards like stock options more than other firms and failing to find statistically significant support).

41. See, e.g., John J. McConnell \& Henri Servaes, Additional Evidence on Equity Ownership and Corporate Value, 27 J. Fin. Econ. 595, 601 (1990) (finding that shareholder returns increase as insider stock ownership increases until such insider share reaches $40 \%$ to $50 \%$ ).

Most large public firms fall well short of the ideal range suggested by these results. Of the 1000 largest firms measured by market value, the median CEO owns only $0.2 \%$ of his firm's shares, and $75 \%$ own less than $1.2 \%$. Jensen, The Modern Industrial Revolution, supra note 19, at 864 (citing Kevin Murphy, Executive Compensation in Corporate America, 1992 (1992)). Of the top 250 firms, only one CEO in 10 owned at least $1 \%$ and fewer than 
action to an issuer's announcement that it intended to acquire another firm showed that the market reaction was more favorable the greater the percentage of management share ownership in the acquiring firm. ${ }^{42}$ This study suggests the market believes that when managers make important decisions, such as a decision to acquire another firm, they are more likely to make the choice that enhances shareholder wealth if they have substantial share holdings themselves.

A number of pressures are currently at work to increase both the portion of managerial and directorial compensation based on share price and the extent of managerial and directorial share ownership. Dramatic increases in both have been called for by prominent critics of U.S. managerial performance such as Michael Jensen and Kevin Murphy, who see insufficient incentives as a major cause of problems with U.S. corporate management. ${ }^{43}$ As manifested by the recent dismissals of the CEOs of a number of our largest firms, the influence of institutional investors and the independence of outside board members appear to be increasing. ${ }^{44}$ Some institutional investors are likely to use their growing influence to try these proposals. Institutional investors, politicians, and members of the press also complain that the level of managerial compensation is too high. ${ }^{45}$ Managers' most defensible response, as some of their advisers have suggested, is to increase the proportion of compensation based on share price. ${ }^{46}$ Finally, the 1993 tax changes create

one in 20 owned more than $5 \%$. Michael C. Jensen \& Kevin J. Murphy, CEO Incentives It's Not How Much You Pay, But How, Harv. Bus. Rev., May-June 1990, at 138, 141.

42. Wilbur Lewellen et al., Merger Decisions and Executive Stock Ownership in Acquiring Firms, 7 J. Acct. \& ECON. 209 (1985).

43. Jensen \& Murphy, supra note 41, at 141-42 (arguing for more compensation based on share performance, though seeing a complementary role for cash compensation to protect executives from stock fluctuations outsider their control); see also Jenkins \& Seiler, supra note 36, at 588-89 (finding that firms with "long-run compensation schemes" exhibited higher ratios of capital spending to sales and $R \& D$ spending to sales than firms with "short-run compensation schemes"). Concerning calls for share-price-based directorial compensation, see supra notes 25-28 and accompanying text.

44. See, e.g., Brett D. Fromson, American Express: Anatomy of a Coup, WASH. Post, Feb. 11, 1993, at A1; Doron P. Levin, Stempel Quits Job As Top G.M. Officer in Rift with Board, N.Y. Times, Oct. 27, 1992, at A1; Steve Lohr, Big Business in Turmoil: Upheavals at I.B.M., Sears and Elsewhere Underline Fundamental Shifts in Economy,, N.Y. TIMEs, Jan. 28, 1993, at A1; Steve Lohr, I.B.M. to Replace Its Top Executive, N.Y. TimEs, Jan. 27, 1993, at A1.

45. See, e.g., Leslie Wayne, Shareholder Advocate's New Target, N.Y. Times, May 10, 1993, at D1; 138 Cong. Rec. S2907-01 (daily ed. Mar. 5, 1992) (statement of Sen. Levin); Graef S. Crystal, Cracking the Tax Whip on C.E.O.'s, N.Y. Times, Sept. 23, 1990, § 6, pt. 2 (Business World Magazine), at 48.

46. See, e.g., Memorandum from M. Lipton, Attorney, Wachtell, Lipton, Rosen \& Katz, to clients (May 17, 1991) (on file with author) (calling for "a much greater proportion of executive compensation" to be based on long-term appreciation in the price of the corporation's stock). 
new inducements. The new law eliminates the corporate income tax deduction for top executive salaries in excess of $\$ 1$ million but creates an exception to that cap for certain share-price-based compensation. ${ }^{47}$ It also creates a significant difference between the marginal tax rate on the ordinary income of the highest-income individuals and the rate on capital gains - the same situation that prevailed before 1986 - again making qualified stock options a more attractive form of compensation for managers. ${ }^{48}$

\section{B. The Impact of Section 16(b) on Managerial Incentives}

Section 16(b) requires the return of profits from certain pairs of transactions involving equity securities. Pairs of transactions arguably regulable in this fashion include ordinary cash purchases and sales as well as transactions involving ESOs, SARs, and other share-price-based forms of compensation. The scope of section 16(b)'s coverage of these transactions is a question of statutory interpretation. Directors and officers have at least a sense of the current interpretation when they consider whether to purchase shares in the market and whether to accept a given portion of their total compensation in share-price-based form. The more potential transactions that a given interpretation would pair with a market purchase, the less attractive the purchase becomes. The more potential transactions involving ESOs, SARs, and other share-pricebased compensation devices a given interpretation would pair, the less attractive share-price-based compensation becomes. Thus, broader interpretations of section 16(b) are likely to result in managers owning a smaller percentage of their firms' shares and in a smaller portion of their compensation being in share-price-based form. To the extent that the transactions deterred by a broader interpretation would in fact have been based on inside information, the interpretation furthers the statutory purpose. To the extent that the deterred transactions would not have been so based, the

47. The cap exempts stock options with an exercise price equal to the fair market value of the shares at the time the option is granted if the options are granted pursuant to a plan approved by shareholders and a compensation committee of outside directors. Omnibus Budget Reconciliation Act of 1993, Pub. L. No. 103-66, § 13211(a), 107 Stat. 312, 470 (codified at I.R.C. § $162(\mathrm{~m})$ (West Supp. 1994)).

48. The marginal rate on ordinary income for the highest income individual has been increased to $39.6 \%$. Omnibus Budget Reconciliation Act of 1993, Pub. L. No. 103-66, $\S 13202(\mathrm{a})(1), 107$ Stat. 312, 461 (codified at I.R.C. § 1 (West Supp. 1994)). The capital gains rate remains at $28 \%$. I.R.C. $\S \S 1(\mathrm{~h}), 1222$ (West Supp. 1994). Executives pay no tax when granted a "qualified" incentive stock option. See I.R.C. §§ 421(a), 422 (Supp. III 1990). When the option is exercised, the gain realized between the exercise price and the then-fairmarket value is taxed at the capital gains rate, not at the ordinary income rate. See I.R.C. $\S 1221$ (1988). 
broader interpretation will instead simply weaken the agency-costreducing structure of management incentives.

The mere fact that a trade has been undertaken by an insider rather than an outsider significantly adds to the probability that the trade is based on inside information. Thus, the most thorough way for Congress to have stopped trades based on inside information would have been to prohibit officers and directors from engaging in any transactions involving their firm's shares or to impose a penalty that is the effective equivalent, requiring the return of all profits gained by insiders through the acquisition and sale of their firm's shares however long separated in time. Implicit in the decision not to take the route of total prohibition is a recognition by Congress that at some point the additional reduction in trades based on inside information would not be worth the cost in terms of reduced incentives. This decision also suggests an overall principle, to be developed further after the presentation of the model in Part II and an exploration of congressional intent in Part III, for deciding the appropriate reach of section 16(b). For some classes of paired transactions that are not clearly covered by the statute, adding the fact that one is followed by the other within six months to the fact that an insider was involved in no way increases the probability that one of them was based on inside information. To include these classes of transactions within the reach of the statute would be inconsistent with the intent of Congress, as reflected in its decision not to ban all insider transactions. For other classes of paired transactions that are not clearly within the reach of the statute, adding the fact that one is followed by the other within six months does increase the likelihood that one of them was based on inside information, an increase as great as adding that fact when the transactions involved are clearly covered ordinary cash for security purchases and sales. To fail to include these classes within the statute's reach would be inconsistent with the congressional purpose of fighting insider trading by penalizing short-swing transactions.

\section{A General Theory}

The two fundamental questions addressed by this article whether the general approach of section 16(b) is worthwhile and, if so, what classes of paired transactions the section should cover both require an approach for comparing the magnitude of the desired effect of section 16(b), which is the deterrence of transactions motivated by inside information, with the magnitude of its undesired effect, which is the deterrence of transactions motivated by 
any other cause. This comparison can be developed through a series of three models. The first model assumes a world in which all inside information is positive: negative information is immediately disclosed to the general public. The second model assumes a world in which all inside information is negative: positive information is immediately disclosed. The third, more complex model has both positive and negative inside information. Throughout, it will be assumed that no other constraints on insider trading exist.

All these models involve ordinary transactions clearly covered by the statute. Shares are purchased and sold for cash in an open market by a person who is an insider at the time of both transactions. There are no options available, but investors may sell short and may borrow in unlimited amounts. Thus transactions are possible that are sufficiently analogous to put and call options to permit the development of principles to deal with those transactions.

\section{A. A World With Only Positive Inside Information}

Assume a world in which all inside information is positive. In this world, some purchases by insiders would be based on inside information and some would not, but no sales by insiders would be based on inside information. The model of this world developed here will be used to consider three questions. First, if section 16(b) did not apply, how would we expect purchases based on inside information and purchases not so based to transpire, and, subsequently, what kind of sale behavior would we expect to be associated with each kind of purchase? Second, still assuming that section 16(b) did not apply, how accurate would it be to infer that inside information had been used in the purchase of an issuer share if that purchase were followed by a sale within a period of six months, and how accurate would it be to infer that inside information had not been used if such a purchase were not followed by a sale within six months? Third, how would the application of section 16(b) affect the purchase and sale behavior of an officer ${ }^{49}$ who, but for section 16(b), would surely have made a purchase not based on inside information (an "innocent" transaction), and how would it affect the behavior of the officer who, but for section 16(b), would surely have made a purchase based on inside information?

49. For convenience, the discussion will be in terms of transactions undertaken by officers, but it is equally applicable for ones undertaken by directors as well. 


\section{Purchase and Sale Behavior in the Absence of Section 16(b)}

a. Purchase behavior. How does a share purchase not based on inside information transpire compared to one based on such information? To answer this question, we will examine a scenario that starts with an officer who has had no information concerning the future prospects of the firm that has not been equally available to the investing public. The officer then receives inside information concerning an event that will increase the issuer's earnings. For simplicity, assume that the officer knows for certain that the event will occur and can determine its ultimate effect on the issuer's earnings and the value of the issuer's shares. Investment behavior in modern finance theory is discussed in terms of portfolio choice, and so our focus will be on the officer's portfolio before and after receipt of the inside information. The issuer shares in the officer's portfolio at the start of the scenario can be regarded as innocent purchases. The officer did not act on inside information in purchasing those shares. The increase in issuer shares contained in the officer's portfolio after receipt of the information represents shares purchased on the basis of inside information.

$i$. Portfolio choice theory as a predictor of behavior. The composition of the officer's portfolio at any given point in the scenario can be predicted through the application of portfolio choice theory.50 Portfolio choice theory in its standard exposition focuses on investment behavior in a single period. Whatever the investor does not plan to consume in this period, he invests. In the next period he consumes the results of these investments. The theory tells the investor how to compose a portfolio at the beginning of the investment period that will maximize the expected utility he will derive from the end-of-period value of his invested wealth - the means for his consumption the next period. The factors that determine whether an investor will purchase a security are his taste for risk, the current price of each available security, his beliefs concerning the expected end-of-period price of each security, and his beliefs concerning the variance and covariances of that expected end-ofperiod price with the end-of-period prices of other available securities. Portfolio choice theory can be used to predict the behavior of the officer in our scenario because we assume he is a rational maximizer of his expected utility and so will follow its dictates. We also assume that for the officer, as for most investors, wealth has declin-

50. This model was originally developed by William F. Sharpe. William F. Sharpe, $A$ Simplified Model for Portfolio Analysis, 9 MGMT. ScI. 277 (1963). For a nontechnical exposition of this model, see LORIE ET AL., supra note 26, at 108-31. 
ing marginal utility, and so he is risk averse. ${ }^{51}$ Therefore, if two portfolios differ in their level of risk, he will find the riskier one equally desirable only if it has a sufficiently higher expected return to compensate him for the disutility he associates with the greater risk. The standard exposition also assumes the availability of an asset with a certain rate of return equal to $r^{*}$ (the safe asset) and the unlimited availability of borrowed money at a cost also equal to $r^{*}$.

To construct his optimal portfolio, the officer's first step is to determine the proportions in which he should hold the available, risky securities. This determination is based on his beliefs concerning the expected returns, variances, and covariances of these securities. The object is to find the combination with the highest "extra return/risk ratio," that is, $x$, the amount by which, whatever number of dollars is invested in risky securities, the expected return of the resulting portfolio exceeds what it would have been if it had been invested entirely in the safe asset, divided by $y$, the standard deviation (the positive square root of the variance) of that portfolio. 52 The critical lesson of portfolio choice theory is that holding a diversified set of risky securities yields benefits. A portfolio consisting entirely of the security that itself has the highest extra return/risk ratio will not have as high a ratio as one that also includes other securities that have lower ratios. In fact, in the absence of transaction

51. Investors are typically assumed to be "risk averse," that is, they like expected return and dislike risk. Thus, for any given level of expected return, the lower a portfolio's risk is, the better. The assumption of risk aversion is in turn derived from an assumption that the investor will derive declining marginal utility from consuming his end-of-period wealth; that is, compared to the utility an officer gains from any given level of wealth, one dollar more adds less to his total utility than one dollar less subtracts from his total utility. This leads to risk aversion because compared to the expected utility from a given level of end-of-period wealth known with certainty, the chance of one dollar over that level does not compensate for an equal chance of one dollar under that level. Thus, in a choice between two portfolios with differing risks, the investor will choose the riskier one only if it has a sufficiently higher expected return to compensate him for the disutility he associates with the greater risk.

52. As a rational utility maximizer, the officer follows the prescriptions of portfolio choice theory depicted in figure 1: (1) he considers each possible combination of risky securities that can be purchased with $W_{o}$, his initial wealth, and calculates the expected return and variance from holding that combination; (2) he constructs a graph on which each of these combinations is represented by a point relating its expected return, $\bar{w}$, and standard deviation, $\sigma_{w}$, and from this determines the subset of these points constituting his Markowitz efficiency frontier (MEF); (3) he constructs a capital market line (CML) by drawing the line that passes through $\left(0,1+r^{*}\right)$ and is tangent to the MEF, designating the point of tangency as RP. Each point on his capital market line to the left of RP represents a portfolio in which some part of $W_{o}$ is invested in the risk-free asset, and the rest of $W_{o}$ is invested in risky assets in the same proportions to each other as they are in RP. Each point to the right of RP represents a portfolio in which all of $W_{o}$ and some amount of borrowed monies are invested in risky assets, again in the same proportions to each other as they are in RP. The slope of the CML is the "extra return/risk ratio," because the CML shows the rate at which the officer can trade off risk for return. 
costs, it is desirable to hold within the portfolio at least some of each available risky security because, unless a given security's returns are perfectly correlated with the returns of another security, its inclusion in the portfolio can help diversify or hedge against the risks associated with other securities.

The officer's second step is to decide, based on his tastes concerning expected return and risk, the total number of dollars he actually wishes to invest in risky securities. One investor might invest only a portion of his wealth in risky securities and the rest in the safe asset, while another, less risk-averse investor might invest all of his wealth plus a certain amount of borrowed money in risky securities. Whatever the total amount an investor's tastes lead him to invest in risky securities, however, they will be in the same proportions to each other, the ones that he calculated in the first step to result in a portfolio with the highest possible extra return/risk ratio. 53

ii. The initial portfolio prior to receipt of inside information. What can be said about the officer's initial portfolio, which contains the issuer shares purchased not on the basis of inside information? Because we do not know the officer's specific beliefs, we cannot provide a definitive description of his holdings. We do know, how-

FIGURE 1

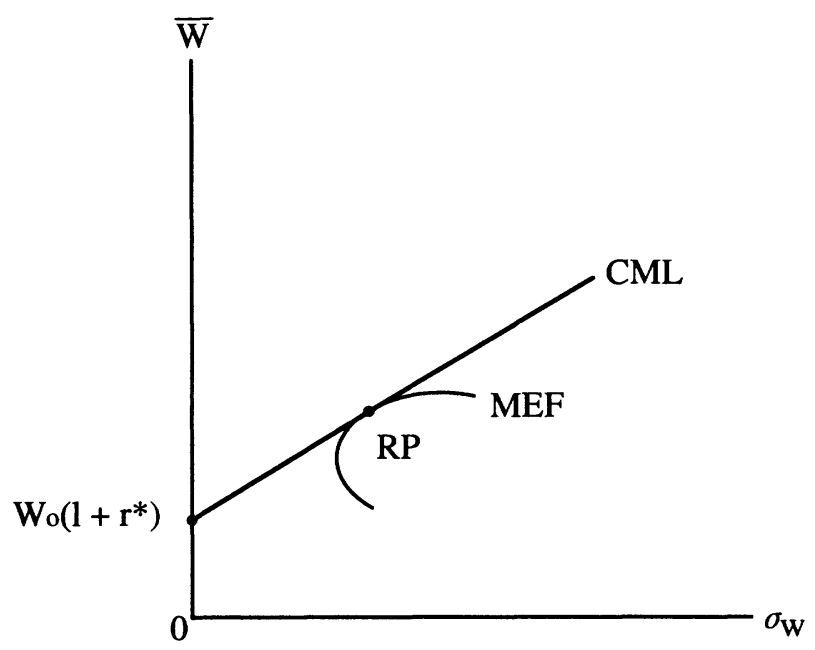

53. The officer chooses as his optimal portfolio the one point on the CML to which an indifference curve is just tangent. One possibility is depicted in figure 2 , in which the position of the officer's indifference curves is such that he chooses portfolio $O P^{\prime}$. If the officer is relatively less risk averse, his indifference curves would be differently shaped and he would choose a riskier, higher return portfolio such as $O P^{\prime \prime}$, as depicted in figure 3. 
ever, that he has no information concerning the issuer not available to the general investing public. We might assume, then, that he has the same beliefs as every other investor. This corresponds to the assumption of homogeneous expectations used in many finance theory models. In the absence of transaction costs, the officer in this scenario should hold each available risky security in the same proportion as will every other investor and hence in the same propor-

FIGURE 2

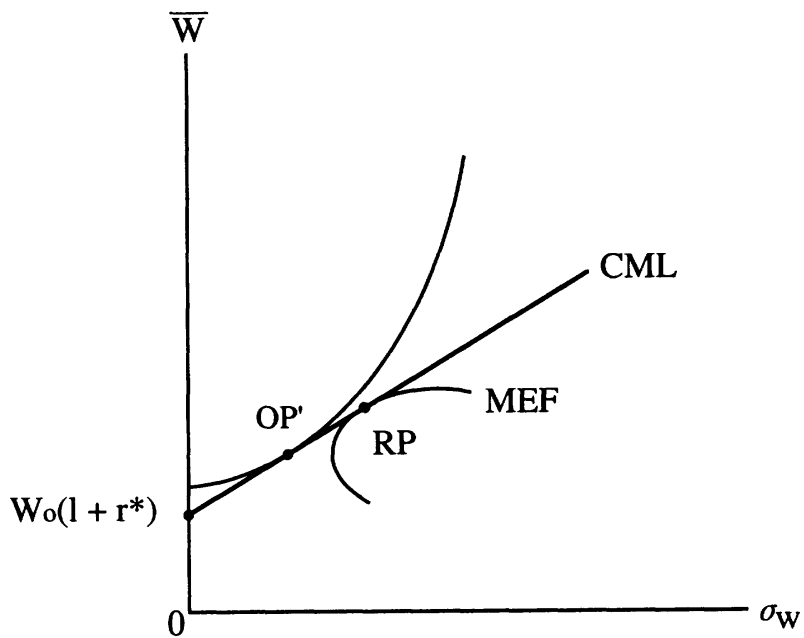

FIGURE 3

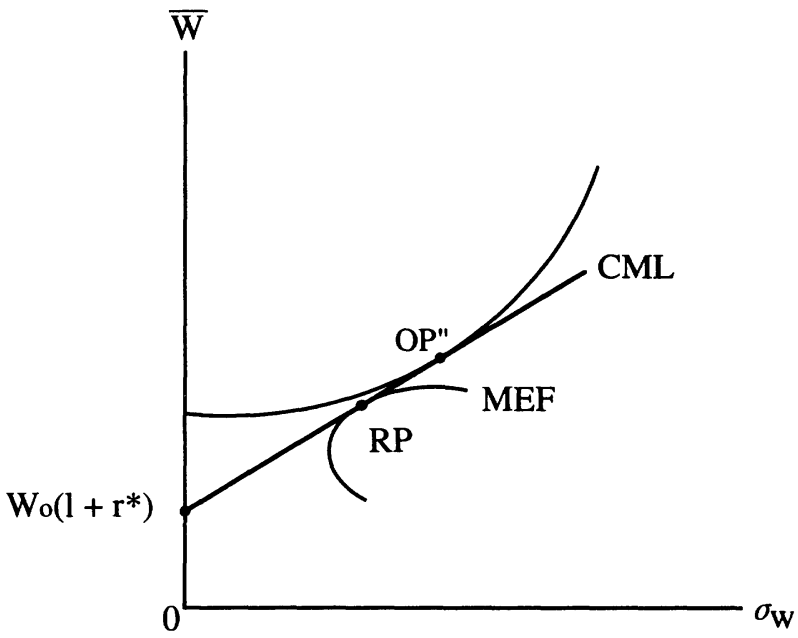


tions as they are outstanding in the market (the "market portfolio").

While the stylized version may not describe reality, it suggests that the officer is likely to hold the shares of the issuer long if he holds them at all because the information he possesses concerning the issuer is shared in common with all other investors. Such "firmspecific" information should play a large role in forming the beliefs of both the officer and the other investors concerning the expected value, variance, and covariances associated with the issuer shares.

Holding shares in the same proportions as the market portfolio is also consistent, absent transaction costs, with investment advice based on the semistrong statement of the efficient market hypothesis. The hypothesis is that securities prices adjust almost instantaneously to reflect any piece of information that becomes publicly available. ${ }^{54}$ This hypothesis suggests that an investor who does not possess inside information, like our officer at this point, cannot gain anything from choosing a portfolio in accordance with his beliefs. He will not be able to gather economically all the publicly available information relating to securities, so his beliefs will be based on partial information. Market prices will, on the other hand, reflect all such information. Instead of choosing a portfolio based on his beliefs, an officer that lacks undisclosed inside information about his firm should simply hold as diversified a portfolio as possible, which, absent transaction costs, is a portfolio with risky securities in the same proportions as the market portfolio. In the real world, unless the officer simply invests in an "index fund," transaction costs and the number of available securities are such that holding every security is impractical, but again, if the officer does hold shares of the issuer, he will hold them long. 55

54. See supra note 26.

55. The figures on the dollar value of the typical top executive's shareholdings of her firm show not only that these holdings are long term but also that they constitute a disproportionate share of her total portfolio. See supra notes 29-35 and accompanying text. Although the model assumes that in the absence of inside information she would hold her own firm's shares in the same proportion as the market portfolio, the fact that she typically holds much more in no way undercuts the model's conclusions. Whatever factors make the shares of her firm particularly desirable to hold - subsidized purchase programs, employer pressure, psychological identification with the firm, irrational optimism concerning the firm she knows best - portfolio choice theory will work in the same way as if she permanently viewed the expected return on these shares to be higher than others in the market. She will want to hold a larger proportion of her portfolio in her firm's shares than will others, but the extent to which she will wish to do so will still be limited by the portfolio-risk-reducing characteristics of holding other securities. Thus, at the margin she will be in the same position as if these factors were not present. 
iii. The portfolio after receipt of inside information. Now consider the next stage in the scenario: the officer comes into possession of inside information about an event that will increase the issuer's earnings. How will the officer adjust his portfolio in response to this information? This question cannot be answered by a direct application of the standard portfolio choice model because the model makes no provision for portfolio adjustments during the period of investment due to changes in the prices of securities or in the information possessed by the investor. To the extent that changed information is generally available to the public, this simplification in the portfolio choice model can be justified as consistent with the semistrong statement of the efficient market hypothesis. The almost instantaneous change in market price in response to changed information eliminates the possibility of gain that the investor would otherwise be able to enjoy by adjusting his portfolio in response to the information. In our scenario, however, the officer receives a change in information that is not generally available to the public, so the possibility of such a gain is not eliminated by an instantaneous corresponding change in the market price. The way to deal with the problem of maintaining the simplicity of the standard portfolio choice model while accounting for intraperiod trades motivated by nonpublic information is to assume that the portfolio as adjusted in response to the receipt of the inside information, whenever in the period it is actually received, is the same as the portfolio would have been if the information were received at the beginning of the period. In other words, the changes will correspond to the difference between the portfolio the investor actually constructed at the beginning of the period, when he did not have the information, and the one he would have constructed if he had possessed that information at the outset.

Receipt of inside information concerning an event that will increase the issuer's earnings will cause the officer to increase his evaluation of the expected end-of-period price of issuer shares. This change would prompt an investor to recalculate the optimal portfolio of risky securities, and it would call for an increase both in his proportional holdings of issuer shares ${ }^{56}$ relative to other available risky securities and in the absolute number ${ }^{57}$ of those shares A.

56. For a demonstration of this point in a world with two risky securities, see Appendix

57. The increase in the proportion of issuer shares in the officer's portfolio of risky securities does not lead automatically to the conclusion that there will be an absolute increase in the number of such shares. This is because the increase in expected wealth that arises from the acquisition of the positive information might in theory lead the officer to readjust to a 
that he holds. Thus, the officer's possession of the inside information will lead him to purchase more issuer shares for his portfolio than he would purchase in the absence of that information. These additional purchases can be said to be based on inside information.

The conclusion that receipt of positive inside information will lead an officer to purchase issuer shares seems obvious, but deriving that conclusion through portfolio choice theory reveals a point that is crucial for predicting how long the shares will be held: the purchase "dediversifies" the officer's portfolio of risky securities. The increase in the risky security portfolio's expected return is accompanied by an increase, though not as great, in its riskiness. This can be seen at an intuitive level by dividing the potential return that can be earned from an investment in a share of the issuer into two parts and, for a moment, thinking of the right to receive each part as a separate security. One security represents the right to receive the portion of the potential return that reflects the prospects of the firm without taking into account the inside information. The officer's evaluation of the risk and return characteristics of this first security are the same as his evaluation of the risk and return characteristics of the issuer shares prior to receipt of the inside informa-

less risky total portfolio by having a smaller portion of his initial wealth invested in risky securities. That is, he might invest more in the safe asset or, if he is leveraged, borrow less. If he did so, he would purchase greater security with his increase in expected wealth: the income effect of the change in value of issuer shares compared to price would dominate the substitution effect. Whether the officer would do so depends on the characteristics of his utility function relating his level of utility to his level of wealth, because a person's utility of wealth function determines how a maximizer of expected utility trades off expected wealth and risk.

Common, empirically supported assumptions concerning investor utility functions, however, suggest that this theoretical possibility is not real and that in fact the investor is likely to increase the riskiness of his portfolio. Finance economists commonly assume that investors have utility functions that, for relatively small changes in wealth, display constant absolute risk aversion; in other words, the ratio of the second derivative to the first is constant. The effect of this is that the investor's indifference curves relating expected end-of-period wealth to risk will have the same slope for any given amount of portfolio risk, whatever the level of his expected wealth. An increase in expected wealth will not lead him to want to "buy" more safety by trading more expected wealth for a given reduction in risk than before. For a portfolio theory proof of the assertion in the text that an increase in the expected extra return of an issuer's security, as would result from receipt of material nonpublic positive information, would lead an investor with a utility function displaying constant absolute risk aversion to increase the absolute number of the issuer's shares in his portfolio, see Merritt B. Fox, The Role of Finance in Industrial Organization: A General Theory and the Case of the Semiconductor Industry 445-47 (1980) (unpublished Ph.D. dissertation, Yale University).

The assumption that an officer has a constant absolute degree of risk aversion is in fact a conservative assumption. Finance economists commonly assume that for large changes in wealth, investors have utility functions that display declining absolute risk aversion. As wealth increases, investors are more willing to take chances and therefore are not willing to pay as much in reduced expected return in order to obtain a given reduction in risk. Thus, the increase in expected wealth from receipt of nonpublic material information may lead an officer to increase the total amount he invests in risky securities as well as the proportion devoted to the issuer's security. 
tion. The second security represents the increase in the potential return caused by the event that the inside information concerns. Because we have assumed for simplicity that the increase is certain, the second security has no risk. The price of the issuer's shares does not yet reflect the inside information, so possession of the inside information creates an opportunity to acquire the second security as a free bonus that accompanies the purchase of the first security. The number of issuer shares that the officer holds immediately prior to receipt of the inside information is the amount of the first security that he would optimally wish to hold given his evaluation of its risk and return characteristics. Receipt of the information causes the officer to acquire additional issuer shares in order to take advantage of the bonus. The result is that he holds more of the first security than he would wish to hold but for the fact that he must acquire more of the first security in order to acquire more of the second.

b. Sale of shares purchased on the basis of inside information. The last step in the scenario is that the information received by the officer ultimately becomes public, but before the end of the investment period. ${ }^{58}$ The efficient market hypothesis suggests that the price of issuer shares would increase at this point to reflect the information. What would we expect the officer to do with his portfolio? Again, we cannot answer this question by a direct application of the standard portfolio choice model. This time we maintain its simplicity and account for intraperiod adjustments by assuming that the portfolio the officer chooses to hold after the price change, whenever in the investment period the price change occurs, will be the same as the portfolio that the officer would have chosen at the beginning of the period if he and the public were both in possession of the information at that time and the issuer shares traded at the new price. Thus, we are dealing with the intraperiod portfolio adjustment resulting from the price change in an equivalent fashion to the way we dealt with intraperiod adjustment for new information, because the new price represents a higher opportunity cost for continuing to hold issuer shares.

The change in market price of issuer shares as a result of full dissemination of the information should equal the change, at the time the officer received the information, in his evaluation of the

58. We are only concerned with insider trading if public dissemination occurs before the end of the officer's investment period. Otherwise the officer will have gained nothing and the public lost nothing from the purchases based on the information, because the information will not be reflected in the end-of-period price. 
expected value of the end-of-period price of issuer shares, discounted to present value at $r *$ from the time of the price change to the end of the officer's investment period. This means that after the price change, the officer's evaluation of the extra return from continuing to hold an issuer share instead of selling it and investing the proceeds in the safe asset will be the same as his evaluation at the beginning of the period - prior both to his receiving the information and to the price change - of the extra return from purchasing an issuer share instead of investing an amount equal to the purchase price in the safe asset. The market price has caught up with the change in information that prompted the officer's purchase of extra shares and returned the officer to his original position. Thus at this third step in the scenario - the time at which the information becomes public - the officer will want to sell the same number of shares as he purchased at the second step - the time at which he received the information.

In essence, once the information becomes public, there is no reason for the officer to continue to hold the dediversified, riskier portfolio that he acquired when he received the inside information. The gain that he intended to reap from that adjustment can now be realized. If we again think of an investment in an issuer share as two securities, the return on the second security - the increase in the value of the shares because of the event the inside information concerns - has matured, so there is no longer any reason to continue to hold more of the first security than the officer would have wanted to all along but for the opportunity to acquire that increase for free. 59

\section{The Six-Month Rule of Inference}

What would be the efficacy of a rule of inference that all purchases followed by sales within a given time span, let us say the statutory six months, are purchases based on inside information, and all purchases followed by sales more separated in time are purchases not based on inside information? The answer to this question will depend on the length of time that inside information

59. To be technically correct, this description of the officer's sale behavior must be slightly modified. After the information becomes public, the officer will want to hold his issuer's shares in the same proportion to all other risky securities as he did before he received the information. The increase in his wealth, however, will mean that he will probably wish to own a larger absolute amount of risky securities than prior to receiving the information and so he would want to hold more of every security, including the issuer's, than he did at the beginning of the investment period. See supra note 57 . Thus he will probably not sell quite as many issuer shares as he bought at the time that he acquired the inside information. 
stays nonpublic and on the distribution of the lengths of the investment periods chosen by officers purchasing issuer shares without the benefit of inside information. The criteria by which to judge the rule of inference are its potential for Type I error - the likelihood of finding that an innocent purchase was based on inside information - and Type II error - the likelihood of finding a purchase based on inside information to be an innocent purchase. The rule of inference will be evaluated through an example based on a more general formula set out in the margin. The reader should remember that at this point in the analysis we continue to assume that there are no legal restraints on insider trading (including section 16(b)) and no sales based on inside information.

An officer who purchases issuer shares without relying on inside information presumably does so as part of an investment strategy to place his savings where they will grow so that he may enjoy greater consumption at the end of his investment period. Although this officer could continuously adjust his portfolio as new, publicly available information reaches him, the semistrong statement of the efficient market hypothesis, as noted earlier, ${ }^{60}$ suggests that such adjustments are not worthwhile. Thus, it is plausible to assume that an officer will hold his shares until he is ready to consume. The rate at which an officer will want to consume some or all of his investments will of course vary from one officer to another. Furthermore, as future consumption needs and desires are not completely predictable, any given officer may not in fact know at the time he purchases the issuer shares how long it will be before he will wish to sell them and consume the proceeds. It would be reasonable to assume that if we pooled all the shares purchased on a given day by officers of all public companies not acting on the basis of inside information, the pattern of sales of these shares over time would resemble a decay function: in each successive six-month time period a given percentage of the shares still held would be sold. For our example, assume that 500,000 shares are purchased on a given day and $20 \%$ sold in each succeeding six-month period. Thus 100,000 shares would be sold in the first six-month period leaving 400,000 still in officer portfolios; 80,000 would be sold in the next period leaving 320,000 still in officer portfolios; 64,000 would be sold in the period following that, and so on.

An officer that engages in a purchase of issuer shares based on inside information does so to profit from the reaction of the share

60. See supra text accompanying note 54 . 
price when the information becomes public and, as demonstrated above, will wish to sell the shares at that point even if he is not ready to consume the proceeds. Casual empiricism suggests that little inside information of a material nature stays secret for more than six months. The market imposes strong pressures on issuers to disclose internal information to the public. Timely disclosure is also prompted by securities law disclosure rules. And managers themselves have powerful incentives to breach confidentiality and to disclose valuable private information once they themselves have utilized it to purchase issuer shares because it is of value to others and because the sooner it is reflected in price, the sooner they can realize their profits. Certainly, few if any rule $10 \mathrm{~b}-5$ insider trading cases involve situations in which material inside information was kept secret for more than six months. Therefore, it would be reasonable to assume that if we pooled all the shares purchased on the basis of inside information on a given day by officers of all public companies, essentially all of them would, in the absence of legal restraints, be sold within six months. So, to continue the example, if 500,000 shares were purchased on the basis of inside information on the same day, all 500,000 would be sold within six months.

Now take these numbers and assume that they recur daily for a period of years so that a "steady state" pattern of purchases and sales occurs. Each day officers of public companies would engage in purchases of $1,000,000$ shares - 500,000 shares based on inside information and 500,000 shares not so based. Each day also in the steady state $1,000,000$ shares would be sold by officers of public companies. Of these, 500,000 would come from purchases made on the basis of inside information, all within the prior six months. The other 500,000 shares would come from purchases not made on the basis of inside information, 100,000 from purchases made within the prior six months, 80,000 from purchases made within the six-month period immediately preceding that, 64,000 from the six-month period before that, and so on. ${ }^{61}$ Thus 600,000 of the $1,000,000$ shares

61. Calculating the origins by period of the sales on a given day of shares purchased not on the basis of inside information is the mirror image of calculating the sales by period of shares purchased on a given day not on the basis of inside information. Let $V=$ the number of shares purchased each day not based on inside information, $b=$ the decay rate, and $c=(1$ b). If purchases began $k$ six-month periods preceding the day in question, sales on such day of shares so purchased will equal

$$
V \sum_{i=1}^{k}\left(c^{i-1}-c^{i}\right)=V\left(1-c^{k}\right)
$$

Because $0<c<1$, as $k \rightarrow \infty$ (the steady state), sales on such day of shares that were purchased not on the basis of inside information approach $V$. 
sold on any given day would have been purchased within the prior six months, 500,000 on the basis of inside information and 100,000 not on such basis. Consequently, a rule of inference requiring that any share purchased within six months prior to its date of sale be considered a purchase on the basis of inside information will have a $20 \%$ Type I error - that is, finding an innocent trade guilty - and a $0 \%$ Type II error - that is, finding a guilty trade innocent. Alternatively, thinking about the problem from a Bayesian perspective, adding the fact that a purchase was followed within six months by a sale to the fact that the purchase was by an insider increases the probability that it was based on inside information from $50 \%$ to $83 \% .{ }^{62}$

We can generalize from this example by considering a number of variations. If the decay rate for holdings of purchases not based on inside information were lower than $20 \%$ for each six-month period, the Type I error would be lower. If the decay rate were higher, the Type I error would be higher. If the respective proportions of innocent and guilty purchases were changed, the percentages of Type I and Type II error would be unaffected but the magnitude of whatever problems those errors create would be proportionally altered. ${ }^{63}$ In sum, over a wide range of plausible values for the parameters involved, Type I error will be relatively small, Type II error will be zero, and the fact that a purchase was followed

62. The Bayesian approach to probability involves looking at conditional probabilities and asking the question how much does a given fact add to the probability that an event has occurred. See Robert V. Hogg \& Allen T. Craig, Introduction to Mathematical STATISTICs $\$ 5.4$ (2d ed. 1965). The approach in essence consists of making probability assessments and reevaluating them in light of further information. See 1 BRUNO DE FINETTI, Theory of Probability § 4.6 (Antonio Machí \& Adrian Smith trans., 1974) (1970); Richard D. Friedman, $A$ Diagrammatic Approach to Evidence, 66 B.U. L. REV. 571, 586-88 (1986); David Kaye, The Law of Probability and the Law of the Land, 47 U. CHI. L. REv. 34, 49-50 \& n.54 (1979). In this case, the probability that a purchase was based on inside information given both that the purchaser was an officer of the issuer and that the purchaser sold within six months is $500,000 /(500,000+500,000)$, or $50 \%$, because we know that there are one million purchases by officers per day, of which 500,000 are motivated by inside information. The probability that a purchase was based on inside information given both that the purchaser was an officer and that the purchaser sold within six months is $500,000 /(500,000+$ $100,000)$, or $83 \%$, because we know that among all purchases of issuer shares by officers, 600,000 are sold within six months and 500,000 of those are based on inside information.

63. These points are evident from the following generalized formula. In a steady state, let $U=$ daily purchase of shares based on inside information; $V=$ daily purchase of shares not so based; $b=$ decay rate per six-month period of shares purchased not on the basis of inside information; $c=(1-b) ; P I_{i}=$ number of shares sold on a given day and purchased on the basis of inside information in the $i$ th six-month period preceding such day; and $P C_{t}=$ number of shares sold on a given day purchased not on the basis of inside information in the $i$ th sixmonth period preceding such day. Assume the shares purchased on the basis of inside information are sold within six months, so 
within six months by a sale will significantly increase the likelihood that it was based on inside information. ${ }^{64}$

\section{Purchase and Sale Behavior If Section 16(b) Is Applied}

What would happen to the scenario discussed above if section 16(b) applies to the officer and is fully enforced? How will this alter the officer's behavior in terms of transactions in issuer shares based on inside information and transactions not so based?

a. Shares not purchased on the basis of inside information. At the first stage of the scenario, the officer composes his initial portfolio prior to receiving any inside information. Therefore, the issuer shares in this initial portfolio are, as before, the result of purchases not based on inside information. The officer knows, however, when he constructs this portfolio that if he sells any issuer shares within six months, he will be forced under the statute to disgorge any profit from the sale. This rule forces him to consider whether, as seems likely, there is at least some possibility that he would wish to sell all or part of his portfolio within six months in order to consume. The officer may at the time of purchase plan for certain to consume some portion of his invested savings within six months, or

$$
\begin{gathered}
\sum_{i=1}^{\infty} P I_{i}=U . \\
\text { so } \quad P C_{i}=V\left(c^{i-l}-c^{i}\right), \\
\text { and } \quad P C_{l}=V(1-c)=V b \\
\sum_{i=1}^{\infty} P C_{i}=V \sum_{i=1}^{\infty}\left(c^{i-1}-c^{i}\right)=V .
\end{gathered}
$$

For a rule of inference that all shares sold on a given day purchased within the preceding six months are based on inside information, Type I error equals

$$
P C_{1} / \sum_{i=1}^{\infty} P C_{i}=V b / V=b \text {. }
$$

Type II error equals zero.

64. We are examining the power of a rule of inference based on the statutory six-month period. It is interesting to note, however, that if the length of the period involved in the presumption were made longer than six months, the Type I error would increase without a corresponding decrease in Type II error, which is already zero. The most extreme lengthening of the period - to infinity - would be equivalent to assuming that all purchases by officers are based on inside information, in which case Type I error would rise from $20 \%$ to $100 \%$. If we shortened the period involved in the presumption to less than six months, we would reduce Type I error below $20 \%$. Whether it would increase Type II error and, if so, by how much, depends on the distribution of the time periods for which inside information remains nonpublic. This analysis thus suggests the nature of the trade-offs involved in, and the empirical information needed to evaluate, the recommendation to amend $\S 16(\mathrm{~b})$ to reduce the statutory period to three months made by the American Bar Association Committee on Federal Regulation of Securities. See Committee on Fed. Reg. of Sec., supra note 9, at 1130-31. 
he may simply foresee that some emergency or special consumption opportunity might arise during that period.

The officer is likely to foresee at least a small possibility that his consumption needs will be great enough within six months that he would need to sell more of his investing than are represented by all of his holdings other than his issuer shares. If he does, the existence of the statute will lower the expected return he associates with issuer shares. Under those circumstances, he will have to sell his issuer shares and face the statute's direct effects. The best he can do - a zero return - is less than he would earn on an investment in the safe asset. There is, as well, the usual risk that the price of issuer shares at the time of sale will be less than the initial price.

The officer is likely to foresee a more significant possibility that he will want to sell some smaller portion of his portfolio in the next six months. Unless the officer's consumption needs exceed the value of his savings that are represented by all his holdings other than issuer shares, the officer could meet his consumption needs without selling any issuer shares. Under those circumstances, he would be able to avoid the direct effect of section 16(b) on his issuer shares, but he would be doing so at the cost of dediversifying his portfolio. Optimally, if he sells part of his portfolio to consume, he should continue to hold risky securities in the same proportions in his new, smaller portfolio as they were in his initial portfolio. But he cannot follow that optimal course of action if he needs to retain issuer shares to avoid the direct effect of section 16(b).

The conclusion is that the statute reduces the number of issuer shares that the officer will want in his initial portfolio even though he possesses no inside information at that time. The officer will know when he considers how many issuer shares to purchase that there is a possibility that he will have to give up any profits he makes and that, even if he can avoid giving up his profits, the issuer shares may turn out to be a dediversifying burden on his portfolio. Both prospects make issuer shares less attractive relative to other available risky securities than they would be if section 16(b) did not apply.

b. Purchases based on inside information. In the next stage of the scenario, the officer comes into possession of inside information that concerns an event that will increase the issuer's earnings. We saw above that the officer, in the absence of section 16(b), would adjust his portfolio in response to this information in a way that would increase his holdings of issuer securities, and that these purchases can be said to be based on inside information. The question here is the effect of section $16(\mathrm{~b})$ on these adjustments: Will it 
deter insider trading? To answer this question, we have to examine how section 16(b) alters an officer's expectation about the circumstances under which he can sell the shares he is considering purchasing on the basis of inside information. If the officer did not have to worry about section $16(\mathrm{~b})$, he would want to sell the shares he purchased on the basis of inside information as soon as the information became public, because if the officer continues to hold on to these shares after that point, he would leave his portfolio needlessly dediversified. Almost all material inside information, it was suggested, ${ }^{65}$ becomes public in less than six months. The statute will force the officer to remain with a riskier, dediversified portfolio for the period between public dissemination of the inside information and a date six months after the purchase date. ${ }^{66}$ The statute thus makes the purchase of issuer securities on the basis of inside information less attractive because the more shares that are purchased, the more dediversified the investor will be during this period. ${ }^{67}$ As a consequence the officer will purchase fewer shares in response to the receipt of the information.

c. Comparison of effects. This analysis shows that section 16(b) discourages both purchases of issuer shares based on inside information and purchases not based on inside information. The first effect is good: it is what the statute is supposed to accomplish. The second effect is bad: it discourages agency-cost-reducing managerial share ownership. A comparison of the statute's two effects runs along the same lines as the discussion above concerning the timing of purchase and sale as a rule of inference. ${ }^{68}$

65. See supra text accompanying notes $60-61$.

66. The sting of this forced dediversification is softened somewhat by the fact that the statute imposes its penalty only if the sale price is above the initial purchase price. Thus, if notwithstanding the positive price effect of the public announcement of the inside information and the ordinary prospects of capital appreciation, enough negative events transpire after purchase to result in a price equal to or below the initial purchase price, the officer is free to rediversify his portfolio without penalty.

On the other hand, the officer may also foresee the possibility that his consumption needs would be great enough within six months of the guilty purchase that he would need to sell more of his invested savings than are represented by all of his holdings other than his issuer shares. If this is the case, the officer faces the possibility that he would not be able to escape the direct effect of the statute, and the expected return he associates with the purchase would be lower.

67. The assumption here is that events further in the future are more difficult to predict with accuracy than events nearer in the future, so that both individual share prices and the price of the market portfolio vary more over longer periods of time than shorter ones. $\mathrm{Be}$ cause diversification is the way that investors cope with risk, longer periods of dediversification are less desirable.

68. See supra section II.A.2. 
Consider all the shares officers would purchase in their respective firms in the absence of section 16(b) on a given day. Officers would wish to sell within six months all the shares purchased on inside information but only some portion, in the example above, $20 \%, 69$ of the innocently purchased shares. Thus the costs of evading section 16(b) are on average more likely, in our example five times more likely, to burden a potential share purchase based on inside information than a potential share purchase not so based.

\section{Conclusion}

The model developed here for analyzing how section 16(b) affects insider trading has important implications for determining whether section 16(b)'s general approach is worthwhile. On the one hand, the model shows that, contrary to the hopes expressed in legislative history and in many judicial opinions, section 16(b) will not eliminate much insider trading by "taking the profit out of it"70 because the direct effect of the statute can easily be avoided most of the time. Historically, prior to the enactment of the statute, most officer and director purchases based on positive inside information probably were followed by sales within six months, as Congress believed and the model predicts. But the statute's very enactment made a continuation of this pattern unlikely.

On the other hand, the commentators who note the ease with which the direct effects of the statute can be evaded and conclude that the general approach of the statute is not worthwhile ${ }^{71}$ are also wrong. The maneuvers necessary to avoid the direct effect of section 16(b) bring their own costs. Officers who engage in insider trading must remain dediversified for longer than they would otherwise wish; thus section 16(b) will reduce, though not eliminate, insider trading. Furthermore, the reduction may be more substantial than it first appears. The most tempting situation in the absence of $16(\mathrm{~b})$ is where the insider knows a "sure thing" that will be announced very soon. The officer will have a strong incentive to purchase a large number of issuer shares, relative to his existing

69. See supra text accompanying note 60 .

70. Judge Clark, in the seminal case interpreting $\S 16(\mathrm{~b})$, Smolowe v. Delendo Corp., 136 F.2d 231 (2d Cir.), cert. denied, 320 U.S. 751 (1943), expressed such hopes:

We must suppose that the statute was intended to be thoroughgoing, to squeeze all possible profits out of stock transactions, and thus to establish a standard so high as to prevent any conflict between the selfish interest of a fiduciary officer, director, or stockholder and the faithful performance of his duty.

136 F.2d at 239.

71. See supra note 12 . 
holdings of securities, financed either by a sale of much of these holdings or by extensive borrowing. While such extensive purchases will make his portfolio much more risky until the public announcement and rediversifying sale of the purchased securities, the period of heightened risk is short and the expected reward is great. With the imposition of section 16(b), however, purchases of this magnitude would leave the officer in this highly risky position for a full six months. As a result, the officer will scale down considerably, though not eliminate, his insider trading.

\section{B. A World With Only Negative Inside Information}

In contrast to the first scenario, now assume a world in which all inside information is negative rather than positive. In this world, some sales by insiders would be based on inside information and some would not, but no purchases by insiders would be based on inside information. We can ask the same questions about this world as we did about the world in which all inside information was positive.

\section{Purchase and Sale Behavior If Section 16(b) Is Not Applied}

How does a share sale not based on inside information transpire compared to one that is based on inside information? Consider a scenario that again starts with the officer not having any undisclosed, inside information concerning the prospects of the firm. His portfolio at this stage is therefore the same as in the first stage of the scenario relating to positive information. ${ }^{72}$

The scenario can then develop in two ways. One way is for the officer to come to the end of his investment period never having acquired any inside information and to sell his issuer shares in order to consume. Such a sale is one not based on inside information.

The other possibility is for the officer to acquire negative inside information prior to the end of his investment period. How will the officer adjust his portfolio in response to this information? Again, to maintain the simplicity of the standard portfolio choice model while accounting for intraperiod adjustments, we will assume that regardless of when in the period the information is received, the adjusted portfolio will be the same as the portfolio would have been if the officer had known the information at the beginning of the period. The analysis exactly parallels that relating to the receipt of positive information. Receipt of the negative information will

72. See supra section II.A.1.a.ii. 
cause the officer to decrease his evaluation of the expected end-ofperiod price of issuer shares. He will therefore recalculate the optimal portfolio of risky securities, and this recalculation will cause him to decrease both the proportional holdings of issuer shares and the absolute number of issuer shares he holds. Thus receipt of the information will lead the officer to sell shares of the issuer, and such sales can be said to be based on inside information.

At the last stage in the scenario, the inside information received by the officer becomes public. ${ }^{73}$ Again the analysis parallels that for positive information. The change in the market price of issuer shares should equal the change in the officer's evaluation of the end-of-period price of issuer shares at the time he receives the information, discounting at $r^{*}$ to reflect the time value of money. Thus he will want to buy the same number of issuer shares as he sold when he received the information. In essence, the officer sold issuer shares solely in order to avoid the fall in market price that would accompany disclosure of the inside information. After the fall has occurred, he no longer has any reason to maintain reduced or negative holdings of issuer shares.

\section{The Six-Month Rule of Inference}

For a world in which only sales can be based on inside information, the statute suggests two possible rules of inference related to the timing of purchases and sales. The first possible rule of inference would be that all sales following purchases by less than six months are sales based on inside information, and all other sales are innocent. The second rule of inference would consider all sales followed by purchases within six months to be sales based on inside information and all other sales to be innocent. ${ }^{74}$ Again, the criteria by which to judge each of these rules of inference is its potential for Type I and Type II error. The rules will be evaluated in terms of an example that is based on a more general formula set out in the margin.

73. Again, we are not concerned with the situation in which the investor's investment period ends before the information becomes public. In that situation, even if he accelerates his sale of issuer shares to the time he receives the information, he gains nothing from having received and acted on it.

74. This second rule of inference could have been considered as well in the preceding discussion of the world with only positive inside information, but that would have added unnecessary complication at that stage in the analysis. Consideration of the rule at that stage would parallel the consideration here of the first rule of inference in a world with only negative inside information. 
a. Sale preceded by purchase. To evaluate the first rule of inference, which relates to a sale preceded within six months by a purchase, suppose that officers of all public companies purchase in aggregate 500,000 shares of their respective issuers' shares on a given day, not including any rediversifying repurchases to replace shares sold on the basis of inside information. According to our assumptions in this section, none of these 500,000 purchases are based on inside information. If there were no sales based on inside information, the pattern of sales might be as in our earlier example, a decay function in which officers would sell $20 \%$ of their issuer shares in each successive six-month time period. But in fact sales are made on the basis of inside information and the number of such sales will be a function of the proportion of officers that receive inside information, the significance of that information, and the number of issuer shares held by officers of public companies. Suppose that the proportion of officers and the significance of the average bit of inside information is such that, in the aggregate, officers receiving inside information in each successive six-month period sell $10 \%$ of the total number of issuer shares currently held by officers of public companies. ${ }^{75}$ There is no reason why an officer who purchased his shares in a recent period would be more likely to receive inside information than an officer who purchased his shares in a much earlier period. For expositional purposes, assume that sales, whether they are based on inside information or not, occur only on six-month anniversaries of the purchase date. Thus, at the end of the first six-month period - at the first six-month anniversary of the date of purchase of the 500,000 shares $-100,000$ shares will be sold not on the basis of inside information $(20 \%$ of the $500,000)$ and 40,000 shares will be sold on the basis of inside information ( $10 \%$ of the remaining 400,000 , which would otherwise not have been sold at that time). Officers selling the 40,000 will repurchase them within six months when the information becomes public. At the end of the second period, 80,000 shares will be sold not on the basis of inside information ( $20 \%$ of the remaining 400,000

75. Not included in the calculation of sales based on inside information are shares sold when an officer comes into possession of inside information but which would in any case have been sold to generate funds for consumption prior to the information becoming public. In such a situation, the officer has gained nothing from the early sale because the price had not declined by the point at which he would have sold if he had not received the information. At the time of the sale, the officer may not know for certain either when he would sell for consumption purposes or when the information would become public, but as long as he has rational expectations concerning these matters, the foregoing calculation of sales based on inside information should be an accurate representation of the aggregate impact of the use of the information on the market. 
remaining original shares and repurchase replacements) and 32,000 will be sold based on inside information (at this point there are 320,000 remaining original shares and repurchase replacements that otherwise would not have been sold at the time). At the end of the third six-month period, there would be sales of 64,000 not based on inside information and sales of 25,600 based on inside information, and so on. ${ }^{76}$

Now, as in the earlier example, take these numbers and assume that they recur daily for many years so that a "steady state" pattern of purchases and sales occur. Each day 500,000 shares are purchased, not counting replacement repurchases. As just described, they or their replacements are gradually sold not on the basis of inside information. Also, there will be selling on the basis of inside information from the accumulated stock of officer-held shares. As the sales pattern approaches a steady state, the origins of these sales on any given day are simply the decay functions detailed just above but in reverse: from original purchases made six months before, 40,000 based on inside information and 100,000 not so based; from original purchases twelve months before, 32,000 and 80,000 respectively; from original purchases in the period before that, 25,600 and 64,000 respectively, and so on. ${ }^{77}$ Because this is an infinite algebraic series, we can calculate for the steady state the total number of shares sold every day on the basis of inside infor-

76. The general formula for the progression of sales in successive six-month periods from shares purchased on a given day is as follows. Let $Z=$ the number of shares purchased by officers of public companies on a given day (in the example in the text, 500,000); $a=$ the proportion of such shares or repurchase replacements thereof held during any successive sixmonth period that are sold on the last day of such period not on the basis of inside information $(a=.20$ in the example); $b=$ the proportion of such shares or repurchase replacements thereof held during any given successive six-month period and sold on the last day of such period on the basis of inside information ( $b=.10$ in the example); $f=1-a(f=.8$ in the example); $S C_{i}=$ the number of shares sold in period $i$ not on the basis of inside information; $S I_{i}=$ the number of shares sold in period $i$ on the basis of inside information; and $S_{i}=S I_{i}+$ $S C_{i}$. Thus,

$$
\begin{gathered}
S C_{i}=Z\left(f^{i-1}-f^{i}\right)=Z(1-f) f^{i-1}=Z a f^{1-1} ; \\
S I_{i}=Z b f^{i}=Z b f f^{t^{-1}} ; \\
S_{i}=(Z a+Z b f) f^{i-1}
\end{gathered}
$$

77. The general formula for the original purchase dates, in terms of prior six-month periods, for sales of shares sold on a given day is as follows. Let $P S C_{i}=$ the number of shares sold on a given day not on the basis of inside information and purchased in the $i$ th six-month period preceding the sale date; $P S I_{i}=$ the number of shares sold on such day on the basis of inside information and purchased in the $i$ th six-month period preceding the sale date; and $P S_{i}$ $=P S I_{i}+P S C_{i}$. Because the origins of sales are just the mirror image of the sales of a purchase on given day, $P S C_{i}=Z a f^{i-1}, P S I_{i}=Z b f^{i}$, and $P S_{i}=(Z a+Z b f) f^{i-1}$. See supra note 76. 
mation, which in the steady state is 200,000 , and the number that are not, which is $500,000 .{ }^{78}$

The critical date in a portfolio theory explanation of behavior is a share's "original" date of purchase, and the discussion so far has been cast in terms of that date. We have assumed that if any share represents a rediversifying replacement for a share previously sold on the basis of negative inside information, that share is deemed to have the purchase date of the original share that it replaces. Although it could not be implemented as a practical matter, it is a useful first step to ask how good would be the rule of inference that considers the sale of a share originally purchased less than six months earlier to be based on inside information and the sale of a share originally purchased further in the past to be "innocent." The answer is not very good at all: such a rule would have a $20 \%$ $(100,000 / 500,000)$ Type I error (finding an innocent sale guilty) and

78. Assume $Z$ shares are purchased each day and are sold, as described above, on the sixmonth anniversaries of the original purchase date. If purchases began $k$ six-month periods prior to the sale date in question, the aggregate sales on such day not based on inside information will equal

$$
Z\left(\sum_{i=1}^{k}\left(f^{i-1}-f^{i}\right)\right)=Z\left(1-f^{k}\right)
$$

Because $0<f<1$, as $k \rightarrow \infty$ (the steady state), sales on such day approach $Z$. Approaching the problem of describing the steady state another way,

(1) $f=1 /(1 / f)=1 /(1 /(1-a))=\frac{1}{1+\frac{a}{1-a}}=\frac{1}{1+\frac{a}{f}}$

(2) $\sum_{i=1}^{\infty} f^{i-1}=1+\sum_{j=1}^{\infty} f^{j-1}=1+\sum_{j=1}^{\infty} 1 /\left(1+\frac{a}{f}\right)^{j}=1+\frac{f}{a}$

Let

$$
I=\sum_{i=1}^{\infty} P S I_{i}
$$

(the total number of shares sold on the basis of inside information on a given day)

and

$$
C=\sum_{i=1}^{\infty} P S C_{i}
$$

(the total number of shares sold not on the basis of inside information on a given day).

$$
\begin{gathered}
C=a Z \sum_{i=1}^{\infty} f^{i-1}=a Z(1+f / a)=Z(a+f)=Z \\
I=b Z f \sum_{i=1}^{\infty}=b Z f(1+f / a) .
\end{gathered}
$$


an $80 \%(160,000 / 200,000)$ Type II error (finding a guilty sale innocent). ${ }^{79}$

The apparent lack of probity of this rule of inference is not an artifact of the particular parameters chosen here; it can be demonstrated as well by the fact that if we selected at random without reference to their original purchase date 140,000 of the sales on a given day - the same number as were purchased in the immediately preceding six months - and simply assumed that these sales were based on inside information and that all the others were not, we would get the same Type I and Type II errors. This is because if we look at innocent and guilty sales on a given day in terms of their original purchase dates, each six-month period contributes to the two categories of sales in the same ratio. ${ }^{80}$ To know whether a share sold today was originally purchased in the most recent sixmonth period or one long ago tells one nothing about the chances that the sale was based on inside information. Adding the fact that $a$ share sold today was purchased in the most recent six-month period to the fact that it was sold by an insider does not increase one iota the likelihood that the sale was based on inside information.

This picture is not materially changed if we substitute the observable, actual purchase date in the rule of inference, that is, if we count all purchases within the last six months as original purchases even though we know that some of them represent replacement purchases. We know that any sale based on inside information will be replaced within the next six months. To see what effect this has, let us return to our steady state example, ${ }^{81}$ where we looked at sales on a given day, say January 14, 1994, that were the result of original purchases made on dates at six-month intervals going way back in

79. Applying the formula $P S C_{t}=Z a f^{t-l}$, the number of shares sold innocently that were originally purchased at the beginning of the six-month period just ending equals $Z a$. Thus,

$$
\text { Type I error }=Z a / C=Z a / Z=a
$$

Similarly, the number of shares sold on the basis of inside information and originally purchased at the beginning of the six-month period equals

$$
Z b f f^{i-1}=Z b f \text {. }
$$

Hence, the number so purchased more than six months before equals

$$
\begin{aligned}
& Z b f \sum_{i=1}^{\infty} f^{t-1}-Z b f=Z b f\left(1-\sum_{i=1}^{\infty} f^{i-1}\right)=Z b f(f / a) \\
& \text { Type II error }=\frac{Z b f(f / a)}{I}=\frac{Z b f(f / a)}{Z b f(1+f / a)}=\frac{(f / a)}{1+(f / a)}
\end{aligned}
$$

80. From supra note 77, for any given period of origin $i, P S I_{i}=Z b f^{i}$ and $P S C_{i}=Z a f^{i-1}$, and so $P S I_{i} / P S C_{i}=b f / a$.

81. See supra text accompanying notes 75-79. 
time. Consider the total purchases made on January 14, 1993: 500,000 shares. Of these, 100,000 were sold before January 14, 1994, not on the basis of inside information. On January 14, 1994, the sale date on which we are focusing, an additional 80,000 shares with an original purchase date of January 14, 1993, will be sold not on the basis of inside information, as well as an additional 32,000 shares whose sales are based on inside information. Between July 14,1993 , and January 14, 1994, the 40,000 shares sold based on inside information on July 14, 1993, will be repurchased. Thus, immediately prior to January 14,1994 , insiders would hold 400,000 shares with original purchase dates of January 14, 1993; 360,000 would be original shares, and 40,000 replacement shares. The 40,000 replacements ought to be spread proportionately among the 80,000 to be sold that day not based on inside information, the 32,000 to be sold based on inside information, and the 328,000 that are retained. Thus of the 80,000 innocent sales with an original purchase date of January 14, 1993, 8000 will have repurchase dates within the last six months; similarly, 3200 of the inside information sales will have such repurchase dates. For shares with an original purchase date of July 14, 1992, and sold on January 14, 1994, the comparable figures would be 6400 and 2540 , and so on. In aggregate, stretching back to infinity, 40,000 innocent January 14, 1994, sales will have repurchase dates within the preceding six months and 16,000 guilty trades will. Thus the rule of inference that a sale preceded by a purchase, whether original or repurchase, within six months is based on inside information and all others are not will have a Type I error of $27 \%$ $(140,000 / 500,000)$ and a Type II error of $72 \%(144,000 / 200,000)$.

$b$. Sale followed by purchase. The second possible rule of inference suggested by the statute is that only sales followed by purchases within six months should be considered sales based on inside information. Consider again a steady state in which officers of public companies in the aggregate purchase daily 500,000 shares of their respective issuers' shares, not including replacement repurchases, and sell daily in aggregate 500,000 shares not based on inside information and 200,000 shares based on inside information. The officers responsible for the 500,000 innocent sales on any given day are not likely on average to start saving again immediately in amounts that are large in relation to their recent sale of securities for consumption. Therefore, we will assume that, in the aggregate, such officers will within six months only acquire $10 \%$ of the amount they sold of their respective issuers' shares, or 50,000 shares. Ac- 
cording to the analysis above, ${ }^{82}$ each of the officers responsible for the 200,000 shares sold on the basis of inside information will want, as soon as that information becomes public, to repurchase the same number of shares as he sold. Again, we will assume that all such information will become public within six months.

We can extrapolate these figures to a steady state to evaluate our rule of inference. On a given day, 700,000 shares would be sold by officers. Of these sales, 250,000 would be matched by repurchases within the next six months - 200,000 repurchases by officers who sold on the basis of insider information, and 50,000 by officers who did not. A rule of inference that all sales followed by purchases within six months were made on the basis of inside information would have a $10 \%(50,000 / 500,000)$ Type I error (finding an innocent sale guilty) and a $0 \%$ Type II error (finding a guilty sale innocent).

c. Conclusion. The foregoing suggests that in a world with only negative inside information, the first rule of inference - which focuses on sales preceded by purchases within six months - is useless, and that the second rule of inference - which focuses on sales followed by matching purchases within six months - has real probative value. This result parallels the analysis in the discussion of a world with only positive inside information of the rule of inference that focuses on purchases followed by sales within six months. The rules of inference that turn out to be probative in both worlds focus on whether or not the first transaction is based on inside information. The fact that the first transaction is followed within six months by the second substantially increases the likelihood that the first transaction was based on inside information. The fact that the second transaction is preceded within six months by the first does not add at all to the likelihood that the second transaction was based on inside information. As Part III will indicate, this is an important point that is often missed in both judicial and SEC decisions interpreting the reach of section $16(b)$.

\section{Purchase and Sale Behavior If Section 16(b) Is Applied}

If section 16(b) applies and is enforced, what will happen to purchase and sale behavior in this section's scenario, in which all inside information is negative so that only sales, not purchases, can be based on inside information?

82. See supra note 59 and accompanying text. 
a. The first possible rule of enforcement: penalize those sales preceded within six months by a purchase. Consider an officer who purchases shares of the issuer and then, before six months elapses, receives negative inside information. In the absence of the section 16(b) penalty, he would wish to sell some issuer shares before the information became public, or within six months. However, if the current share price exceeds the initial price, application of this first rule of enforcement will force him to give up the difference to the issuer for each share he sells up to the number he purchased in the last six months. He will be faced with the choice of selling, which means paying the penalty, which may or may not be greater than the decline in share price he expects to avoid by selling, or postponing his sale until the expiration of the six-month period, which means taking the chance that the information will have already become public. In at least some cases he will choose to postpone the sale and the information will become public before the expiration of the period so that the sale would no longer be worthwhile. In those cases, the statute prevents a sale that would otherwise occur based on inside information.

Before we can conclude that this first rule of enforcement represents wise policy, however, we need to examine the costs it imposes on the officer who wants to engage in innocent sales and, given the costs, consider whether the rule makes sensible distinctions between the pairs of transactions that section 16(b) should cover and the pairs it should not cover. Specifically, we are concerned with an officer who purchases shares of the issuer and then, before six months elapses, encounters a consumption need or other investment opportunity that causes him to wish to sell some or all of his invested savings. The first rule of enforcement would force him to choose between paying the penalty or postponing the sale of issuer shares. If he postpones the sale, he must choose either not to consume or to dediversify his portfolio by selling other securities to meet his needs. Assuming that the officer knows, at the time he decides whether or not to purchase the issuer shares, that he might face this unpleasant choice if a consumption need or opportunity arises in the next six months, there is nothing unfair about imposing the burden on him. It is just one more risk associated with this security that he needs to take into account in determining the composition of his portfolio. But imposition of this risk does impose a cost, because it will make the purchase of issuer shares less attractive. From the officer's perspective, his own corporation's shares are less liquid than alternative publicly traded shares, so he will 
want to choose a smaller percentage of those shares for his portfolio. As we saw in Part I, the resulting reduction in officer and director holdings of such shares is, ceteris paribus, unfortunate, because such holdings reduce the agency costs of management.

Do the gains the first rule of enforcement offers by deterring insider trading exceed the costs the rule imposes by reducing officer and director holdings of issuer shares? No absolute answer can be given to this question, but we can see that, in terms of such gains and losses, the requirement does not discriminate in any rational way between the pairs of transactions it covers and the ones it does not. This follows from our discussion above of the rules of inference, in which we concluded that the fact that a sale was preceded by a purchase in the prior six months says nothing about the likelihood that the sale was based on inside information relative to a sale not preceded by so recent a purchase. To see the lack of rational discrimination between pairs of transactions, consider what would happen if that rule of enforcement were extended to cover a group of sales it does not now cover: those sales preceded by a purchase in the period between six months and a year prior to the date of sale. The total number of potential sales covered by the rule would increase and the number of guilty sales deterred would increase proportionally. But the rule's costs - the burden it would impose on an officer wishing to sell for some other reason - would also increase proportionally. There is no more reason to impose the rule on the portion of all sales preceded by purchases within six months than on any other portion of sales. Ultimately, in a world in which there is only negative inside information, if we are unwilling to impose the rule on every sale by an insider preceded by a purchase however far back, we should not impose it on the portion of such sales preceded by purchases within six months.

$b$. The second possible rule: penalize those sales followed within six months by a purchase. Consider an officer who purchased issuer shares more than six months ago and now receives some negative inside information. As we have seen above,,$^{83}$ such information will cause him to recalculate his optimal portfolio and, in the absence of section 16(b), he would want to sell a given number of issuer shares. As soon as the information becomes public he would want to return to his initial portfolio, and as a result he would purchase back the same number of shares as he sold. The maneuvers necessary to avoid the direct effect of the second rule - postponing for six

83. See supra section II.A.1.a.iii. 
months the repurchase of the shares that he sold - make selling issuer shares less attractive and consequently will reduce the number he will sell. The second rule will thus prevent sales based on inside information to the extent of this reduction.

The second requirement would also impose a cost on the officer who wishes to sell issuer shares not based on inside information if he foresees any possibility that within the next six months he would want to begin saving again, to increase his investments in risky securities, and perhaps to repurchase issuer shares. But, absent the statute, within six months officers of public companies in our example would want in the aggregate to repurchase only a portion of the shares sold innocently on any given day - in our example $10 \%-$ whereas they would wish to repurchase $100 \%$ of the shares sold on basis of insider information. It is consequently on average more likely, in our example ten times more likely, that a potential share sale based on inside information would be burdened by the costs of evading section 16(b) than a potential share sale not based on inside information. The prospect of this burden on selling issuer shares will reduce officer ownership - a cost. But this cost will be relatively concentrated on the sales that we have assumed we want to deter - that is, sales based on inside information - so that a substantial portion of that reduction will simply be from a lessening of the prospects of making profits from insider trading.

\section{A World With Both Positive and Negative Inside Information}

What do the models for a world in which there is only positive inside information and for a world where there is only negative inside information tell us about a world that has both? The discussion below shows that there are situations in which these models have direct applicability to a world with both kinds of inside information and, when they do not, that they can be combined in a useful fashion.

\section{Direct Applicability of the Preceding Models}

Even in a world in which there is both positive and negative inside information, there are some pairs of transactions within six months of each other in which the officer involved would only have access to inside information at the time of one of the transactions. If the transaction made with access to inside information is a sale, then only the sale could be motivated by that information and, if it is, the information must be negative. The model for a world with only negative inside information is directly applicable to this class 
of paired transactions. The preceding discussion of this world suggests that only the second rule of enforcement for the statute should be applied - that is, liability if the sale is followed by a purchase within six months. The first rule of enforcement - liability if the sale was preceded by a purchase within six months should not apply. To impose the first rule would be to add pairs of transactions that cannot be logically distinguished from those left out in terms of the trade-off between deterrence of insider trading and the burden imposed on potential transactions that would not be so based. Similarly, if the transaction made with access to inside information is a purchase, only the first rule should be imposed that is, liability if the purchase is followed by a sale within six months - and not the second. Generalizing, in cases in which there is access to inside information only at the time of one of the two transactions, the statute should only require the officer to give up his profits if his access was at the time of the first transaction and not if it was at the time of the second.

\section{Combining the Models}

There are many pairs of transactions within six months of each other in which the officer has access to inside information at the time of both transactions. For these cases, the examination below suggests that it is appropriate to apply both the first and second requirements of the statute. A rule of inference concluding that in the absence of the statute any purchase and sale or sale and purchase consummated within a period of six months contains at least one transaction based on inside information would have a Type II error of zero. This is because we would expect that all purchases based on inside information would be followed within six months by a sale and that all sales based on inside information would be followed within six months by a purchase. This rule of inference would have two sources of Type I error. One would come from coupling a sale for consumption purposes with a purchase within six months that was not based on inside information. The other would come from matching a purchase for the investment of new savings with a sale within six months that was not based on inside information.

If we combined the examples used to illustrate the two preceding models, we would have some idea of the magnitudes of these transactions and of the Type I error. Again assume a steady state in which there are 500,000 purchases daily of issuer shares by officers of public corporations based on inside information, 500,000 original 
purchases not so based, and 200,000 repurchases representing readjustments to the original portfolios of officers who had sold on the basis of inside information in the prior six months. If we look at the sales on any given day, there will be 500,000 sales of shares that were previously purchased on the basis of inside information. All of these shares will have been purchased within the prior six months and the sales will represent readjustment back to the officers' original portfolios. The other 700,000 sales will be of shares that were not purchased on the basis of inside information. Of these 700,000 sales, 200,000 will have been motivated by inside information and 500,000 will not. Of the 500,000 sales not motivated by inside information, 100,000 will have as their origins purchases made within the last six months and will be a source of Type I error. ${ }^{84}$

The second source of Type I error will come from the officers making the 500,000 innocent sales. Some portion of these officers will within six months undertake purchases not based on inside information of 50,000 issuer shares, the second source of Type I error.

Total Type I error cannot be calculated yet because we do not know the denominator for this second source; we do not know how many of the 500,000 daily purchases that are not based on inside information were made by officers who at some point in the past had held issuer shares, sold them to consume, and now intend to save again. The least it can be is 50,000 - which assumes that any such purchases that do occur, occur within six months of the sale and the most it can be is 500,000 - which assumes that all purchases not based on inside information are purchases by officers who sold at least as many shares at some point in the past. Thus the range of the Type I error is from $(100,000+50,000) /(500,000+$ $50,000)$, which equals $27 \%$, to $(100,000+50,000) /(500,000+$ 500,000 ), which equals $15 \%$. Alternatively, if we think about the problem from a Bayesian perspective, adding the fact that a purchase was followed or preceded within six months by a sale to the fact that the purchase was by an insider increases the probability that it was based on inside information from $42 \%$ to $59 \% .{ }^{85}$ Similarly, adding the fact that a sale was followed or pre-

84. See supra section II.B.2.a.

85. The probability that a purchase is based on inside information conditional on the purchaser being an officer of the issuer is $500,000 /(500,000+500,000+200,000)$, or $42 \%$, because we know that there will be $1,200,000$ purchases by officers per day, of which 500,000 will be motivated by inside information (the others being 500,000 purchases not based on inside information and 200,000 repurchases representing readjustments back to the original portfolio after an earlier sale motivated by inside information). The probability that a 
ceded within six months by a purchase to the fact that the sale was by an insider increases the probability that it was based on inside information from $17 \%$ to $24 \% .{ }^{86}$

This discussion of the application of the rule of inference suggests that when both rules of enforcement for the statute are imposed on paired transactions with six months of each other, transactions that are based on inside information are always burdened whereas only a portion of innocent transactions are burdened - in our example between one-in-four and one-in-seven.

\section{Determining the Reach of the Statute}

The model developed in Part II demonstrates that a legal regime employing the general approach of section $16(\mathrm{~b})$ will deter insider trading. It also sets up a theoretical framework that will be useful in determining the appropriate reach of the statute. This Part will address directly which pairs of transactions section 16(b) should cover. It begins by proposing an overall principle of statutory reach derived from the statute's internal logic, other evidence of congressional intent, and a concern for economic efficiency. It then considers more specifically, through the use of hypothetical examples, different kinds of paired transactions. In the process, this Part confronts many of the major issues faced by the courts and the SEC in applying section 16(b).

purchase is based on inside information conditional on the purchaser being an officer and the purchase being followed or preceded by a sale within six months is $500,000 /(500,000+$ $100,000+50,000+200,000)$, or $59 \%$, because we know that among all purchases of issuer shares by officers on a given date, 850,000 will be followed by or preceded by a sale within six months and 500,000 of those will be based on inside information. The others will be the 100,000 purchased not on the basis of inside information and sold within six months, the 50,000 shares purchased by officers who had sold not on the basis of inside information within the last six months, and the 200,000 readjusting repurchases.

86. The probability that a sale is based on inside information conditional on the purchaser being an officer of the issuer is $200,000 /(500,000+500,000+200,000)$, or $17 \%$, because we know that there will be $1,200,000$ sales by officers per day of which 200,000 will be motivated by inside information. The others will be 500,000 sales not based on inside information and 500,000 sales representing readjustments back to the original portfolio after earlier purchases based on inside information. The probability that a sale is based on inside information conditional on the seller being an officer and the sale being followed or preceded by a sale within six months is $200,000 /(200,000+100,000+50,000+500,000)$, or $24 \%$, because we know that among all sales of issuer shares by officers on a given date, 850,000 will be followed by or preceded by a sale within six months and 200,000 of those will be based on inside information. The others will be the 100,000 sold not on the basis of inside information that had been purchased not on the basis of inside information within the last six months, the 50,000 shares purchased within the next six months by officers who had sold not on the basis of inside information, and the 200,000 readjusting sales. 


\section{A. An Overall Principle of Decision}

The fundamental purpose of section $16(\mathrm{~b})$ is to deter insiders from profiting at the expense of outsiders through the insiders' access to nonpublic information and to do so without requiring evidence that such nonpublic information was actually used. This purpose is apparent from the statute's language and legislative history, and it has been repeatedly affirmed by the courts. ${ }^{87}$ As noted in Part I, the simplest and most effective way of accomplishing this

87. The preamble to $\S 16(b)$ states explicitly that the section was enacted "[f]or the purpose of preventing the unfair use of information which may have been obtained by such [statutory insider]." Exchange Act § 16(b), 15 U.S.C. \& 78p(b) (1988). The statute's purpose is reflected as well in the congressional testimony of Thomas Corcoran, one of the three principal drafters of the 1934 Act:

Next comes the everlasting problem of protecting the fellow on the outside from the insider .... That is, the problem of protecting the stockholder - and every fellow who buys into the market is a stockholder - who does not know as much about the company as the fellow on the inside.... [T] he poor little fellow does not know what he is getting into, and it is just as important as preventing unwarranted and destructive speculation, to have the fellow on the outside protected from the fellow on the inside who is an officer or director of the corporation or a pool with inside information, as it is not to let the little fellow buy too much stock by setting the margins too low.

Stock Exchange Regulation: Hearing on H.R. 7852 and H.R. 8720 Before the House Comm. on Interstate and Foreign Commerce, 73d Cong., 2d Sess. (1934) [hereinafter House Hearings] (statement of Thomas G. Corcoran, Counsel, Reconstruction Fin. Corp.), reprinted in 8 LEGislative History of the Securities Act of 1933 and Securities Exchange Act of 1934 item 23, at 85 (J.S. Ellenberger \& Ellen P. Mahar eds., 1973) [hereinafter LegisLATive HISTORY].

This interpretation of the statute's substantive purpose was affirmed by the Second Circuit in Smolowe v. Delendo Corp., 136 F.2d 231, 235 (2d Cir.) (citing congressional hearings that "indicate that $\S 16(\mathrm{~b})$, specifically, was designed to protect the 'outside' stockholders against at least short-swing speculation by insiders with advance information"), cert. denied, 320 U.S. 751 (1943). Smolowe's reasoning has been affirmed in several subsequent opinions of the Supreme Court. See, e.g., Foremost-McKesson, Inc. v. Provident Sec. Co., 423 U.S. 232, 243 (1976); Kern County Land Co. v. Occidental Petroleum Corp., 411 U.S. 582, 591-92 (1973); see also Reliance Elec. Co. v. Emerson Elec. Co., 404 U.S. 418, 428 \& n.2 (1972) (Douglas, J., dissenting).

Two legal scholars, Steve Thel and Karl Okamoto, each recently have argued that despite the language of $\S 16(\mathrm{~b})$ 's preamble, deterrence of trading on nonpublic information is not its primary substantive purpose. Professor Thel proposes that the primary purpose of $\S 16$ is to discourage insiders "from manipulating corporate affairs to create corporate opportunities to trade corporate stock profitably." Thel, supra note 5, at 399. Presumably, at least as far as subsection (b) is concerned, the main manipulation that Thel is alluding to is the affirmative issuance of false or misleading information, rather than business decisions that create share price volatility or are otherwise suboptimal. I make this presumption because in an efficient market in which insiders refrain from trading on nonpublic information, business decisions that make earnings more volatile would not create opportunities for insiders to profit on the short-swing. This is because when the insider has no nonpublic information, she is in no better position than the outsider to know which way the price will swing, even if she knows that sharp swings are likely to occur frequently. Similarly, suboptimal business decisions will be reflected in market price before the insiders trade and thus present no profitable trading opportunities, either short or long term. Section 16(b) can help deter false or misleading information because the truth usually will come out within six months.

On the other hand, Professor Okamoto contends that the primary purpose of $\S 16(\mathrm{~b})$ is to deter insiders from trading to affect market prices artificially - that is, by buying and thus sending a price-increasing positive signal to the market when there is in fact no undisclosed positive information about the issuer and then selling at a profit before the price drops to its 
purpose would be to penalize all transactions by officers and directors in their own firm's equity securities because all such transactions are potentially motivated by inside information. Congress did not choose this route. Instead, it imposed penalties only on certain classes of paired transactions by officers and directors. These classes were identified in general terms by a formula related to their nature and timing.

The decision by Congress to carve out a large portion of all transactions by officers and directors and not to subject them to the penalties of the statute reflects a concern that a broader reach would be too damaging to managerial share ownership and its attendant benefits. ${ }^{88}$ Congress would not have decided upon such a complex formula for identifying the classes of transactions that are and are not to be penalized unless it expected that the penalized classes would contain a larger proportion of transactions motivated by inside information than would the classes not penalized. The

original level after the market realizes that the positive signal has not been subsequently confirmed by the announcement of positive news. Okamoto, supra note 5, at 185 .

A significant element in the arguments of both these scholars is that we should ignore $\S 16(\mathrm{~b})$ 's preamble because $\S 16(\mathrm{~b})$ 's design is manifestly ineffective at deterring trading on nonpublic information. Id. at 184-85; Thel, supra note 5, at 397-98. Congress, therefore, could not really have intended the statute to do that and it must have had some other purpose. The model in Part II undermines this argument by showing that $\S 16(\mathrm{~b})$ is not as ineffective at achieving its stated purpose as Thel and Okamoto believe. In any event, as subsequent discussion will show, neither false or misleading statements made by insiders to create trading opportunities nor trades by insiders to reap profits from false signals that the trades create call for including within the reach of $\S 16(\mathrm{~b})$ any class of insider transactions that the principle of decision recommended here does not include.

Congress intended that the substantive purpose of $\S 16(\mathrm{~b})$ be achieved by a relatively mechanical procedure. This procedural goal is again reflected in the congressional testimony of Thomas Corcoran. See Stock Exchange Practices: Hearings on S. Res. 84 (72d Cong.) and S. Res. 36 and S. Res. 57 (73d Cong.) Before the Senate Committee on Banking and Currency, 73d Cong., 1st Sess., pt. 15 (1934) [hereinafter Senate Hearings], reprinted in 6 LegisLATIVE History, supra, item 22, at 6557 . This goal was also recognized by the Second Circuit in Smolowe, in which the court found that there was no need to prove the actual use of inside information in order to prevail under $\S 16(\mathrm{~b})$. $136 \mathrm{~F} .2 \mathrm{~d}$ at 236.

88. See, e.g., Reliance Electric, 404 U.S. at 422 ("Congress did not reach every transaction in which an investor actually relies on inside information."); 404 U.S. at 431 n.7 (Douglas, J., dissenting) (noting that $\S 16$ (b) "represents a balance struck between the need to deter shortswings based on inside information and a desire to avoid unduly inhibiting long-term corporate investment"). The same concern is articulated in Blau v. Max Factor \& Co., 342 F.2d 304 (9th Cir.), cert denied, 382 U.S. 892 (1965). According to Max Factor, Congress recognized that

the affirmative value of long-term personal financial commitments by insiders to the prosperity of the companies which they controlled was obviously great. Thus, by basing forfeiture of profits upon the length of the insider's investment commitment, Congress sought to minimize misuse of confidential information, without unduly discouraging bona fide long-term investment.

342 F.2d at 308. Steve Thel's extensive review of the legislative history of $\S 16$ supports the conclusion that one of Congress's central concerns was the separation of ownership and control in the modern public corporation and the need to provide incentives to align the interests of management and shareholders. Thel, supra note 5, at 452-89. 
model in Part II suggests that Congress was realistic in its expectation: assuming that six months is an appropriate time frame, a scheme working along the lines of section 16(b) can discriminate in this fashion.

The foregoing discussion of congressional intent suggests an overall principle of decision for the courts and the SEC in applying section 16(b) to pairs of transactions not unambiguously within the words of the statute. A given class of paired transactions should be included within the coverage of section $16(b)$ only if, like the ordinary cash-for-security transactions that are clearly within the statute's reach, the potential officer-and-director transactions belonging to the class contain a significantly larger proportion of transactions motivated by inside information than do potential officer-and-director transactions generally. Not only does this principle of decision separate out the paired transactions Congress would have wished to reach, but it also has the attraction of enhancing economic efficiency, a value whose importance has been increasingly emphasized in scholarly work and judicial opinions relating to corporate and securities law in the sixty years since the passage of the Securities Exchange Act. ${ }^{89}$ The non-insider-trading rewards of managerial share ownership and share-price-based compensation can, as outlined in Part I, significantly reduce the agency costs associated with large, publicly held corporations. For any given level of deterrence of insider trading, the proposed principle puts less of a burden on these mechanisms of agency cost reduction than a principle that would include within section 16(b)'s coverage any additional classes of potential transactions. As the hypotheticals below will show, the model developed in Part II and the just-proposed principle of decision provide a reliable guide for determining the reach of the statute.

\section{B. Must the Term in Office Include the Time of Purchase or Sale?}

\section{The Time of Purchase}

Consider the following hypothetical: $X$, who at the time has no relationship with $\mathrm{ABC}$ Corporation, buys $100 \mathrm{ABC}$ shares at $\$ 50$ on January 1. $X$ becomes an officer of ABC on March 1. While still an

89. See, e.g., Basic Inc. v. Levinson, 485 U.S. 224, 246-47 (1988) (utilizing the efficient market hypothesis as the basis for making a presumption of reliance in thickly traded securities markets); Frank H. EAsterbrook \& Daniel R. Fischel, The Economic STructure OF CORPORATE LAW (1991) (applying economic analysis to a wide variety of corporate and securities law issues). 
officer, $X$ sells his 100 shares at $\$ 60$ on May 1 . Should $X$ 's $\$ 1,000$ profit be recoverable by $\mathrm{ABC}$ under section 16(b)?

a. Application of the principle of decision. The purchase in the hypothetical could not have been based on information obtained by reason of $X$ 's relationship with $\mathrm{ABC}$, because $X$ was not an officer at the time. The sale, however, could be based on inside information. Because the only kind of inside information that motivates sales is negative information, we can analyze the question with the model for a world in which there is only negative inside information.

The class of paired transactions at issue here are purchases followed within six months by sales by individuals who are officers only at the time of sale. Inclusion of this class under section 16(b)'s coverage would deter some sales based on inside information, because it would create an incentive for officers receiving negative information less than six months after purchasing a security to postpone their sales for six months, by which time the information would presumably have become public. But inclusion of this class of transactions also burdens potential sales that are not based on inside information. As the discussion of the model demonstrates, ${ }^{90}$ the fact that a sale is preceded by a purchase within six months rather than some longer period adds nothing to the probability that the sale is based on inside information. The deterrence or nondeterrence of potential sales as a result of the six-month cutoff is in no way related to whether or not the sales are based on inside information.

The proposed principle of decision therefore suggests that $A B C$ should not be able to recover $X$ 's profits. No larger portion of potential officer-and-director sales in the class are motivated by inside information than officer-and-director sales generally. By parallel reasoning, it can be established that section 16(b) should not reach sales followed within six months by purchases when the officer is an insider only at the time of the purchase. Thus the above hypothetical is in fact a member of a larger class of paired transactions that, according to the overall rule of decision, should not be included within the reach of section 16(b) - those transactions in which the officer or director does not have that status at the time of the first transaction but does at the time of the second.

90. See supra section II.B.2.a. 
b. Court decisions. The Second Circuit, in Adler v. Klawans, ${ }^{91}$ confronted a case identical in its relevant details to the hypothetical and held that section 16(b) was applicable even though the director involved had that status only at the time of the sale and not earlier at the time of the purchase. ${ }^{92}$ At least until the wholesale SEC revision of the section 16 rules in $1991,{ }^{93}$ the Adler holding was generally considered authoritative, ${ }^{94}$ so $X$ 's profits would be recoverable by $\mathrm{ABC}$, an outcome contrary to the recommendation supported by the proposed overall principle of decision.

The reasoning in the Adler decision demonstrates how courts have approached questions concerning the scope of section 16(b) and illustrates the problems they encounter because of the lack of an overall theory of the statute. The specific issue raised in the hypothetical and the case is not by itself of large importance to the proper functioning of the economy. It provides, however, a relatively simple context in which to explore some larger issues that are highly relevant to the correct treatment under section $16(\mathrm{~b})$ of various forms of share-price-based management compensation, which in turn is of large importance to the economy.

The Adler court first acknowledged that applying the conventional rules of construction to the operative language of 16(b) did not resolve the issue before it; the defendant director could argue that the statute should not be interpreted as reaching his paired

91. 267 F.2d 840 (2d Cir. 1959).

92. 267 F.2d at 847 .

93. See infra section III.C.2.c.

94. Adler was expressly followed in Marquette Cement Manufacturing Co. v. Andreas, 239 F. Supp. 962, 966 (S.D.N.Y. 1965). The Supreme Court has also cited Adler approvingly. Reliance Elec. Co. v. Emerson Elec. Co., 404 U.S. 418, 424 n.4 (1972). See also Arrow Distrib. Corp. v. Baumgartner, 783 F.2d 1274, 1279 (5th Cir. 1986) ("[A]n insider's short-swing transaction is subject to $\S 16(\mathrm{~b})$ if the insider has held his corporate position at either the time of his purchase or the time of his sale."); Steinberg \& Landsdale, supra note 12, at 70-72 (noting that all the major courts that have directly addressed the issue have held that an officer or director need only hold the position at the time of either purchase or sale to be liable under $\S 16(b))$.

The ALI's proposed ALI Federal Securities Code would codify the Adler holding by providing that liability arises for the short-swing profits of a director or officer "if the defendant has that status at the time of either the purchase or the sale or at any time between the two transactions." ALI Federal Securities Code § 1714(c) (1978).

Support for the Adler position is not unanimous, however. Since Reliance Electric, the Supreme Court has withheld judgment on the authoritativeness of Adler. ForemostMcKesson, Inc. v. Provident Sec. Co., 423 U.S. 232, 243 n.16 (1976) ("Since we rely on the exemptive provision, we intimate no view on the proper analysis of a case where a director or officer makes an initial transaction before obtaining insider status."). In Allis-Chalmers Manufacturing Co. v. Gulf \& Western Industries, Inc., 527 F.2d 335, 347-48 \& n.13 (7th Cir. 1975), cert. denied, 423 U.S. 1078, 424 U.S. 928 (1976), the court rejected the reasoning of Adler, saying that "to be charged with a section 16(b) violation, [an insider] must only have had insider status prior to the initial purchase or sale." 527 F.2d at 348. 
transactions. ${ }^{95}$ The court concluded, however, that the statute was remedial, not penal, and hence should be interpreted in the fashion most consistent with the legislative purpose. ${ }^{96}$ The court suggested that intent and purpose must be "glean[ed] from the statute as a whole" and not from its "isolated parts." 97 The court then found, based on the language of the statute as a whole, that the objective was to deter insiders from making improper use of information gathered in a representative capacity by taking the profit out of such conduct. ${ }^{98}$

The court's description of how it should go about applying the statute when its language is ambiguous thus closely resembles the approach we used to derive the proposed overall principle of decision. The court's reasoning and our analysis differ, however, concerning the significance of the six-month limitation. The proposed principle of decision rests upon a discerned logic behind this sixmonth limitation. The Adler court did not rest its analysis on any such logic:

Large areas of "insider" conduct were consciously left untouched by Congress for reasons dictated by practicalities rather than ethics or pure logic. A line had to be drawn somewhere by the lawmakers, as they do in the laws of ... a host of other subjects governed by statute.

95. 267 F.2d at 844 . The court suggested that all that is plain from the first sentence of $\S 16(\mathrm{~b})$ is that Congress intended to reach purchases and sales within a period of six months by "one who was a director, officer or beneficial owner at some time." 267 F.2d at 844. But conventional rules of construction alone cannot resolve the question "At what time?" In fact, the court said, "If Congress had made such profits the subject of a criminal penalty ... appellant's [the director] argument would carry much weight for we would be obliged to construe it strictly." 267 F.2d at 844.

96. 267 F.2d at 844 . See infra note 100 for a discussion suggesting that categorizing the statute here as "remedial" is not useful as an aid in its construction. There is, in any event, a certain irony in the court's apparent belief that it had to characterize the statute as remedial in order to invoke principles of construction that assisted the court in coming to its conclusion. The measure of damages if $\S 16(\mathrm{~b})$ were applied to the class of paired transactions at issue would be the sale price minus the purchase price - in the hypothetical, $(\$ 60-\$ 50) \times$ $100=\$ 1000$. If the concern were that the purchase was motivated by inside information, this could reasonably be characterized as a remedial payment to the corporation. The true value of the security as measured by a fully informed market would be $\$ 60, \$ 50$ would represent the bargain price at which the officer purchased the shares because the market was not aware of the information possessed by the officer, and $\$ 10$ would represent the gain to the insider at the expense of the outsiders. Here, however, the concern is that the sale is motivated by inside information, that is, by knowledge of information that will push the price down when it becomes public. The advantage the officer gains if he possesses inside information is the avoidance of a loss. The fact that $X$ purchased the shares at $\$ 10$ less than he sold them for is completely unrelated to the size of that advantage. To make a comparable rough measure of $X$ 's advantage, the sale price would have to be compared with the market price at some point after, not before, the sale.

97. 267 F.2d at 844.

98. 267 F.2d at 844 . 
But the consciously limited scope of the statute is no reason for us to seek yet further limitations of what is remedial legislation. ${ }^{99}$

The Adler court concluded its analysis of the issue by citing other cases in which the Second Circuit resolved ambiguities in the language of the statute. Though these cases address different issues arising under section 16(b), the Adler court argued that they demonstrate that "the purpose of the statute is remedial, rather than penal, and that it must be strictly construed in favor of the corporation and against any person who makes [a] profit dealing in the corporation stock."100 The court's logic, in essence, is that because section 16 (b) is designed to deter trading on inside information, it should be applied to every class of paired transactions potentially so motivated that the statute's language could possibly reach. ${ }^{101}$

99. 267 F.2d at 845 .

100. 267 F.2d at 846-47. Thus, at this point the court uses its characterization of the statute as "remedial" to justify construing it, not just in accordance with its purpose, but "liberally" against insider defendants. This appears to reflect the traditional, but increasingly discredited, canon of statutory construction that "a remedial statute should be liberally construed in order to effectuate the remedial purpose for which it was enacted." 3 NORMAN J. Singer, Statutes and Statutory Construction $\$ 60.01$, at 147 (5th ed. 1992). The canon does not seem to have much meaning beyond being the inverse of the proposition that because of special due process concerns, a defendant accused of violating a criminal statute should not be convicted unless there is clear notice that her behavior was illegal. The standard treatise in the area has noted that "[w]hen 'remedial' is used to mean all laws other than those which are penal, the scope of its reference is broad and indiscriminate. For this reason, it is not unusual for a court to give what it calls a strict construction to a statute which it nevertheless describes as remedial." 3 id. $\$ 60.01$, at 148 . Moreover, it is often difficult to distinguish between remedial and penal statutes, as a single statutory provision "may be either penal or remedial according to the way in which different parties are affected by it." 3 id. $\S 60.03$, at 160 . Other commentators have also found the canon to be useless. See, e.g., Richard A. Posner, Legislation and Its Interpretation: A Primer, 68 NeB. L. Rev. 431, 442 (1989); Cass R. Sunstein, Interpreting Statutes in the Regulatory State, 103 HARv. L. REv. 405, 459 n.201 (1989). The more sensible route to interpreting a statute is to forgo characterizing it as remedial or penal and to construe it to give effect to the statutory purpose, an approach that has become increasingly orthodox. See 3 Singer, supra, § 60.01, at 148, § 60.04, at 16364 ("[T]he court should determine what the legislative intent [is] and follow it.").

101. The court in Adler suggested one other independent argument for its holding. The last sentence of the statute provides that $\S 16(\mathrm{~b})$ "shall not be construed to cover any transaction where such beneficial owner [the beneficial owner of more than $10 \%$ of any class of equity security] was not such both at the time of the purchase and sale, or the sale and purchase, of the security involved." Exchange Act § 16(b), 78 U.S.C. § 78p(a) (1988). The court argued that because this "exemptive provision" refers only to insiders who acquire that status by reason of being a $10 \%$ holder, the provision evidences, by application of the canon of construction expressio unius est exclusio alterius, a clear legislative intent to treat directors and officers differently. 267 F.2d at 845 .

It is not at all obvious that the exemptive provision shows such an intent. The clause's function may simply be to make clear that the time for determining whether a beneficial shareholder is a greater than $10 \%$ holder is the moment immediately prior to entering into a short-swing transaction and that the effect of the first transaction in the pair on the percentage of shares held should not be counted. Although the presence of the word "both" initially makes this construction appear strained, an examination of the sequence of the draft bills that culminated in $\S 16(\mathrm{~b})$ and the surrounding legislative history shows otherwise. See infra 
The flaw in the court's reasoning ${ }^{102}$ is its failure to attach any significance to Congress's decision to impose the six-month limitation. By blandly asserting that a line must be drawn somewhere and refusing to explore the "practicalities" that caused Congress to include the limitation, the court missed the fact that Congress was evidently trying to balance two concerns: deterring insider trading and preserving managerial share ownership. ${ }^{103}$ Decisions as to the reach of the statute should take into account both concerns. The

note 104. This explanation for the presence of the exemptive provision was adopted in AllisChalmers by the Seventh Circuit, which concluded that an insider, to come within the reach of $\S 16(b)$, must have that status prior to the initial purchase or sale. Allis-Chalmers Mfg. Co. v. Gulf \& W. Indus., Inc., 527 F.2d 335, 345 (7th Cir. 1975), cert. denied, 423 U.S. 1078, 424 U.S. 928 (1976).

Even if this explanation of the exemptive provision is incorrect and the provision in fact does show an intent to treat officers and directors differently from $10 \%$ shareholders, its existence is still not a persuasive argument that $\S 16(\mathrm{~b})$ should cover the transactions in question. Officers and directors would be treated differently than $10 \%$ holders if the rule, in the case of a purchase followed by a sale, required insider status at the time of the purchase but not at the time of the sale. Exactly such a rule for directors and officers is proposed later in this article. See infra section III.B.2. Under such a rule, the defendant director in the Adler case and $X$ in our hypothetical would not need to return their profits. A possible rationale for Congress's requiring that $10 \%$ shareholders have that status at the time of the sale as well as the time of the purchase would be that long-term large shareholders have more access to inside information than short-term ones.

102. It is possible to interpret what has been criticized here as the court's "reasoning" really to be a formalistic recitation that is regularly invoked when the court for other reasons decides against the defendant. If this interpretation of the opinion is adopted, the likely "real" reason for the decision is the fact that the defendant director sold a large number of shares within ten days after becoming a director. 267 F.2d at 843 . This fact leads to the inference that the sales were based on negative inside information that the director learned at his first directors' meeting. In addition, he moved a resolution that the corporation purchase in the market some of its own stock, thereby supporting the price, at a time that would coincide with his own undisclosed sales, 267 F.2d at 845-46, an action that strengthens the inference of insider trading because it suggests that the director took his fiduciary responsibilities lightly.

This interpretation does not make the court's decision any more defensible. To start, in the opening paragraph of the opinion the court framed the issue as whether $\S 16(\mathrm{~b})$ covers profits "made on sales of the corporation's stock by the director of a corporation while holding such office but who was not a director when he purchased the stock less than six months earlier." 267 F.2d at 842 . The court held that $\S 16$ (b) does cover such profits. 267 F.2d at 847. Given how baldly the court stated its holding, the relatively mechanistic structure of $\S 16$ (b), the normal deference that district courts give court of appeals holdings, and the preeminent position of the Second Circuit in the interpretation and application of $\S 16(b)$, this holding is likely to be regarded by insiders as having significant predictive value for cases falling into the category described by the holding. This is true regardless of whether they include the other "facts" that may have led the court in this case to suspect insider trading. Thus, the court should have addressed, as it purported to do, the issues raised by the apparent rule laid down by its holding.

It could be argued that any case falling within the class of paired transactions covered by the rule will involve a sale within six months of the insider's becoming a director or officer, supporting some inference, though perhaps not as strong as the one raised by the actual facts of the Adler case, that the sale was motivated by what he found out when he became a director. But this more general inference is not a sound basis for the decision because it is unrelated to whether the purchase was made less than six months before the sale, the crucial factor for determining the applicability of $\S 16(b)$.

103. See supra notes $87-88$ and accompanying text. 


\section{models in Part II show that if we take account of both concerns, section 16(b) should not apply to paired transactions when the of- ficer or director does not have that status at the time of the first trade. ${ }^{104}$}

104. The logic of the overall structure of the statute - limiting profit recovery only to short swings - is not the only evidence that this rule is consistent with the intent of Congress. As detailed below legislative history and the statutory measure of damages both provide strong additional support that Congress contemplated that the officer or director would have that status at the time of the first transaction. Also, many, but not all, commentators who have considered the question also agree that Congress was focusing on the possibility of abuse only at the time of the first transaction.

As first introduced in both the Senate and the House, the draft of the part of the Exchange Act bill that was to become $\S 16(\mathrm{~b})$ read:

(b) It shall be unlawful for any [statutory insider]

(1) To purchase any such registered security with the intention o[r] expectation of selling the same security within six months; and any profit made by such person on any transaction in such a registered security extending over a period of less than six months shall inure to and be recoverable by the issuer, irrespective of any intention or expectation on his part in entering into such transaction of holding the security purchased for a period exceeding six months.

S. 2693, 73d Cong., 2d Sess. $\S 15$ (b) (1934) (emphasis added), reprinted in Senate Hearings, supra note 87, reprinted in 6 LEgISLATIVE HISTORY, supra note 87, item 22, at 6422, 6430; H.R. 7852, 73d Cong., 2d Sess., § 15(b) (1934), reprinted in Housing Hearings, supra note 87, reprinted in 8 LegisLATIVE HISTORY, supra note 87 , item 23 , at $1,1$.

The final version of the bill involved two changes of importance here. The first part, prohibiting a purchase with a short-swing intention or expectation of sale, was dropped, apparently because it would be so difficult to enforce. Thel, supra note 5 , at 472 . The second part, providing for the recovery of profits irrespective of intention or expectation, was changed so that "any transaction ... extending over a period of less than six months" became "any purchase and sale, or any sale and purchase ... within any period of less than six months." Exchange Act $\S 16(b), 15$ U.S.C. $\S 78 p(b)$ (1988). The "any purchase and sale" part of the second change was obviously necessitated by the deletion of the prohibition of a purchase with intention to sell short-swing, because a reference to a transaction extending over less than six months would not, standing alone, make any sense. The "sale and purchase" part of the second change appears to correct the original draft's oversight of the fact that an insider can use short-swing trading to make a profit and return to her original position just as easily with negative as positive information. Allis-Chalmers, 527 F.2d at 34647. The final version left essentially unchanged the last clause of the early version providing recoverability "irrespective of any intention on [the part of such insider] in entering into such transaction of holding the security purchased or not repurchasing the security sold for a period exceeding six months." Exchange Act § 16(b), 15 U.S.C. § 78p(b) (1988) (emphasis added). This strongly suggests that Congress viewed the paired purchase and sale as a unit and that the speculative behavior that concerned Congress was that which occurred at the time of the first of the two trades: Congress originally intended both to ban such behavior when intent could be proved and to require the return of profits regardless of a showing of intent when the insider reversed his position within six months, but Congress eventually settled for just the return-of-profits provision. The insider's reversal of position in essence created an irrebuttable presumption that the first trade involved the kind of speculative behavior Congress had originally wanted to ban. The testimony of Thomas Corcoran again provides confirmation:

Mr. Corcoran: [Section 16(b)(1)] is to prevent directors from receiving the benefits of short-term speculative swings on the securities of their own companies, because of inside information. ... You hold the director, irrespective of an intention or expectation to sell the security within 6 months after, because it will be absolutely impossible to prove the existence of such intention or expectation, and you have to have this crude rule of thumb, because you cannot undertake the burden of having to prove that the director intended, at the time he bought, to get out on a short swing.

Senator Gore: You infer the intent from the fact.

Mr. Corcoran: From the fact. 
c. SEC rulemaking. Prior to 1991, the SEC's section 16 rules never directly addressed the question of the applicability of section 16(b) to trades by a person who becomes an officer or director. However, in 1969, after Adler, the SEC promulgated a rule that required reporting of such prior trades under section 16(a).105 The SEC explained that it was proposing the rule in order to provide disclosure "with respect to all transactions which may be subject to section 16(b)" and cited Adler. ${ }^{106}$ In the SEC's initial 1988 release

\section{Senate Hearings, supra note 87 , at $6556-57$.}

At the time of the first transaction, a person in the position of the corporate insider in Adler could not have obtained information as a result of a statutory insider relationship to the issuer because the relationship did not yet exist. He therefore cannot engage in the particular kind of speculative behavior that Congress wished to deter.

The statute's measure of damages also supports the conclusion that the statute is aimed at speculative behavior at the time of the first transaction. As demonstrated in the example in supra note 96 , if the first trade is motivated by inside information, the difference between the purchase and sale price (the "profit realized") represents a rough but reasonable measure of the benefit gained from using the information. If it is the second trade that is motivated by inside information (the only possibility in Adler), the difference between the purchase and sale prices of the paired transactions is totally unrelated to the benefit gained from using the information.

A number of commentators agree that the concern of $\S 16(b)$ is with the misuse of inside information at the time of the first trade. See, e.g., David L. RATNER \& ThOMAs L. HAZEN, Securities Regulation: Cases and Materials 439 (4th ed. 1991); Thel, supra note 5, at 415-17. Other commentators disagree and believe that even if the only possibility of misuse of inside information is at the time of the second trade, short-swing trading is contrary to the rationale underlying § 16(b). 16 ARnold S. Jacobs, Section 16 OF the Securities ExCHANGE ACT § 3.03, at 54-55 \& n.44 (1993) (listing cases); Steinberg \& Landsdale, supra note 12 , at 75 . The commentators who disagree, however, do not attempt to justify their position in terms of the legislative history or the overall mechanics of the statute. They appear to rely simply on the facts that the second trade could be based on inside information and that the preamble says that the purpose of $\S 16(b)$ is to prevent the use of inside information.

105. See former rule 16a-1(d), 17 C.F.R. $§ 240.16 a-1$ (d) (1990) (repealed 1991), which in essence required any director or officer who engages in a trade during the first six months of service to report any trades during the six months prior to this first trade after assuming office.

106. Exchange Act Release No. 8574, 34 Fed. Reg. 7250, 7250 (Apr. 17, 1969) [hereinafter Release No. 8574] (proposing former rule 16a-1(d)). Announcement of the final adoption of the former rule in slightly modified form was in Exchange Act Release No. 8697, 34 Fed. Reg. 15,246 (Sept. 18, 1969).

It is not entirely clear what this rule implies about the SEC's own position concerning the reach of $\S 16(b)$ to pre-insider transactions. There could be significance to the fact that the SEC uses the word may in its explanation for the rule. The relationship between the transactions that must be reported under $\S 16(\mathrm{a})$ and the ones that give rise to $\S 16(\mathrm{~b})$ liability has never been fully defined. Rule 16(a)-10, 17 C.F.R. \& 240.16a-10 (1993), provides that transactions exempted by SEC rule from the operation of $\S 16(a)$ are exempt from $\S 16(b)$, but no rule has ever provided for the converse. On the contrary, the SEC has stated, "The fact that ownership of securities and transactions in those securities are reported under Section 16(a) ... does not necessarily mean that liability will arise therefrom under Section 16(b)." Exchange Act Release No. 7824, 4 Fed. Sec. L. Rep. (CCH) I 26,030, at 19,058 (Feb. 14, 1966); see also Colan v. Monumental Corp., 713 F.2d 330, 333 (7th Cir. 1983) (citing cases).

On the other hand, the SEC could have thought that a §16(a) reporting rule was all that was necessary, without seeing any reason, perhaps because of the Adler holding's simplicity and broad judicial acceptance, to make a formal rule codifying it. Because $\S 16$ (a) does not explicitly provide for SEC rulemaking, the rules under this subsection must be regarded as interpretations of statutory language. If the SEC interprets that a transaction is covered by 
concerning the possible wholesale revision of the section 16 rules, it proposed to retain its then-existing approach to pre-insider transactions. As justification for that approach, it observed, "once becoming an officer or director and gaining access to inside information, a person would have the opportunity to take advantage of that information to offset transactions made shortly before attaining insider status." 107 The SEC changed its position, however, in a subsequent release and in 1991 ultimately adopted rule 16a-2(a), which exempted from both section 16(a) and section 16(b) trades carried out before a person becomes an officer or director. ${ }^{108}$ The reason it gave for the change was the concern among commentators that inclusion of such trades under section 16(b) is "unnecessarily harsh in that it subjects [officers and directors] to liability, even though they may not have known at the time of the transactions that they would become officers or directors in the future." ${ }^{109}$

The SEC came to the right result for the wrong reason. There is nothing "harsh" about the Adler rule, once it has been established. A person who trades in a corporation's securities and within six months thereafter is given the opportunity to become its officer or director can avoid forgoing her profits from the transaction in any of three ways: she can reverse the trade before taking the job, take the job but wait the remainder of six months before reversing it, or decline the job.

Reasons matter. The SEC's power to exempt transactions from section 16(b) extends only to those transactions "not comprehended within the purpose of [the] subsection." 110 This is a real constraint, and the SEC has been found to have exceeded its power in seeking to exempt other kinds of transactions from section

$\S 16(a)$ and that interpretation is respected by the courts, then there should probably be a presumption - rebuttable with a showing that there is a reason for treating the terms differently in the two subsections - that the interpretation applies to $\S 16(\mathrm{~b})$ as well. The transaction would be within the $\S 16$ (b)'s reach unless the SEC makes a rule exempting it. Some commentators certainly seem to assume that the SEC's requiring of reporting of pre-insider transactions is evidence that the SEC interpreted $\S 16(\mathrm{~b})$ as including them within its reach as well. Steinberg \& Landsdale, supra note 12, at 70-71.

107. Initial Release, supra note 7 , at 89,602 .

108. 17 C.F.R. $\$ 240.16 a-2(a)$ (1993). Rule 16a-2(a) contains an exception to its exemption for cases in which the director or officer becomes subject to $\S 16$ of the Act solely as a result of the issuer's registering a class of equity securities pursuant to $\S 12$ of the Act. This is appropriate because in this case the insider has access to inside information at the time of the first transaction.

109. Ownership Reports and Trading by Officers, Directors and Principal Stockholders, Exchange Act Release No. 27,148 [1989 Transfer Binder] Fed. Sec. L. Rep. (CCH) 9 84,439, at 80,384 (Aug. 18, 1989) [hereinafter Reproposing Release].

110. 15 U.S.C. $\S 78 \mathrm{p}(\mathrm{b})(1988)$. 
16(b). ${ }^{111}$ The court in Adler considered whether the SEC had the power to exempt pre-insider transactions to be an open issue. The Adler court avoided this issue by concluding, contrary to the defendant's assertions, that the SEC had not sought to create such an exemption. ${ }^{112}$ Now the SEC obviously has. Professor Marc Steinberg and Daryl Landsdale, Jr., find that "the SEC has exceeded its rulemaking authority by instituting this policy." 113 Similarly, Arnold Jacobs, author of the principal treatise dedicated to section 16, concludes that "a court could easily invalidate Rule 16a-2(a)."114 Some commentators have sharply criticized this move, asserting that the underlying purpose of section $16(\mathrm{~b})$ is to deter statutory insiders from using inside information and that Adler-type matched trades present the opportunity for such abuse because of the insider's access to information at the time of the second trade - exactly the concern expressed by the SEC when initially it proposed retention of its old approach. ${ }^{115}$

The SEC needs to "take the bull by the horns" and recognize that the possibility of abuse of information at the time of the second trade is not an appropriate concern under section 16(b). Although this would be an alteration of the SEC's current position, it is, for all the reasons set out here, clearly the better reading of the statute and hence highly defensible. Given the active section 16(b) plaintiffs' bar, rule 16a-2(a) will almost certainly be challenged eventually. ${ }^{116}$ The courts are no more likely than the commentators to be

111. See, e.g., Greene v. Dietz, 247 F.2d 689, 692 (2d Cir. 1957) (in dicta, expressing doubt whether the SEC possessed the power to promulgate former rule 16b-3); Perlman v. Timberlake, 172 F. Supp. 246, 258 (S.D.N.Y. 1959) (holding that former rule $\$ 16 \mathrm{~b}-3$ was in conflict with the expressed purpose of the statute, and therefore invalid). These cases are discussed further in infra notes 248-53 and accompanying text. Similarly, in Feder v. Martin Marietta Corp., 406 F.2d 260 (2d Cir. 1969), cert. denied, 396 U.S. 1036 (1970), the Second Circuit held that rule $16 \mathrm{a}-10$, which purports to exempt from $\S 16(\mathrm{~b})$ any transaction that is exempted by the SEC from the reporting requirements of $\S 16(\mathrm{a})$, is invalid to the extent that its effect would be to exempt paired transactions in which the first trade occurs when the officer or director still holds office but the second occurs after he resigns. 406 F.2d at 268.

112. Adler v. Klawans, 267 F.2d 840, 847 (2d Cir. 1959).

113. Steinberg \& Landsdale, supra note 12 , at 78.

114. 16 JACOBS, supra note $104, \S 3.03$, at 55 .

115. See 16 id. $\$ 3.03$, at 56 (quoting Initial Release, supra note 7 , at 89,602 ); Steinberg \& Landsdale, supra note 12 , at 75 . Steinberg and Landsdale describe the rule as "giving away a crown jewel" in the SEC's war on insider trading. Id. at 69.

116. The rapidity of challenge is slowed by the doctrine, based on $\S 23(a)$ of the Exchange Act, 15 U.S.C. $\$ 78 w(a)(1988)$, that good faith reliance on SEC rules is a defense against being required to pay damages. See Colema Realty Corp. v. Bibow, 555 F. Supp. 1030, 1040 (D. Conn. 1983); Perlman v. Timberlake, 172 F. Supp. 246, 258 (S.D.N.Y. 1959); Emerson Elec. Mfg. Co. v. O'Neill, 168 F. Supp. 804, 805-06 (E.D. Mo. 1958). Thus, to challenge the rule, a member of the plaintiffs' bar will need to bring a test case that involves little likelihood of remuneration with the hope of establishing a principle that will then open up the possibility of a range of remunerative cases in the future. 
impressed with the extraordinarily weak "harshness" justification that the SEC has given for ignoring the possibility of abuse on the second trade. Unless the SEC adopts the stronger rationale advocated here, courts may well, as the commentators predict, find rule 16a-2(a) to exceed the SEC's powers. ${ }^{117}$

\section{The Time of Sale}

Consider another hypothetical. $Y$, an officer of ABC Corporation, buys $100 \mathrm{ABC}$ shares at $\$ 65$ on June 1. $Y$ resigns his position on August 1 and no longer has any relationship with ABC. $Y$ sells his 100 shares at $\$ 80$ on October 1 . Should $Y$ 's $\$ 1,500$ profit be recoverable by $\mathrm{ABC}$ ?

a. Application of the principle of decision. In this hypothetical, the sale cannot be based on inside information but the purchase can - the reverse of the preceding hypothetical. Because the only kind of inside information that motivates a purchase is positive information, we can analyze this question with the model of a world in which there is only positive information.

The class of paired transactions at issue here is purchases followed within six months by sales by those having insider status only at the time of purchase. Including this class of transactions under section 16(b)'s coverage would deter both purchases based on inside information and purchases not so based. In each case there is as at least some possibility that circumstances would arise such that the director or officer would, in the absence of the statute, want to sell issuer shares within six months. Section 16(b) would make the purchase less attractive because he knows that if these circum-

117. Rule $16 a-2(a)$ is a "legislative rule," as it is pursuant to the statutory grant of power to the SEC to make exemptions contained in Exchange Act $\S 16(\mathrm{~b}), 15$ U.S.C. $\S 78 \mathrm{p}(\mathrm{b})$ (1988). See 2 Kenneth C. Davis, Administrative Law Treatise $\S 7: 8$, at 36 (2d ed. 1979). The Supreme Court has said that "legislative regulations are given controlling weight unless they are arbitrary, capricious, or manifestly contrary to the statute." Chevron U.S.A. Inc. v. Natural Resources Defense Council, Inc., 467 U.S. 837, 844 (1984). Despite the high barrier to a plaintiff imposed by such a standard of judicial review, a plaintiff challenging the rule might well still succeed. If a court is inclined to believe that abuse of information at the time of the second trade is an appropriate concern of the statute and the SEC does not dissuade the court of that belief, a plaintiff may find it easy to persuade the court that the rule's adoption was manifestly contrary to the statute. The paired transactions exempted by the rule involve the possibility of the use of inside information, and the statute's purpose is to deter such trading whether the results are harsh or not. This argument will be particularly effective because the claim of harshness is so dubious and because the SEC has changed its position, suggesting that it previously did not interpret the purpose of the statute to include avoidance of harshness as part of the statutory purpose. See International Brotherhood of Teamsters v. Daniel, 439 U.S. 551, 566 n.20 (1979), in which the Court stated in dictum that "an administrative agency's consistent, long-standing interpretation of the statute under which it operates is entitled to considerable weight," suggesting that recently changed interpretations are entitled to less weight. 
stances do arise he will be faced with either paying the penalties of the statute for the issuer shares he has purchased or maintaining a dediversified portfolio.118 But although these circumstances are certain to arise with potential purchases based on inside information, because all inside information becomes public in less than six months, ${ }^{119}$ they are less likely to arise with innocent purchases because the pattern of savings and consumption often involves an investment period longer than six months.

The proposed principle of decision therefore suggests that $Y$ 's profits should be recoverable by ABC. The class of paired transactions in question contains a larger proportion of purchases motivated by inside information than officer-and-director purchases generally because, absent coverage by the statute, all such purchases would be sold within six months. ${ }^{120}$

Again, by parallel reasoning, the model of the world in which there is only negative inside information demonstrates that sales followed within six months by purchases when the officer has that status only at the time of sale should also be included within coverage of the statute. Thus this hypothetical is in fact a member of a larger class of paired transactions that, according to the overall rule, should be included - transactions in which the officer or director has that status at the time of the first transaction but not the second.

b. Decisions. In Feder v. Martin Marietta Corp., ${ }^{121}$ the Second Circuit confronted a case in which a de facto director purchased shares while it was still a director but resigned a month before selling them. ${ }^{122}$ The court held that section 16(b) applied. ${ }^{123}$ After citing Adler for the proposition that section 16(b) is a remedial statute that should be construed in the way most consistent with the legislature's purpose, the Feder court stated that the possibility of abuse was at least as great in the case before it as in Adler because "in the

118. See supra section II.A.3.

119. See supra section II.A.2.

120. More precisely, with potential purchases by an officer or director who subsequently resigns within six months, all such purchases based on inside information would, in the absence of applying $\S 16(\mathrm{~b})$, result in a sale within six months, whereas only a portion of those not based on inside information would result in such a sale.

121. 406 F.2d 260 (2d Cir. 1969), cert. denied, 396 U.S. 1036 (1970).

122. 406 F.2d at 263. The purchaser and seller of the shares was the defendant, Martin Marietta Corp. Martin Marietta was deemed under $\$ 16(\mathrm{~b})$ to be a director of Sperry Rand Corp., the issuer in question, because George Bunker, Martin Marietta's president and chief executive officer, was a director of Sperry Rand and the court held that he had been deputized to represent Martin Marietta on the Sperry Rand board. 406 F.2d at 265-66.

123. 406 F.2d at 266. All the other courts that have considered the issue raised in Feder found the transactions involved to be within the reach of $\S 16(\mathrm{~b})$. See 16 JACOBS, supra note $104, \S 3.03$, at $48-58$ (listing cases). 
case of a director who resigns his directorship before the sale it is possible for both the purchase and sale to have been unfairly motivated by insider knowledge; whereas if the purchase were made prior to the directorship only the sale could be motivated by inside information." ${ }^{124}$ In the first hypothetical the SEC came to the right answer for the wrong reason. This time it is the court.

c. SEC rules. As with pre-insider trades, before 1991 SEC rules never directly addressed the applicability of section 16 (b) to postinsider trades. However, in 1969, in reaction to the Feder holding, the SEC adopted a rule requiring reporting of such trades under section $16(\mathrm{a}),{ }^{125}$ again giving as a justification the desire to provide for disclosure of "all transactions which may be subject to section 16(b)."126 In the SEC's initial 1988 release concerning possible wholesale revision of the section 16 rules, it proposed retaining its then-existing approach to postinsider transactions. As a reason, the SEC stated, "An insider's leaving office does not diminish the ability to develop a plan to purchase and sell or sell and purchase while in possession of inside information." 127 Ultimately, the SEC adopted the current rule 16a-2(b), which, without further explanation, explicitly included postinsider transactions within the reach of both section 16(b) and section 16(a).128 The reasons quoted above $^{129}$ are somewhat vague, but they encompass the reasons suggested here for why Feder-type transactions should be covered. Rule 16a-2(b) will likely stand as settled law, because it is simply an SEC interpretation of the statute, an interpretation fully consistent with prior judicial opinions concerning postinsider trades.

\section{Market-Acquired Options}

\section{The Purchase and Sale of Calls}

Now consider hypothetical C1. On January $1, W$, an officer of $\mathrm{ABC}$ Corporation, purchases 1000 nine-month call options on $\mathrm{ABC}$ shares for $\$ 4$ per option. The exercise price is $\$ 50$, the current market price of $A B C$ shares. On February 1, when the market price of

124. 406 F.2d at 268.

125. See former rule 16a-1(e), 17 C.F.R. § 240.16a-1(e) (1990) (current version at 17 C.F.R. $\S 240.16 \mathrm{a}-2$ (b) (1993)), which in essence required any director or officer who leaves office and engages in any trade within six months of his last trade while in office to report such postinsider trade.

126. Release No. 8574, supra note 106, at 7250 (proposing former rule 16a-1(e)).

127. Initial Release, supra note 7 , at 89,602 .

128. 17 C.F.R. \& 240.16a-2(b) (1993).

129. See text accompanying supra notes 126-27. The SEC presumably intended these reasons to justify the rule it finally adopted as well as its initial proposal. 
$\mathrm{ABC}$ shares has risen to $\$ 60, W$ sells the options for $\$ 13$ each. Should $X$ 's $\$ 9,000$ profit be recoverable by ABC?

a. Application of the principle of decision. W's purchase of options for his portfolio is economically equivalent to purchasing 1000 $\mathrm{ABC}$ shares on a highly leveraged basis, combined with the acquisition of 1000 put options as an insurance policy against the risk that the market price of these shares will drop below their purchase price. ${ }^{130} W$ 's sale of the options is, correspondingly, equivalent to selling the $1000 \mathrm{ABC}$ shares, repaying the leveraging loan, and selling the no-longer-needed insurance policy.

Putting the insurance aside for a moment, we should draw the same inferences concerning the use of inside information from $W$ 's purchase and sale of the calls as we would from a purchase of 1000 shares followed within six months by their sale. We should also expect the same deterrent effect from applying section 16(b) to the paired transactions. ${ }^{131}$ The analysis in Part II demonstrates that, in the absence of the statute, purchases followed within six months by sales contain a larger proportion of purchases motivated by inside information than would officer-and-director transactions generally. The application of section 16(b) to such purchases would deter trading in a way that burdens a larger proportion of transactions that are motivated by inside information than transactions that are not so motivated. At this point in the analysis, therefore, the principle of decision suggests that section 16(b) should be applied to the purchase of call options that are sold within six months.

The insurance aspect of the call options does not change this conclusion. The analysis of the ordinary cash-for-security purchase and sale in Part II relied on the fact that adding shares to a portfolio through purchases based on inside information would dediversify the portfolio. Officers holding these additional shares would sell

130. This equivalence can be seen by considering the following series of transactions that $W$ might alternatively have undertaken: (i) take out a discount loan with a face value of $\$ 5,000$ repayable in nine months (the leverage), (ii) use the proceeds (which, because of the discount, would be somewhat less than $\$ 5,000$ ) to purchase $100 \mathrm{ABC}$ shares (the share purchase) and use his own cash to make up the difference, and (iii) purchase 100 nine-month put options with an exercise price of $\$ 50$ (the insurance). See LORIE ET AL., supra note 26, at 148.

131. The leveraging aspect of the transactions does not change the analysis from that of a simple purchase and sale, as described in Part II. One element of $W$ 's portfolio is the amount of his investment in the safe asset, which, if negative, is called "borrowing." Because funds are fungible, the nearly $\$ 5,000$ implicitly borrowed in connection with the purchase of the calls either reduces $W$ 's net holdings of the safe asset or increases the amount of borrowing associated with the portfolio as a whole. If the change does not suit $W$ 's taste for overall portfolio risk versus expected return, he can make appropriate compensating adjustments. See supra note 57. 
them as the information becomes public because they would not want to bear the increased risk associated with dediversification for longer than necessary. Although the insurance aspect of the calls reduces this increased risk, it far from eliminates it. ${ }^{132}$ Thus, if section 16(b) did not apply, call options purchased on the basis of inside information, like shares purchased on that basis, would be sold as soon as the information becomes public. Therefore, application of the statute to purchases and sales of call options, like its application to simple purchases and sales, would reduce the number of options that the insider would want to purchase on the basis of inside information. The director or officer will know that he will have to bear the risk of holding each option so purchased for the remainder of the six-month period after the information becomes public.

$b$. Court decisions. The legislative history of the Exchange Act reveals that Congress was concerned with the use of options as a basis for trading on inside information. ${ }^{133}$ Starting as early as 1960 some commentators argued that a purchase of a call option followed within six months by its sale should be covered by section 16(b). ${ }^{134}$ No courts, however, have reached that conclusion. ${ }^{135} \mathrm{~A}$

132. In the hypothetical, if $W$ 's January 1 call purchases were in fact motivated by receipt of inside information that had become public by February 1, from there on he runs the risk, if he continues to hold the options, that the price will drop below $\$ 60$. The limit on his losses is $\$ 10$ per share, because the insurance covers losses from any drop in the price of the shares below \$50. But assuming that ABC's future share price is normally distributed and is not exceptionally volatile, a drop that large in a few months is unusual. Thus there is still present most of the riskiness that would be associated with continuing to hold without insurance an equivalent number of shares.

There is also an opportunity cost involved in continuing the insurance after the inside information becomes public. Part of what a buyer pays for when the call is sold is the insurance. The longer the period covered by the insurance, the more the buyer will pay for it. Postponing sale of the option after the information becomes public reduces what will be received for the insurance.

133. See H.R. Rep. No. 1383, 73d Cong., 2d Sess. (1934), reprinted in 5 Legislative History, supra note 87, item 18, at 10-11; S. ReP. No. 792, 73d Cong., 2d Sess. (1934), reprinted in 5 Legislative History, supra note 87, item 17, at 9.

134. Mark R. Beatty, Exchange-Traded Options and Section 16(b): Panacea or Plague for Insider's Short-Swing Profits?, 38 Bus. LAw. 515, 525 (1983); George P. Michael, Jr. \& Barbara A. Lee, Put and Call Options: Criteria for Applicability of Section 16(b) of the Securities Exchange Act of 1934, 40 Notre Dame LAw. 239, 250 (1965); Natalie Garth, Comment, Section 16(b): Measuring Profits Realized in Option Transactions, 1983 ARIz. ST. L.J. 855, 862; Note, Put and Call Options Under Section 16 of the Securities Exchange Act, 69 Y ALE L.J. 868, 874 (1960).

135. The closest case to hypothetical $\mathrm{C} 1$ is Truncale v. Blumberg, 88 F. Supp. 677 (S.D.N.Y.), affd. sub nom. Truncale v. Scully, 182 F.2d 1021 (2d Cir. 1950). Blumberg involved a defendant who, having sold 3000 of his employer's warrants in the preceding six months, received 3000 warrants in December 1945 pursuant to the terms of an employment contract entered into in March 1941. The opinion by Judge Rifkind deals solely with the issue of damages. Judge Medina, in a prior unreported decision, had already ordered summary judgment against the defendant except with respect to damages. See 88 F. Supp. at 678 . One problem with using this case as precedent for a situation like hypothetical $\mathrm{C} 1$ is that a warrant is issued by the issuer corporation itself. Thus the plaintiff in Blumberg was able to 
court addressing this issue would have to decide whether the purchase and sale of the call options constitutes the purchase and sale of an "equity security of such issuer" 136 (the issuer with which the insider is associated). A court could adopt either of two approaches to find that section 16(b) covered the purchase and sale of call options. One approach would be that the purchase and sale of the call options should, for section $16(\mathrm{~b})$ purposes, be considered the purchase and sale of the underlying shares. The other approach would be that the options themselves are "equity securities of [the] issuer" 137 that have been purchased and sold within six months.

The argument that the purchase of a call option should be treated as the "purchase" of the underlying shares is appealing because it corresponds to the correct description of the economic effect of the purchase of an option: a leveraged purchase of shares accompanied by the insurance of an equivalent number of puts. ${ }^{138}$ Moreover, there is precedent for treating what in reality is one kind of security as the equivalent of another kind of security, at least for the purposes of section 16(b). Courts have held that the purchase

avoid the thorny issue of whether the security purchased and sold was "an equity security of such issuer," Exchange Act $\S 16(\mathrm{~b}), 15$ U.S.C. $\S 78 \mathrm{p}(\mathrm{b})$ (1988). See infra notes $138-41$ and accompanying text. It should also be noted that Judge Rifkind concluded as a matter of law that the price paid for the warrants should be considered the fair market value in December 1945. Because the sales during the preceding six months were at a lower price, he found there to be no profits and hence no damages were recoverable. $88 \mathrm{~F}$. Supp. at 678-79.

In another case, Seinfeld v. Hospital Corp. of America, 685 F. Supp. 1057 (N.D. Ill. 1988), the court made clear in dictum that it would find the short-swing purchase and sale of a call option by a statutory insider to be within the reach of $\S 16(\mathrm{~b})$. However, because the defendant was not a $10 \%$ holder immediately prior to the acquisition of the option, as required by Foremost-McKesson, Inc. v. Provident Securities Co., 423 U.S. 232, 250 (1976), the court granted defendant's motion to dismiss. $685 \mathrm{~F}$. Supp. at 1069 . Also, the precedential value of this case, like Blumberg, is limited by the fact that the entity granting the option was the issuer itself.

136. Exchange Act $\S 16(b), 15$ U.S.C. $\S 78 p(b)(1988)$.

137. Exchange Act $\S 16(b), 15$ U.S.C. $\S 78 p(b)(1988)$.

138. The technical legal problem here is how to characterize the purchase of the call as a "purchase," as the term is used in $\S 16(\mathrm{~b})$, of the underlying share. See Note, supra note 134, at 884-85. One approach is to argue that the purchase of the call is a "contract to buy" the share and hence is a "purchase" of the share under Exchange Act $\S 3(\mathrm{a})(13)$, which defines purchase to include "any contract to buy, purchase, or otherwise acquire." Exchange Act $\S 3(a)(14), 15$ U.S.C. $\$ 78 c(a)(13)(1988)$. A call is certainly a contract and it entitles the holder to buy. It can be argued in response, however, that Congress's intention in including the "contract to buy" language in the definition was to recognize that when two parties are each legally obligated to transfer a security at some point in the future, the portfolio effect for both is essentially the same as if the transfer had already taken place. The call, on the other hand is really a unilateral contract of its writer to make an offer to sell a security at a particular price.

A second, ultimately more straightforward, approach is to point to the prefatory phrase of § 3(a), "unless the context otherwise requires," Exchange Act § 3(a), 15 U.S.C. § 78c(a) (1988), and argue that here the context requires that the purchase of a call be treated as a purchase of a share because the two transactions are economic equivalents for purposes of $\S 16(\mathrm{~b})$. 
of a convertible security and the sale of the underlying security after conversion could constitute a paired transaction within the meaning of section $16(\mathrm{~b}) .{ }^{139}$ The courts in these cases focus on whether the sale of the underlying security was within six months of the purchase of the convertible security, and they treat the conversion as a nonevent. ${ }^{140}$ Despite its attractiveness, this approach is untenable unless the courts reverse the doctrine, developed relatively early in the history of section 16(b), that a "purchase" occurs under 16(b) when the purchaser incurs "an irrevocable liability to take and pay for the stock," 141 something that manifestly does not occur at the time a call option is acquired.

The development of this doctrine illustrates the way in which courts have floundered without a central policy-based theory to guide the application of section 16(b). The doctrine's origin is the sensibly decided case of Blau v. Ogsbury. ${ }^{142}$ Ogsbury, the defendant officer and director, gave notice in December 1945 of his election to purchase 10,000 shares pursuant to an option that was part of his employment contract. In accordance with his rights under the option, the defendant postponed paying for the shares until December 1948. The contract made clear that although title and stockholder rights remained in the company pending payment, the defendant was obligated to pay for the shares. The section $16(\mathrm{~b})$ issue arose because in July 1948 the defendant had sold 500 other issuer shares. The critical question for deciding liability was whether the purchase occurred on the date of payment, December 1948 , or on the date of the election of purchase, December 1945. The court decided that the purchase occurred on the date of Ogsbury's election to exercise his right to purchase the shares. The

139. For a discussion of some of these cases, see infra note 190 .

140. See infra notes $188-92$ and accompanying text. The underlying logic of this rule is that the two classes of securities are economic equivalents for $\S 16(\mathrm{~b})$ purposes. The change from one to another in an insider's portfolio is of no significance. If the conversion from inthe-money convertible preferred stock to common stock does not trigger $\S 16(\mathrm{~b})$, logically the purchase and sale of in-the-money convertible preferred should be considered equivalent for $\S 16(b)$ purposes to the purchase and sale of common stock. This logic is not needed to get the purchase and sale of preferred within the reach of $\S 16(\mathrm{~b})$ because convertible preferred shares are themselves clearly "equity securit[ies] of such issuer," Exchange Act $\S 16(\mathrm{~b}), 15$ U.S.C. $\S 78 \mathrm{p}$ (b) (1988), and hence are covered. But the logic applies equally well to the purchase and sale of a call, which arguably is not an "equity security of such issuer." Exchange Act $\S 16(\mathrm{~b}), 15$ U.S.C. $\S 78 \mathrm{p}(\mathrm{b})(1988)$. Any call, as in hypothetical C1, that is exercisable at the share price at the time of purchase and that is sold when the share price is higher is "in the money," that is, its sale price will at least equal the share price at the day of sale less the exercise price.

141. Blau v. Ogsbury, 210 F.2d 426, 427 (2d Cir. 1954); see also Stella v. Graham-Paige Motors Corp., 232 F.2d 299 (2d Cir. 1956).

142. 210 F.2d 426 (2d Cir. 1954). 
rationale was that after December 1945 "for all speculative purposes he owned the stock." 143 Although the court spoke in terms of the "purchase" occurring in December 1945, its decision that section 16(b) does not apply only required the rejection of December 1948 as the purchase date. The court did not explore, because it did not need to, whether the defendant "for all speculative purposes" owned the stock before December 1945. Ogsbury would have served as a more valuable guide for future cases if it instead had concluded that the date of purchase of a share is a date no later than the date on which the insider incurs the irrevocable obligation to take and pay for it.

The effect of the language in Ogsbury was to strengthen the force of language in earlier cases suggesting that the exercise of a stock option constitutes the purchase of the underlying shares. ${ }^{144}$ Because it would be hard to say that the same shares were purchased twice, ${ }^{145}$ these holdings are inconsistent with the idea

143. 210 F.2d at 427.

144. The case that is usually cited as the origin of this doctrine is Park \& Tilford, Inc. v. Schulte, 160 F.2d 984 (2d Cir.), cert. denied, 332 U.S. 761 (1947). Park \& Tilford in fact involved the conversion of convertible preferred stock, which the defendants had apparently held for some time, followed within six months by a sale of the common shares that were received. The court found the conversion and sale to be "a 'purchase and sale' within the statutory language of $\S 16($ b)." 160 F.2d at 987 . It noted that "[d]efendants did not own the common stock in question before they exercised their option to convert; they did afterward." 160 F.2d at 987 . The court in Ogsbury, however, erroneously stated that in Park \& Tilford "we held that the exercise of an option to acquire securities was a 'purchase' within ... $\S 16$ (b)." Ogsbury, 210 F.2d at 427 (emphasis added). The irony of applying the Park \& Tilford principle to call options is that the principle was not followed in conversion cases subsequent to Park \& Tilford in other circuits and that ultimately the Second Circuit itself reversed its position. See infra note 190 and accompanying text.

Steinberg v. Sharpe, 95 F. Supp. 32 (S.D.N.Y. 1950), involved a defendant who exercised an option he had received from the issuer pursuant to an employment contract. The defendant held the option for over two years. There were a number of sales of shares within six months prior to or after the exercise. Judge Medina apparently took it as self-evident that the exercise was a purchase that could be matched against these sales, stating, "There are no disputed issues of fact and the sole question is whether defendant Reuscher enjoyed any profit as a result of the purchase and sale within six months of securities issued by the corporation of which he is an officer." 95 F. Supp. at 32.

There are other pre-Ogsbury decisions that also show the same judicial failure to understand that the point at which speculation begins is the point at which an insider obtains the right to acquire the stock at a predetermined price. In an earlier opinion growing out of the case of Truncale v. Blumberg, 80 F. Supp. 387, 390, 392 (S.D.N.Y. 1948), Judge Medina, citing Park \& Tilford, rejected in dictum the defendant's claim that the time at which an employment contract providing for a future grant of warrants is the "time of purchase" of such warrants. Medina therefore concluded that the time of acquisition of the warrants is the time of $\S 16$ (b) purchase. $80 \mathrm{~F}$. Supp. at 390,392 . Judge Rifkind applied this principle without further comment in the later Blumberg opinion discussed in supra note 135 . Truncale $v$. Blumberg, 88 F. Supp. 677, 679 (S.D.N.Y.), affd. sub nom. Truncale v. Scully, 182 F.2d 1021 (2d Cir. 1950). That opinion involved other defendants who had sold warrants less than six months prior to their receipt. $88 \mathrm{~F}$. Supp. at 678 .

145. Ogsbury, 210 F.2d at 427. 
that the purchase of the option should be considered the purchase of the underlying securities. The rejection of this idea, we will see, makes it difficult to apply section 16(b), in a fashion consistent with its purposes, to the acquisition of an option paired with a variety of other kinds of transactions. The rejection ignores the fact that the way one takes advantage of inside information is to profit from changes in market price. It is the right to acquire stock at a predetermined price that permits a profit from a change in market price, not the obligation to take the stock. ${ }^{146}$

The alternative approach to interpreting section 16(b) to cover the purchase and sale of call options is to argue that the options themselves are equity securities of the issuer. Although amendments to the definition sections of the Exchange Act ${ }^{147}$ and the Exchange Act rules ${ }^{148}$ provide that an option is an "equity security," the question remains, whether it is a security "of" the issuer. The legislative history, not surprisingly, is bereft of any direct evidence of what Congress intended by the phrase "of such issuer." To a securities lawyer, the most natural reading of the phrase is that it refers to equity securities issued by the issuer. This is clearly what is meant by the phrase in most places where it is used throughout the federal securities laws. ${ }^{149}$ Most market-traded options, other than warrants, would not qualify under this reading because they are written by third parties.

It is possible, however, to read the phrase in section 16(b) more broadly as referring to all securities "connected with" or "relating to" an issuer - which reading would include exchange-traded options - and to argue quite sensibly that this alternative reading of the phrase is more consistent with the congressional purpose of preventing the unfair use of inside information. In modern securities markets, an officer or director with positive inside information can just as easily purchase 100 calls, anticipating that in a few months when the information becomes public he will sell the calls and lock in his profits, as he can 100 shares, with a similar anticipa-

146. JenNings ET AL., supra note 12 , at 1393.

147. Section $3(a)(10)$ now defines security to include "any put call, straddle, option or privilege on any security." 15 U.S.C. $\$ 78 \mathrm{c}(\mathrm{a})(10)(1988)$.

148. Rule 3a11-1 includes within the definition of "equity security" any "put, call, straddle, or other option or privilege of buying such a security from or selling such a security to another without being bound to do so." 17 C.F.R. \& 240.3a11-1 (1993).

149. This is the reading advocated by the American Bar Association Task Force on Insider Trading, a group of distinguished securities lawyers. Committee on Fed. Reg. of Sec., supra note 9, at 1110. Because the Task Force concluded that short-swing purchases and sales of options should be subject to a $\S 16(\mathrm{~b})$-type return of profit requirement, it called for an amendment to the language of the statute to cover them. Id. 
tion of sale. As we have seen, ${ }^{150}$ the profits from the purchase and sale of calls will be almost as great as the profit from a similar transaction in shares, and the added portfolio risk will actually be somewhat less. The two kinds of transactions therefore equally implicate the concerns animating section 16(b).

For our hypothetical $\mathrm{C} 1$ both readings accomplish the same result - the return to $\mathrm{ABC}$ by $W$ of his profits from the purchase and sale of the calls. But the second reading is only necessary if one must evade the Ogsbury doctrine that a "purchase" occurs when the insider is irrevocably liable to take and pay for the shares. A frontal attack on the application of that doctrine to the purchase of options would be preferable because, as mentioned above, the doctrine creates a variety of other problems in deciding the reach of section 16(b).

\section{The Purchase of a Call Followed by Its Exercise and the Sale of the Share}

Now consider hypothetical C2. On January $1, V$, an officer of $\mathrm{ABC}$, purchases 200 six-month call options on $\mathrm{ABC}$ shares for $\$ 3$ per option. The exercise price is $\$ 50$, which is the current market price of $A B C$ shares. On June 30 , when the market price is $\$ 60$, he exercises the options and purchases 200 shares at $\$ 50$. On September 15 , when the price is $\$ 65$, he sells the shares. Thus the sale of shares is more than six months after the purchase of the option but less than six months after the exercise of the option. Are there "profits" in this series of transactions that should be recoverable from $V$ by $\mathrm{ABC}$ ?

a. Application of the rule of decision. The purchase of the 200 calls is, we have seen, ${ }^{151}$ the economic equivalent to the purchase, largely funded by a loan, of 200 shares coupled with the acquisition of 200 puts as insurance against the risk that the market price will drop. The exercise of the call is equivalent to the repayment of the loan and cancellation of the insurance.

The first question raised by the hypothetical is whether the purchase of the calls on January 1 could be motivated by the receipt of positive inside information. Clearly the answer is yes. As we saw in Part II, when $V$ receives inside information he will want to add $\mathrm{ABC}$ shares to his portfolio. ${ }^{152}$ Purchasing a call is, in terms of

150. See supra section III.C.1.a.

151. See supra note 130 and accompanying text.

152. See supra section II.A.1.a.iii. 
its effect on $V$ 's portfolio, a method of acquiring an additional share. ${ }^{153}$

Having established that the purchase of shares could be motivated by inside information, the next question is whether the timing of either the sale of the shares or the exercise of the option tells us anything about the probability that the purchase of the option was motivated by the receipt of inside information. The answer here is no. For purposes of our discussion, the timing of the sale of shares - more than six months after the purchase of the calls - does not tell us anything about this probability because the rules of inference we have been exploring are tied to the statutory six-month period. The timing of the exercise of the calls has no probative value for us either, even though it followed the purchase by less than six months. In terms of economic equivalents, the exercise of the calls in fact increases the range of prices over which $V$ is speculating on the 200 shares because it involves the cancellation of the implicit puts. ${ }^{154}$ This moves $V$ 's portfolio in the opposite direction from what someone who purchased calls on positive inside information would wish once the information became public. Such a person would now wish to reverse the dediversification of his portfolio that had occurred at the time he originally received the information.

The last question is whether the exercise of the option itself could be motivated by positive inside information, because, if it could, the sale of the 200 shares less than six months later might suggest a higher probability that the exercise was motivated by inside information. The answer, however, is that the receipt of inside information could not have been the motivating factor in the exercise. In the hypothetical, $V$, having waited until the last moment, is bound to exercise the calls whether or not he has received inside information. Otherwise the call will expire and he will lose his opportunity to purchase at $\$ 50$ shares currently valued by the market at $\$ 60$.

153. If $V$ can borrow infinitely at the safe rate of interest, $r^{*}$, purchasing calls is, compared to the straight purchase of shares, an inferior way of acquiring additional shares. With the purchase of a call, the put that accompanies the share acquisition is, in $V$ 's eyes, overpriced. The market, which does not have $V$ 's positive inside information, views the probability of $\mathrm{ABC}$ shares falling in price below $\$ 50$ as greater than $V$ views that probability. However, legal and economic restrictions on borrowing to purchase stocks in the real world may make the purchase of calls an attractive alternative to the straight purchase of shares.

154. The exercise of a call, in terms of its economic equivalents, also represents the repayment of the implicit loan that largely funded the acquisition of the share when the call was purchased. This fact, however, plays no role in our analysis. Funds are fungible, and $V$, in reaction to both the loan and its repayment, can be expected to make adjustments to suit his taste for risk in his aggregate level of borrowing or net investment in the safe asset. See supra note 131 . 
The answer to the last question may appear to be a clever manipulation of the facts of the hypothetical and not to be generalizable to the situation in which the exercise of the calls occurs at some point prior to their date of expiration. But that is not the case. Assuming that $V$ is a rational investor, he would only exercise the calls prior to their expiration date if he wanted to sell the shares immediately. ${ }^{155}$ To exercise prior to the point at which one wants to sell them is to forgo, with no gain, the insurance that the call provides against the possibility that the share price will drop below the exercise price. Any exercise prior to the expiration of the calls is simply the satisfaction of a necessary precondition for the sale of shares that will inevitably follow immediately thereafter.

The foregoing discussion suggests that when there is a sequence of the purchase of a call, the exercise of the call, and the sale of a share, the focus should be on the dates of the call purchase and the share sale. The timing of the exercise is the earlier of the date of sale or the date of the call's expiration and therefore has no independent significance. One component of a call purchase, in terms of its economic equivalents, is a share acquisition. The other components, the loan and the put, disappear as a result of the exercise. The purchase of the call should therefore be treated as the purchase of a share. If it is followed within six months by a sale, the pair of trades should be covered by section 16(b). If the share sale is more than six months after the call purchase, as in hypothetical $\mathrm{C} 2$, the pair of trades should not be covered.

b. Court decisions. Commentators have suggested three possible ways of characterizing the scenario in hypothetical $\mathrm{C} 2$ in terms of the meaning of the terms purchase and sale under section 16(b). The first characterization, which consistently obtains the results recommended above, is to consider (i) the purchase of the call to be a "purchase" of the underlying shares, (ii) the exercise not to be the "purchase" or "sale" of anything, and (iii) the sale of the shares to be a "sale" of shares. 156 The second characterization is to consider

155. The SEC confirmed this fact empirically in a report on puts and calls that concluded that "when an option holder exercises a call he usually resells the stock he has acquired immediately. Division of Trading Exchs., Securities \& Exch. Commn., Report on Put And Call Options 77 (1961). If the insider can sell the calls in a competitive market, it is in fact always more advantageous for him to do so, rather than to exercise the calls prior to expiration and then to sell the shares. The exercise prematurely cancels the insurance aspect of the calls - insurance for which someone else would be willing to pay. KENNETH GARBADE, SECURITIES MARKETS 381-82 (1982) (concluding that in-the-money calls will not be exercised prior to the expiration date because the price of the options exceeds their intrinsic value).

156. This characterization corresponds to the first approach for bringing the short-swing purchase and sale of a call option, hypothetical $\mathrm{C} 1$, within the reach of $\S 16(\mathrm{~b})$. It has been 
(i) the call purchase not to be the "purchase" of anything for which, in this scenario, there is a matching "sale," (ii) the exercise to be a "purchase" of shares, and (iii) the share sale to be a "sale" of shares. ${ }^{157}$ The third characterization is to consider (i) the calls themselves to be "equity securities of such issuer" 158 and their purchase to be a "purchase" of such securities, (ii) the exercise to be both a "sale" of the calls and a "purchase" of the shares, and (iii) the share sale to be a "sale" of the shares. ${ }^{159}$ Viewed as a whole, the cases dealing directly with stock options tend to support the second and third characterizations. These cases, however, lack a single clear set of reasons, and there exists among them some important authoritative support for the first characterization - the one favored here. At least as important, cases dealing with the closely analogous problem of convertible securities unambiguously support the first approach. All these cases will be discussed below. ${ }^{160}$

One line of cases relevant to the proper choice of characterization deals with the exercise of employee stock options (ESOs). These cases, which will be discussed in more detail later, ${ }^{161}$ uniformly hold that the exercise of an ESO is a "purchase" of the acquired share and hence support the second and third approach. These cases, however, are not exactly on point. The courts deciding them were not faced as conspicuously with the question of whether the acquisition of an option should be treated as a section 16(b) "purchase" because the options at issue were granted to the insiders, not purchased by them.

Another line of cases relevant to the choice of characterization deals with the sale, rather than exercise, of call options acquired more than six months previously. The plaintiffs in these cases argue that the sale of the option should be treated as a simultaneous exercise of the option and sale of the shares. ${ }^{162}$ The rationale is that the

the characterization advocated by Jennings and Marsh in their venerable securities regulation casebook for a number of editions. See, e.g., Richard W. Jennings \& Harold Marsh, JR., Securities Regulation: Cases and Materials 1436-38 (6th ed. 1987).

157. See Beatty, supra note 134, at 525-27.

158. Exchange Act $\S 16(b), 15$ U.S.C. $\S 78 p(b)$ (1988).

159. See Note, supra note 134 , at $876-77$.

160. See infra notes $188-92$ and accompanying text.

161. See infra section III.D.

162. So far, no court presented with this argument has been willing to apply it to the facts of the case before it. See, e.g., Portnoy v. Seligman \& Latz, Inc., 516 F. Supp. 1188 (S.D.N.Y. 1981) (finding that the sale of warrants by insiders to underwriters who converted them and sold the underlying shares is not a 16(b) purchase and sale because the facts suggested no possibility of speculative abuse); Rosen v. Drisler, 421 F. Supp. 1282 (S.D.N.Y. 1976) (hold- 
results of the actual and putative transactions are economically equivalent, because the sale price of the option should approximately equal the difference between the exercise price and the market price of the shares. An insider would go into each transaction with the call and come out without the call but with approximately the same amount of additional cash. Although research reveals no reported case that has adopted this argument, the plaintiffs' rationale in these option sale cases suggests the third characterization of hypothetical $\mathrm{C} 2$, in which the exercise of a call is considered a simultaneous "sale" of the call and "purchase" of the underlying shares. An insider would go into each of the actual and putative transactions with the call and come out with the share but with less cash approximately equal to the exercise price.

The third relevant line of cases - the few that actually deal with calls that were purchased by the insider rather than acquired as employee compensation - presents a more mixed picture. The closest case factually to hypothetical C2 is Morales v. Mapco, Inc. ${ }^{163}$ The defendant, a vice-president of Mapco, purchased warrants for company stock more than six months prior to exercising them. The warrant automatically would have converted into a half share of Mapco on its expiration date. Alternatively, at any point prior to expiration, the holder could exercise the warrant for the exercise price of nine dollars and receive a full share of Mapco. In essence, the warrant was equivalent to a half share of Mapco plus an option, with an exercise price of nine dollars, to purchase another half share. In the month prior to the expiration date, the defendant exercised all of his 3616 warrants and simultaneously sold nine hundred of the shares so acquired.

The district court granted the defendants' motion for summary judgment. The court classified this transaction as "unorthodox" rather than "traditional cash-for-stock." 164 The court concluded as

ing that the sale of options is not a $16(\mathrm{~b})$ purchase and sale when the sale is back to the issuer, the issuer took the initiative to offer to purchase the options, and plaintiffs could not show how the disputed transactions gave rise to the possibility of speculative abuse). The case with a holding most closely analogous to the plaintiff's argument being considered here is Matas v. Siess, 467 F. Supp. 217 (S.D.N.Y. 1976), in which the exercise of an SAR was held to be a $\S 16(\mathrm{~b})$ purchase and sale because it was economically equivalent to the exercise of a stock option and the sale of the underlying shares. However, in Seinfeld v. Hospital Corp. of America, 685 F. Supp. 1057 (S.D.N.Y. 1988), discussed infra text accompanying notes 183-87, the court rejected the whole approach implicit both in Matas and in the plaintiffs' argument being discussed here because the court did not as a general matter view the exercise as a $\S 16$ (b) purchase of the underlying shares. 685 F. Supp. at 1064-65.

163. Morales v. Mapco, Inc., [1974-1975 Transfer Binder] Fed. Sec. L. Rep. (CCH) II 95,094, at 97,875 (N.D. Okla. 1975), revd., 541 F.2d 233 (10th Cir. 1976).

164. [1974-1975 Transfer Binder] Fed. Sec. L. Rep. (CCH) at 97,878. 
a consequence that the applicability of section 16(b) should be determined by a "pragmatic" test ${ }^{165}$ that turns on whether the circumstances provide an opportunity for speculative abuse of inside information. ${ }^{166}$ The court found, for three reasons, that no such opportunity existed and hence that section 16(b) did not apply. The first reason was that the simultaneity of the exercise and sale left no time between the two in which to speculate over inside information. ${ }^{167}$ This reason implicitly treats the exercise as a purchase and, taken alone, tends to support the second and third characterizations of the scenario in hypothetical C2. ${ }^{168}$ The second reason was that for at least a year the market price of the warrants was based on the market price of the Mapco shares, ${ }^{169}$ making the two economic equivalents. ${ }^{170}$ Because this reason does not treat the exercise as a purchase, it tends to support the first characterization, favored here. Because the purchase of the warrants occurred more than six months before the sale of the shares, there was no basis for imposing section 16(b) liability. The third reason was that because the exercise occurred within a month of the expiration date of the warrants and a failure to exercise would have entailed a major economic loss to the defendant, the exercise was essentially involuntary. ${ }^{171}$ This reason also tends to support the first characterization, but the grounds are narrower because the reasoning applies

165. [1974-1975 Transfer Binder] Fed. Sec. L. Rep. (CCH) at 97,878.

166. In Kern County Land Co. v. Occidental Petroleum Corp., 411 U.S. 582 (1973), the Supreme Court embraced the distinction between "traditional cash-for-stock transactions that result in a purchase and sale ... within the six-month, statutory period" and "unorthodox" transactions, ones that are "not ordinarily deemed a sale or purchase" but which arguably fit within broad definitions of these terms under $\S 16(\mathrm{~b})$. 411 U.S. at 593-94. The "traditional" transactions are "clearly within the purview of $\S 16($ b)." 411 U.S. at 593. The Court said, however, that in deciding whether an "unorthodox" transaction is "within the reach of the statute, the courts have come to inquire whether the transaction may serve as a vehicle for the evil which Congress sought to prevent - the realization of short-swing profits based upon access to inside information." 411 U.S. at 594. This way of dealing with unorthodox transactions is known as the "pragmatic" approach. 411 U.S. at 594 n.26. The court gave conversions and dealings in options and warrants as examples of unorthodox transactions. 411 U.S. at 593 n.24.

167. Mapco, [1974-75 Transfer Binder] Fed. Sec. L. Rep. (CCH) at 97,879.

168. The court said that "[h]ad Ross held the stock for any period of time after the exchange, a strong presumption of speculative abuse would immediately exist." Mapco, [19741975 Transfer Binder] Fed. Sec. L. Rep. (CCH) at 97,879. This adds to the suggestion that they regarded the exercise as a purchase. If, however, the court really wanted to treat the exercise as a purchase, the more logical way of dealing with the lack of opportunity for speculative abuse here is to conclude that the purchase and sale are covered by $\S 16(\mathrm{~b})$ but that there are no profits because the value of the cash received is no greater than the value of what was given up - one warrant plus nine dollars.

169. [1974-1975 Transfer Binder] Fed. Sec. L. Rep. (CCH) at 97,878.

170. [1974-1975 Transfer Binder] Fed. Sec. L. Rep. (CCH) at 97,878-79.

171. [1974-1975 Transfer Binder] Fed. Sec. L. Rep. (CCH) at 97,879. The court cites as evidence of the economic necessity of conversion the fact that by the expiration date of the 
only to calls exercised just prior to expiration, not to all "in the money" calls as would the court's second reason.

The Tenth Circuit reversed the district court decision in an opinion that deals remarkably ineffectively with the district court's three reasons. The court of appeals emphasized that the defendant had to pay cash for the shares, not just surrender the warrant. ${ }^{172}$ The court did not indicate why the payment of cash was important other than to differentiate the case factually from some of the convertible security cases, discussed below, ${ }^{173}$ in which the conversions were not found to be purchases. The court of appeals stated that the transactions had the possibility of speculative abuse, but it did not explain how except by saying that "the warrant holder could exercise a warrant and pay $\$ 9.00$ with full awareness of the current market quotations on Mapco stock." 174 The court stated that "[t]he warrants were not the economic equivalent of the stock because the warrants carried no equity ownership," 175 but it did not explain why equity ownership should be a factor in deciding whether two securities are economically equivalent for section 16(b) purposes. The court of appeals ignored the involuntariness question.

Miller v. General Outdoor Advertising Co. ${ }^{176}$ deals directly with the question of whether the acquisition of a call is a "purchase" that can be matched against the sale of shares. In October 1962 the defendant was granted a call on approximately fifteen to twenty percent of the outstanding shares of the Alleghany Corporation by a major shareholder in Alleghany. The grant was part of a contract in which the defendant purchased outright a similar number of shares. The call was to expire on May 31, 1963; but, pursuant to amendments on May 29, June 28, and July 29, the expiration date was extended, ultimately to October 15,1963 . On July 1,1963 , the defendant contracted to sell a substantial number of Alleghany shares subject to certain approvals by the shareholders of the purchasing corporation. Alleghany sued under section 16(b), claiming that the June 28 extension of the call was a "purchase" and the July 1 contract to sell was a "sale" of Alleghany shares. ${ }^{177}$ The district court

warrants, over $98 \%$ had been converted. [1974-1975 Transfer Binder] Fed. Sec. L. Rep. $(\mathrm{CCH})$ at 97,879 .

172. Morales v. Mapco, Inc., 541 F.2d 233, 235 (10th Cir. 1976).

173. See infra notes $190-92$ and accompanying text.

174. 541 F.2d at 236 .

175. $541 \mathrm{~F} .2 \mathrm{~d}$ at 236 .

176. 223 F. Supp. 790 (S.D.N.Y. 1963), revd., 337 F.2d 944 (2d Cir. 1964).

177. 223 F. Supp. at 792. 
granted the defendant's motion for summary judgment because it did not believe either that the acquisition of the call was a "purchase" of Alleghany shares ${ }^{178}$ or that the call was itself an equity security of such issuer. ${ }^{179}$

The Second Circuit reversed the district court's order, stating that the complexity of the factual pattern made a trial more prudent. ${ }^{180}$ The Second Circuit observed that

since this is the first case to raise the difficult and far-reaching question of whether the acquisition of a call may be a "purchase" of an "equity security" under Section 16(b), it falls within that twilight zone where full development of the facts is necessary to decide whether the transactions involved were susceptible to the type of speculation the section seeks to eliminate. ${ }^{181}$

Thus General Outdoor Advertising explicitly leaves the door open in the crucial Second Circuit for the adoption of the first characterization - that is, that the purchase of the call, not the exercise, constitutes the purchase of the underlying shares. ${ }^{182}$

The final case is Seinfeld v. Hospital Corp. of America. ${ }^{183}$ The facts of this case do not closely resemble hypothetical $\mathrm{C} 2$, but the court in dictum wholeheartedly endorsed the concept that it is the acquisition of the option, not its exercise, that constitutes the section 16(b) "purchase." In Seinfeld, the defendant was a corporation attempting to acquire the issuer. It obtained from the issuer, pursuant to a merger agreement, a "lock-up" option for more than ten percent of the issuer's shares. Within six months, the defendant re-

178. 223 F. Supp. at 793.

179. $223 \mathrm{~F}$. Supp. at 795 . The court left open the possibility that it would have ruled differently if the call had been transferable. $223 \mathrm{~F}$. Supp. at 795 . The distinction between characterizing an acquisition of a call as a "purchase" of shares and characterizing the call itself as "an equity security of the issuer," Exchange Act $\S 16(b), 15$ U.S.C. $\S 78 p(b)(1988)$, is merely semantic if, using the second characterization, a court is willing to match the purchase of a call against the sale of a share.

180. Miller v. General Outdoor Advertising Co., 337 F.2d 944, 947 (2d Cir. 1964).

181. 337 F.2d at 948.

182. Jennings and Marsh suggest that the Second Circuit reversed after realizing that the courts had been wrong for 30 years in finding an exercise to be a purchase in the employee stock option cases. Jennings \& MARSH, supra note 156, at 1438 . They note wryly that "[the court] did not suggest what further 'facts' it thought were going to throw any more light on this problem." Id. The extent to which the Second Circuit's opinion can be used as support for the first characterization of hypothetical $C 2$ is somewhat weakened, however, by the fact that the contract granting the defendant the call also granted the other party a put on an equal number of shares at an equal price. $337 \mathrm{~F} .2 \mathrm{~d}$ at 946 . If it were not for the fact that the transaction involved a large control block of shares and the fact that the put expired after the call did, this pairing of a call and put would virtually guarantee the acquisition of the shares by the defendant: a market share price above the exercise price would guarantee an exercise of the call and a market share price below the exercise price would guarantee an exercise of the put.

183. 685 F. Supp. 1057 (N.D. Ill. 1988). 
linquished its right to the option in return for $\$ 200$ million in cash, the merger having not been consummated because of the appearance of a higher-paying suitor. The court held that this was an orthodox transaction - the option was an equity security that was acquired for value and relinquished for value - that should be treated under the "objective approach" applied to traditional "cashfor-stock" transactions. ${ }^{184}$ However, because the defendant was not a ten-percent holder when it acquired the option, as required by Foremost-McKesson, Inc. v. Provident Securities Co., 185 the court granted defendant's motion to dismiss. ${ }^{186}$

The plaintiff tried to avoid this outcome by arguing that the sale of an option is an "unorthodox" transaction that should be treated under the "pragmatic" approach. The plaintiff argued that under this approach the transaction should be treated as a simultaneous exercise of the option and sale of the underlying shares because the economic effects of this putative pair of transactions and the actual one are the same. Obviously underlying this argument was the premise that the exercise of an option is a section 16(b) "purchase." In response to this argument, the court stated that even if it used the pragmatic approach and accepted the idea that the option sale constituted a simultaneous exercise of the option and sale of the underlying shares, it would disagree with that premise and therefore would not have found liability:

Virtually all courts to consider the issue have held that "an exercise of a[ ] [call] option is a purchase of the underlying stock for purposes of $\S 16(\mathrm{~b})$." Thus, according to these cases, if a person exercises an option for stock and then, within six months, sells the stock, he is liable under $\S 16(\mathrm{~b}) \ldots$

This judicial rule cannot withstand careful analysis. A person who acquires a call option acquires the right to purchase the underlying stock at a given price. If the price of the stock subsequently rises and the person exercises the option and then sells the stock, the "profit" he earns represents the "swing" in the price, not between the date of exercise of the option and later sale of the stock, but rather between the time he originally purchases the option and the time he sells the stock. ${ }^{187}$

The final line of reported cases relevant to the characterization of hypothetical $\mathrm{C} 2$ deals with the conversion of a convertible security. Call options and convertible debentures share much in com-

184. 685 F. Supp at $1062-63,1069$.

185. 423 U.S. 232, 250 (1976).

186. 685 F. Supp. at 1069.

187. 685 F. Supp. at 1065-66 (citations omitted) (quoting Beatty, supra note 134, at 518). 
mon. A senior security - a debenture or preferred share - that can be converted into one share of common stock is economically equivalent to the same senior security without the conversion privilege combined with a call option on one share of common stock with an exercise price equal to the value of the senior security. ${ }^{188}$ Assuming they are both "in the money," the market price of a senior security convertible into one share and the market price of a regular call option will each move up or down approximately one dollar for every dollar change up or down in the market price of the underlying shares with which they are associated.189 The conversion of the convertible senior security and the exercise of the call each involve giving up something of value - the rights associated with being a holder of the simple senior security in one case and cash in the other - that has very different risk and return characteristics from the share of common stock that is received. Thus, if we cut through form to economic substance, we should treat convertible securities and call options the same in our section 16(b) analysis. The scenario in which an insider purchases a convertible security, converts it, and sells the underlying shares is essentially identical to the scenario in which the insider purchases a call, exercises it, and sells the underlying shares, at least in terms of the factors that should count for a section 16(b) analysis: there is no difference in the speculative nature of the item initially purchased or in the nature of the act that results in the acquisition of the underlying shares.

Cases dealing with the conversion of convertible securities present a much clearer picture than the cases dealing directly with call options. In the scenario most analogous to hypothetical $\mathrm{C} 2$ - the insider purchases a convertible security, converts it when it is "in the money," and sells the underlying shares - the cases do not consider the conversion a "purchase" and hence do not apply section 16(b) if the convertible security purchase and share sale are separated by more than six months. ${ }^{190}$ In Blau v. Lamb, the key

188. To exercise this call, the owner must pay a price; he must give up the senior security. Nancy L. Jacob \& R. Richardson Pettit, Investments 608-09 \& fig. 19-15 (2d ed. 1988).

189. GARBADE, supra note 155 , at 378 (noting that a call that is "in the money" will have an intrinsic value equal to the excess of the stock price over the option's exercise price).

190. The line of cases addressing this question starts, unpromisingly, with the early case of Park \& Tilford, Inc. v. Schulte, 160 F.2d 984 (2d Cir.), cert. denied, 332 U.S. 761 (1947), discussed supra note 144, in which the Second Circuit held the conversion of convertible preferred shares to common to be a $\S 16($ b) "purchase." 160 F.2d at 987 . As other circuits began to confront the issue, however, they came to the opposite conclusion and found that the conversion was not a purchase, although each case was arguably distinguishable from Park \& Tilford. See, e.g., Petteys v. Butler, 367 F.2d 528, 537-38 (8th Cir. 1966), cert. denied, 385 U.S. 1006 (1967) (involving a case in which the convertible preferred was being called for 
case reaching this conclusion, the Second Circuit, reaching the very heart of the matter, reasoned that because the appreciation in the value of the original investment in the preferred continued to be at risk after the conversion, the conversion could not afford the defendants "opportunities to realize a trading gain based on speculative judgment exercised when they purchased [the preferred]." 191 The court therefore concluded that "in cases like the present involving the purchase of a convertible security and its subsequent conversion, the issue should be whether the underlying security has been sold within six months from the acquisition of the convertible security." 192 Although the courts have not seen it, this reasoning is equally compelling in the case of the exercise of a stock option.

c. SEC rulemaking. As discussed in connection with the hypothetical C1, before the 1991 rule revisions the SEC largely avoided the issues of how to treat the acquisition of an option and its exercise under section 16(b) and explicitly left the resolution of these issues to the courts. ${ }^{193}$ The SEC apparently did not like the results, which it described in 1988 as "inconsistent."194 In 1988, therefore, the SEC proposed a comprehensive framework for dealing with options and other "derivative securities," 195 the ownership of which would be treated as "indirect ownership of the underlying equity securities."196 As adopted, new rule 16a-4(a) provides that "both

redemption at the time of conversion); Blau v. Max Factor \& Co., 342 F.2d 304, 308-09 (9th Cir.) (involving a conversion between stocks of similar investment risk), cert. denied, 382 U.S. 892 (1965); Ferraiolo v. Newman, 259 F.2d 342, 345-46 (6th Cir. 1958), cert. denied, 359 U.S. 927 (1959) (addressing a case in which the convertible preferred was called for redemption at the time of conversion). The Second Circuit essentially reversed itself in 1966 in Blau v. Lamb, 363 F.2d 507 (2d Cir. 1966), cert. denied, 385 U.S. 1002 (1967), holding that the conversion of convertible preferred shares into common shares less than six months after the acquisition of the convertible preferred did not constitute a sale under $\S 16($ b). 363 F.2d at 526 .

In Heli-Coil Corp. v. Webster, 352 F.2d 156 (3d Cir. 1965), the Third Circuit held that a conversion involved both a sale of the convertible debentures given up, which had been purchased less than six months before, and a purchase of the common shares received. 352 F.2d at 161 . The impact of this contrary holding is significantly lessened by the court's finding that the sale resulted in no profit because the value of what was given up - the debenture plus the conversion right - just equaled what was received in return. 352 F.2d at 16768 .

Blau v. Lamb was essentially codified with the 1966 amendment to former rule 16b-9(a), eliminating the issue as a subject of contention in the courts. See 17 C.F.R. \& 240.16b-9(a) (1990) (current version at 17 C.F.R. § 16b-6(b) (1993)).

191. 363 F.2d at 522 .

192. 363 F.2d at 525 .

193. See supra notes $125-29$ and accompanying text.

194. Initial Release, supra note 7 , at 89,609 .

195. Rule 16a-1(c) defines derivative securities to mean, subject to certain exceptions, "any option, warrant, convertible security, stock appreciation right, or similar right with an exercise or conversion privilege at a price related to an equity security, or similar securities with a value derived from the value of an equity security." 17 C.F.R. \& 240.16a-1(c) (1993).

196. Initial Release, supra note 7 , at 89,609 . 
derivative securities and the underlying securities to which they relate shall be deemed to be the same class of equity securities." 197 With this bold and clearly correct move, the SEC embraced the first characterization of the scenario in hypothetical $\mathrm{C} 2$ : $V$ 's purchase in January of the 200 call options is equivalent to a "purchase" of the underlying $\mathrm{ABC}$ shares. The exercise in June is a nonevent for purposes of section 16(b) because it leaves unchanged the total number of $\mathrm{ABC}$ equity securities held by the insider. The sale of the shares in September, then, is a "sale" of securities. Because the sale followed the purchase by more than six months, there would be no liability. ${ }^{198}$

In comparison to the existing judicial interpretations of the statute, which were largely developed without the benefit of SEC input, the new rules concerning call options expand the reach of section 16(b) to cover some transactions that at least arguably were not covered before and contract its reach to exempt some that at least arguably were covered before. Correct as these changes may be, we can expect the new rules to be challenged in the courts on both fronts.

The challenge by defendants caught by the expansion in section 16(b)'s reach will probably fail. An example of this broadened scope would be a variation of hypothetical $\mathrm{C} 2$ : everything is the same except that on December 1, a month prior to $V$ 's purchase of the calls, $V$ sold $200 \mathrm{ABC}$ shares for sixty dollars. Under the approach suggested by existing judicial interpretations, there would be no purchase within six months of the December 1 sale because $V$ was not irrevocably committed to take the $\mathrm{ABC}$ shares until June $30 .{ }^{199}$ Under the new rules, the January 1 purchase of the calls would be matched with the December sale of shares. We have seen that section $16(\mathrm{~b})$ has been liberally interpreted in other con-

197. 17 C.F.R. § 240.16a-4(a) (1993).

198. As discussed in the text, this result appears to follow directly from rules $16 \mathrm{a}-4(\mathrm{a})$, 16a-1(c) (discussed supra note 195), and 16a-1(d), which define an option to be a "derivative security" and which define a derivative security relating to an issuer to be, in the language of the statute, "an equity security of such issuer." 17 C.F.R. $\S 240.16 a-1$ (c) to (d) (1993).

A more complex set of definitions and exemptions, needed to cover other scenarios involving derivative securities, makes the steps more explicit, however. Rule 16(a)-1(b) defines a call equivalent position to be a derivative security position, including a call option, that "increases in value as the value of the underlying equity increases." 17 C.F.R. $\$ 240.16 a-1$ (b) (1993). Rule 16b-6(a) provides that the establishment or increase in a call equivalent position "shall be deemed a purchase of the underlying security." 17 C.F.R. $\$ 240.16 b-6$ (a) (1993). Rule 16b-6(b) exempts from $\S 16(\mathrm{~b})$ the closing of a derivative security position as a result of an exercise. 17 C.F.R. $\S 240.16 b-6$ (b) (1993).

199. See Blau v. Ogsbury, 210 F.2d 426, 427 (2d Cir. 1954). 
texts. ${ }^{200}$ The statutory language is malleable enough that it could be interpreted to cover a third-party call option as "an equity security of such issuer" 201 and to permit a "match" when there is a sale of one type of such security - the shares - and the purchase of a closely related type - the calls. ${ }^{202}$ It would be relatively easy for a court to see a close parallel between, on the one hand, a sale of shares at $\$ 60$ and their repurchase a month later for $\$ 50$ and, on the other hand, a share sale for $\$ 60$ followed by a purchase of the calls at a $\$ 50$ exercise price: in each case the insider has avoided the $\$ 10$ loss and from a speculative point of view largely or completely returned to her original position. Courts pay less deference to agency rules constituting statutory interpretation than they pay to rules based on the statutorily delegated power of exemption, but courts do show enough deference to agency interpretations that they are likely to uphold these expansions. ${ }^{203}$

The challenge by plaintiffs that the new rules improperly contract section 16(b)'s reach has a better chance of success, even though the provisions involved are based on statutorily delegated powers of exemption. The problem is not with the overall scheme itself, which is clearly justifiable. The problem is with the SEC's justifications. The justifications provided by the SEC in its rule revision releases relating to call options have two basic thrusts. One thrust is that a determination of the reach of the statute should be based on the opportunity to use inside information to profit from changes in share price, ${ }^{204}$ which opportunity begins at the time that the insider acquires the right to purchase a security at a fixed price. ${ }^{205}$ The other thrust is that a failure to permit the matching of transactions in derivative securities against transactions in the underlying shares will permit evasions of section 16(b).206 These propositions by themselves, while absolutely correct, do not lead

200. See supra section III.B.1.c.

201. Exchange Act § 16(b), 15 U.S.C. \& 78p(b) (1988).

202. There is precedent for matching two related types of equity securities. See Gund v. First Fla. Banks, Inc., 726 F.2d 682 (11th Cir. 1984) (matching the sale of convertible debentures with the purchase of common stock). Ironically, the correct principle that two related types of equity security should be matched was misapplied in this case because the convertible securities were not "in the money" and so their trading price was not primarily determined by the trading price of the underlying shares. See Daniel B. Bogart, Note, Mismatching Convertible Debentures and Common Stock Under Section 16(b), 1985 DUKE L.J. $1057,1073$.

203. See supra note 117.

204. Initial Release, supra note 7, at 89,611 .

205. Exchange Act Release No. 28,869, [1990-1991 Transfer Binder] Fed. Sec. L. Rep. (CCH) q 84,709, at 81,258 (Feb. 8, 1991) [hereinafter Implementing Release].

206. Initial Release, supra note 7 , at 89,612 . 
inevitably to the conclusion that a call purchase is the acquisition of indirect beneficial ownership in the underlying shares and that its exercise is consequently a nonevent that deserves an exemption. ${ }^{207}$

A scenario like hypothetical $\mathrm{C} 2$ raises the traditional suspicion that the insider has cleverly evaded section 16 (b) by using a call option to stretch out the time between purchase and sale. The SEC's justifications do nothing to eliminate this suspicion. Thus, a court facing the new rules might feel constrained by the statutory scheme to adopt the third rather than the first characterization of the hypothetical. Under this characterization, the call purchase in January is the purchase of an equity security, the exercise in June is its sale and the purchase of another equity security (the share), and the sale of the share in September is another such sale. ${ }^{208}$ Each of the paired security purchases and sales would constitute prohibited short-swing transactions under section 16(b), and they would arguably generate recoverable profits: ten dollars for the first pair of transactions and five dollars more for the second.

Another traditional suspicion raised by a scenario like hypothetical C2 - a suspicion the SEC's justifications do not eliminate - is that there could be insider mischief at the time the insider exercises the option. Marc Steinberg and Daryl Landsdale, for example, have raised this suspicion:

The increased potential for abuse under the new regulatory scheme comes from the ability of insiders to exercise options and sell the underlying securities immediately, as long as the option has been held for at least six months. . . . For example, upon learning bad news, an insider holding the derivative security for six months can immediately exercise the option and sell the underlying securities before such information is made public, thereby taking advantage of nonpublic information for his or her personal gain. Section 16 was enacted to prevent this type of transaction. ${ }^{209}$

207. The SEC suggested that exercise is in part a nonevent because the insider "realizes no profit at the time of exercise," and the profit occurs "at the time the underlying security is sold." Reproposing Release, supra note 109 , at 80,390 \& n.87. This is true but irrelevant. The new rules also provide that $\S 16(\mathrm{~b})$ does cover a share purchase followed within six months by the purchase of a put option and the sale of the shares more than six months after their purchase. 17 C.F.R. $\$ 240.16 b-6$ (a) (1993); see infra notes 222-26 and accompanying text. Yet, there is no realization of profit within six months in that scenario.

The SEC also stated that "the exercise does not change the opportunity to realize a profit." Implementing Release, supra note 205 , at 81,259 . That is also true but it is not by itself a persuasive reason to provide an exemption that would permit an insider like $V$ to keep his profits if he otherwise would not be able to do so.

208. This approach would also permit a court to avoid the discomfort of breaking with the well-established Ogsbury doctrine. See supra notes 142-46 and accompanying text.

209. Steinberg \& Landsdale, supra note 12, at 65 (emphasis added). 
A court sharing these suspicions would again be inclined to embrace the idea that the exercise of a call option is a sale of the call and a purchase of the underlying security. The argument would be that the exercise is a transaction "within the purpose of [section 16(b)]" 210 and therefore its exemption is outside the powers delegated to the SEC under section 16(b).

These suspicions linger because the SEC, while demonstrating conclusively how transactions involving derivative securities present opportunities for insider profits akin to those available from transactions in the underlying securities, has not successfully articulated how the statutory six-month cutoff should fit into its new larger vision of section 16(b). In order to overcome these suspicions, the SEC needs to acknowledge three points derived from the model in Part II. First, section 16(b) is aimed only at the abuse of inside information at the time of the first of the paired transactions. Second, section 16(b) deters transactions based on inside information by forcing the insider who does engage in such a transaction to suffer the risk of portfolio dediversification for six months. A longer period of time would discourage an increasing number of legitimate transactions without burdening any more transactions based on inside information. Third, purchase and sale should be defined in terms of when this change in portfolio risk is assumed and when it is relinquished. The exercise of a call option does not significantly change portfolio risk and so it should not be considered either a purchase or a sale.

If the courts were to adopt the third characterization of the C2 hypothetical by overturning the exemption for exercises but otherwise approving the proposed scheme for market-purchased call options, one might conclude that their approach, while not representing an entirely consistent vision of section $16(\mathrm{~b})$ in economic terms, does no real serious harm. We would not significantly undermine our system of managerial incentives or work any real unfairness if we were to burden insider acquisitions of call options and not burden their near equivalents - leveraged purchases of the underlying securities. But we cannot avoid this issue so easily. The same issue arises with employer-granted employee stock options, discussed later, ${ }^{211}$ and the effect of these burdens on managerial incentives is much greater in that context.

210. Exchange Act § 16(b), 15 U.S.C. § 78p(b) (1988).

211. See infra section III.D.1.a. 


\section{The Purchase of a Share Followed by the Purchase of a Put}

Now consider hypothetical C3. On January $1, U$, an officer of $\mathrm{ABC}$, purchases $500 \mathrm{ABC}$ shares for $\$ 50$ per share. On March 1 , when the market price of $\mathrm{ABC}$ shares has risen to $\$ 60, U$ purchases, for $\$ 4$ each, 500 nine-month put options with an exercise price of $\$ 60$. On December 1 , when the market price is also $\$ 60, U$ 's put options expire unexercised and he sells the 500 shares. Are there "profits" in this series of transactions that should be recoverable from $U$ by $\mathrm{ABC}$ ?

a. Application of the principle of decision. The share purchase on January 1 adds $500 \mathrm{ABC}$ shares to $U$ 's portfolio. The put purchase on March 1 is economically equivalent to a sale of 500 shares that are to be delivered and paid for on December $1^{212}$ coupled with a call option for 500 shares exercisable at $\$ 60$ expiring December 1.213 The analysis in Part II suggests that purchases followed within six months by sales would, in the absence of the statute, include a larger proportion of share purchases motivated by inside information than officer-and-director transactions generally. Consequently, putting aside the call option aspect for a moment, the same should be true of purchases of shares followed within six months by purchases of puts. Therefore, as with the application of section 16(b) to purchases followed within six months by sales, the application of section 16(b) to share purchases followed within six months by puts purchases will burden a larger proportion of share purchases based on inside information than potential purchases not so based. Thus, at least before considering the call option aspect of

212. The delayed delivery date is irrelevant for our analysis because the sale price is the market price on March 1 and becomes fixed on that date. Ignoring dividends and the time value of money, adjustments included in the market price of the put, the economic effect on $U$ 's portfolio of delivery on December 1 is the same as if $U$ delivered the shares on March 1 . If $U$ wants cash on March 1, he can borrow money on March 1 and repay the loan on December 1 with the proceeds from the sale of shares.

213. If $U$ had no $\mathrm{ABC}$ shares, the purchase of 500 puts would be equivalent to a short sale of 500 shares and the call option aspect would serve as insurance against the risk that the price of ABC shares would exceed $\$ 60$ on September 1 . Here, however, $U$ owns at least 500 ABC shares. Actual short sales by directors, officers, and $10 \%$ holders are prohibited by $\S 16$ (c) of the Exchange Act. 15 U.S.C. $\S 78 p(c)$ (1988). New rule $16 c-4$ provides an exemption from $\S 16(\mathrm{c})$ for establishing or increasing a put equivalent position so long as the number of puts does not exceed the number of underlying shares owned by the insider. 17 C.F.R. $\S 240.16 c-4$ (1993). This exemption implies that an insider does violate $\S 16(c)$ when she purchases more put options than she owns underlying shares, but nothing in the statute, which by its terms makes unlawful a statutory insider selling an equity security "if the person selling . . . does not own the security sold," 15 U.S.C. $\S 78 \mathrm{p}(\mathrm{c})(1988)$, or in the $\S 16$ rules, directly provides that such a put purchase is a violation. Rule $16 \mathrm{~b}-6(\mathrm{a})$ provides that "the establishment or increase in a put equivalent position shall be deemed a sale of the underlying securities," but it is limited by its terms to $\S 16$ (b). 17 C.F.R. $§ 240.16$ b-6(a) (1993). 
the put, the principle of decision would suggest that section 16(b) should be applied to purchases of shares followed within six months by purchases of puts. ${ }^{214}$

This conclusion is ultimately not altered if we take into account the call option aspect of the put purchase. Because in the scenario that is economically equivalent to hypothetical C3 $U$ will own at least $500 \mathrm{ABC}$ shares immediately prior to performing the required delivery on December 1, he will not need to go into the market and purchase shares in order to perform, and therefore he will not face the risk of losing money if the market price of $\mathrm{ABC}$ shares on that date exceeds $\$ 60.215$ Rather than serving as insurance against a risk of loss, the implicit call here constitutes continued speculation in the price of $\mathrm{ABC}$ shares. Compared to continued ownership of the 500 shares, however, the range of share prices over which speculation occurs is significantly narrowed. By purchasing the puts, $U$ is only speculating over the range of prices above $\$ 60$ and not over the full range of possible share prices.

In order to analyze whether section 16(b) should apply to share purchases followed by put purchases, we first need to understand how the question is dependent on whether section 16(b) applies to share purchases followed by share sales. If we were operating in a world in which section 16(b) applied to neither class of paired transactions, $U$ would never rationally choose on March 1 to purchase 500 puts over the alternative of a straight sale of 500 shares - assuming, as in most financial models, that he believes share prices are normally distributed. This is evident if we consider the three possible motives for either buying puts or selling shares: raising cash, profiting from the receipt of negative inside information, or reversing a dediversification caused by an earlier share purchase based on receipt of positive inside information. ${ }^{216}$ In each case, $U$ 's interests are, in the absence of section 16(b), better served by a straight sale of $\mathrm{ABC}$ shares.

If raising cash is $U$ 's sole motivation, he will not have altered his evaluations of the expected returns, variances, and covariances of

214. The discussion assumes that the exercise price of the puts is the market price of the shares on the date that the puts were purchased.

215. If the market price of $A B C$ shares on December 1 is, for example, $\$ 70$, delivery of each share involves an opportunity cost of $\$ 70$ for which he was only compensated $\$ 60$. But the $\$ 10$ "loss" is no more a loss than if delivery were on March 1 . It simply represents the risk inherent in any sale that the price may go up in the future.

216. The assumption here, as in Part II, is that $U$ will not be motivated to change his portfolio on March 1 as the result of the receipt of new information also available to other investors because the price will adjust so quickly to reflect the information that $U$ will want the same portfolio as he did before. See supra text accompanying note 54 . 
the available risky securities. Therefore, as a rational investor, he would not wish to change the proportions of his holdings in the available risky securities. ${ }^{217} \mathrm{He}$ would be able to raise cash without making such a change by engaging in a proportionate straight sale of his holdings in each of the available risky securities, including $\mathrm{ABC}$ shares. The purchase of 500 puts would be an alternative, but less satisfactory, way of raising cash. With the puts, $U$ can borrow $\$ 3,000$ secure in the knowledge that on September 1 the proceeds from a sale of the shares would be at least sufficient to repay the principal of the loan. Part of what $U$ is paying for in a purchase of puts, as compared to a straight sale of shares, is the continued speculation for six months in $500 \mathrm{ABC}$ shares over the range of prices exceeding $\$ 60$. This, in turn, changes his proportionate holdings of the available risky securities, something he does not wish to do since, based on his evaluations, his original proportions were optimal.

If $U$ receives negative inside information concerning $\mathrm{ABC}$ and hopes to profit from it - the second possible motivation - $U$ could again choose either to purchase puts or to engage in a straight sale of a certain number of shares. But again the call-option aspect of the puts - the difference, in terms of economic equivalents, between a put purchase and a share sale - raises problems. A call exercisable at $\$ 60$ has some value to $U$ because, in assessing the probable future price of $\mathrm{ABC}$ shares, $U$ will predict that the price might exceed $\$ 60$. But if $U$ possesses negative information not possessed by the market, the market will view the probability that the price will exceed $\$ 60$ as greater than $U$ views that probability. Implicitly, then, what $U$ would pay for the call when he purchases the puts at the market price would exceed his estimation of the call's value. $^{218}$

$U$ 's third possible motivation is the desire, once the positive inside information that he received earlier becomes public, to reverse a dediversification caused by the purchase of shares on the basis of that information. The way to fully rediversify is simply to sell the same number of shares as were purchased at the time the inside information was received. A purchase of puts only lessens the impact of, rather than fully reverses, the dediversification; this is again

217. See supra section II.A.3.a.

218. In an efficient market the price of a call is dependent upon the market's determination, based on all available information, of the price, the dividend, and volatility of the underlying security. Robert A. Strong, Speculative Markets 100-02 (1989). Hence, U's knowledge of negative inside information allows him to form a more accurate assessment of the value of a call than the market's. 
because, in terms of the puts' economic equivalents, the sale of shares is coupled with an implied call on ABC shares. If, for example, the purchase of the 500 shares on January 1 were based on inside information, a purchase of 500 puts on March 1 after the information becomes public would still leave $U$ speculating over part of the possible price range for $500 \mathrm{ABC}$ shares. According to the analysis in Part II, $U$ would rather not bear the risk of that speculation in his portfolio.

If, however, we were operating in a second world in which section 16(b) applies to share purchases followed by share sales (as it clearly does), but not to share purchases followed by put purchases (the issue before us), the purchase of the puts by $U$ would be perfectly rational. For each of the three possible motivations, the purchase of puts allows $U$ partially to accomplish the same thing as a straight sale would while avoiding the penalty that section $16(\mathrm{~b})$ would impose on a straight sale. The puts purchase alters the portfolio in the same direction as a straight sale, but it only lessens rather than eliminates speculation with respect to the 500 shares. The same officers who in a first world without section 16(b) would be motivated to engage in straight sales would, in a second world in which section 16(b) applies to share purchases followed by straight share sales but not to share purchases followed by put purchases, be motivated instead to purchase puts. The three possible motivations, which arise from factors not related to the existence or reach of section 16(b), should have the same relative frequency in both worlds. Therefore, in both worlds we should be able to draw from the length of time between the first and second transactions the same inferences as to which motivation was at work. We established in Part II that in a world without section 16(b), sales to raise cash or in response to negative inside information might occur at any point after a purchase, but sales to reverse a dediversification caused by a purchase based on inside information will almost certainly occur within six months of the purchase. We therefore concluded that share purchases followed within six months by share sales contain a larger proportion of purchases motivated by receipt of inside information than officer-and-director transactions generally. ${ }^{219}$ In the second world, the same will be true of share purchases followed within six months by put purchases. Thus, according to the principle of decision, applying section 16(b) to share purchases followed within six months by put purchases is desirable

219. See supra section II.C.2. 
because it would burden a larger proportion of potential share purchases motivated by inside information than purchases not so motivated. Failing to apply section 16(b) to this class of transactions would provide officers and directors considering purchasing shares on the basis of inside information a way of partially avoiding the sting of section 16(b) and hence would lessen the statute's effectiveness.

b. Court decisions. No reported case has ruled on the question whether a share purchase followed within six months by a put purchase is covered by section $16(\mathrm{~b})$. The issue, obviously, is whether the purchase of the puts can be considered a "sale" of the underlying shares to be matched against the share purchase. ${ }^{220}$ The argument that it should be considered a sale exactly parallels the argument above that the purchase of a call should be treated as the purchase of share. Acceptance of that argument, however, again depends on the reversal of the Ogsbury doctrine that a share purchase requires an irrevocable liability to take and pay for the share. Otherwise, logical consistency would dictate that a share sale requires an irrevocable liability to sell the share. The purchase of a put clearly does not meet this implicit Ogsbury standard of what constitutes a "sale." Thus the Ogsbury doctrine permits a "profitfreezing" transaction that is a clear evasion of section 16(b).221

c. SEC rulemaking. In its new comprehensive framework for derivative securities, the SEC ended its silence on put options and adopted a set of rules that would clearly include hypothetical C3

220. In commenting on a scenario essentially identical to hypothetical $\mathrm{C} 3$, the SEC stated that prior to the new rules "it is questionable whether the courts would have found liability." Implementing Release, supra note 205 , at $81,261 \mathrm{n} .114$. The reason for its skepticism was that with certain exceptions "the courts have been reluctant to match transactions in two different types of securities." Id.

221. A number of commentators writing prior to the 1991 rule revisions suggested that it would be desirable for $\S 16$ (b) to cover such transactions, but, because of an unwillingness to confront the Ogsbury doctrine, either concluded that it does not or suggested confusing reasons why it does. One commentator argued, all within the same article, that (i) a purchase and sale of a call or put is covered by $\S 16(\mathrm{~b})$ because the call or put itself is an "equity security of such issuer," Exchange Act $\S 16(\mathrm{~b}), 15$ U.S.C. $\S 78 \mathrm{p}(\mathrm{b})(1988)$; (ii) a purchase of a put is instead a sale of the underlying share when it is preceded within six months by the purchase of a share; and (iii) the exercise of a put rather than its purchase is the sale of the underlying security when the exercise is followed by the purchase of a share within six months. Note, supra note 134 , at $872-74,883-85,876-77$. Another concluded that $\S 16$ (b) does not apply to a share purchase followed less than six months later by a put purchase that is exercised more than six months after the put purchase, but $\S 16(\mathrm{~b})$ does cover a share purchase followed more than six months later by a put purchase that is exercised less than six months after its purchase. Beatty, supra note 134 , at 528 \& n.59. This conclusion appears to be based on the idea that the put purchase cannot be matched against the share purchase because under the Ogsbury doctrine the put purchase is not a share sale, but that the share sale at exercise can be matched against the put purchase because one transaction is a purchase of some sort and the other a sale of some sort. Id. 
within the reach of section 16(b). The SEC defines a "put equivalent position" to be "a derivative security position that increases in value as the value of the underlying equity decreases," and it includes in this definition the holding of a put option. ${ }^{222}$ Another rule deems "the establishment of or increase in a put equivalent position" to be a statutory "sale" of the underlying security. ${ }^{223}$ Thus, $U$ 's purchase of 500 puts in March can be matched as a "sale" against his purchase of 500 shares two months earlier.

The SEC's new rules clearly reach the correct result, but again this apparent expansion of the reach of section 16(b) through definitional rulemaking would be more likely to survive court challenge if the reasons for the rules were better articulated. The main justification provided by the SEC for including the purchase and excluding the exercise of call options - that they represent indirect ownership of the underlying securities ${ }^{224}$ - does not really work for put options. Nor is it correct to say, as it is in justifying the inclusion of call options, that $U$ 's February puts purchase should be matched with the January share purchase because the puts purchase, as a transaction that "provide[s] an opportunity to obtain or dispose of the stock at a fixed price," occurs when "the opportunity to profit commences." 225 In our example, that opportunity would arise in January.

For the rationale treating a put purchase as a sale in this context to be persuasive, it must address the function of the six-month cutoff; it is the fact that the put purchase follows so soon after the share purchase that raises the issue of whether section 16(b) should apply in the first place. The closest the SEC comes to providing such a rationale is in its discussion of an example closely resembling hypothetical C3. The SEC says that with a put purchase that follows a share purchase within six months, "the insider lock[s] in the ability to earn a profit." 226 For this point to be persuasive it needs to be fleshed out in the manner set out above. Because of its effect

222. Rule 16a-1(h), 17 C.F.R. § 240.16a-1(h) (1993).

223. Rule 16b-6(a), 17 C.F.R. $\$ 240.16 b-6(a)$ (1993). The rule also provides that "a decrease in a put equivalent position shall be deemed a purchase." Id. Thus, under the new rules, $\S 16(\mathrm{~b})$ would cover a situation in which $Z$ on January 1 purchases 1000 nine-month ABC puts for $\$ 4$ each with an exercise price equal to the current market price of $\$ 50$ and on February 1 , when the market price has fallen to $\$ 40$, sells the puts for $\$ 13$ each; this would be the mirror image of hypothetical $\mathrm{C} 2$, in a declining instead of increasing market. The put purchase, which would be a "sale," is followed within six months by the put sale, which would be a "purchase."

224. See supra note 198 and accompanying text.

225. Implementing Release, supra note 205 , at 81,258 .

226. Id. at 81,260 . 
on the risk characteristics of portfolio cash flows, a put purchase is the near equivalent of a share sale. A put is almost as effective as a sale in reversing the extra risk of portfolio dediversification that results from the purchase of shares based on positive inside information. Treating put purchases as sales would deter insiders from such share purchases by telling them that if they do make such purchases they must live with the resulting dediversification for at least six months in order to avoid giving up their profits.

\section{Stock-Price-Based Officer and Director Compensation Plans - Employee Stock Options and Stock Appreciation Rights}

Consider hypotheticals D1 and D2. In D1, $Z$ has been an officer of $A B C$ for several years. $Z$ is still an officer on January 1,1987 , when $A B C$ grants him nontransferable employee stock options for $100 \mathrm{ABC}$ shares exercisable at the current market price of $\$ 20$. The options are exercisable starting one year after the date of grant and expire five years after the date of grant. $Z$ exercises his ESOs on March 1, 1990, when the shares are trading at $\$ 60$. He sells the 100 shares acquired with the options on the same day. Should some or all of $Z$ 's $\$ 4,000$ profit be recoverable by $\mathrm{ABC}$, given that the exercise was followed within six months by a sale? The class of paired transactions at issue here are director and officer exercises of nontransferable ESOs that were granted more than six months earlier, followed within six months of exercise by a sale of the shares so purchased.

In hypothetical $\mathrm{D} 2, \mathrm{ABC}$ grants $Z 100$ stock appreciation rights (SARs) on January 1,1987 . The SARs entitle $Z$ to receive in cash the difference between the exercise price, in this case again the current market share price of $\$ 20$, and the market share price on the date of exercise. Just like the options in D1, these SARs are exercisable starting one year after the date of grant and expire five years after the date of grant. $Z$ exercises his SARs on March 1, 1990, when the shares are trading at $\$ 60$, and receives $\$ 4,000$ in cash from ABC. Should some or all of $Z$ 's $\$ 4,000$ profit be recoverable by ABC under a theory that the exercise of the SARs is, in economic terms, identical to hypothetical D1 (an exercise of a stock option followed by the immediate sale of the shares)? In other words, should section 16(b) apply? 


\section{Application of the Rule of Decision}

a. Employee stock options. The exercise of the ESOs in hypothetical D1 cannot in and of itself be a purchase of shares motivated by inside information. A purchase is only motivated by inside information if the purchaser relies on positive, nonpublic information to acquire shares at a price that is lower than it will be when the information is made public. Here, the purchase price is fixed under the ESO and it will remain the same regardless of whether the information that $X$ knows becomes public. The exercise is, however, a precondition to the sale of the underlying shares and the sale can be motivated by inside information. Because the only kind of information that motivates sales is negative information, we can analyze the problem with the model of a world in which there is only negative information.

The fact that a director or officer would, in the absence of the statute, sell shares less than six months after he acquires them through the exercise of an ESO tells us nothing about whether or not the sale is motivated by inside information. Regardless of the motivation for the sale, the officer has no reason to exercise the option until he intends to sell the underlying shares. If an officer postpones the exercise of the ESO until the moment of sale instead of exercising the ESO and holding the shares, he can enjoy any increase in share price that occurs without tying up capital or taking a risk that the market price will drop below the exercise price.

Because the fact that shares are held for less than six months after the exercise of the ESO is useless as the basis of a rule of inference, the principle of decision suggests that this class of paired transactions should not be included under section 16(b). Among the potential universe of transactions involving the sale of shares acquired pursuant to ESOs, inclusion of this particular class of transactions under section 16(b) would burden as high a proportion - $100 \%$ - of potential sales not based on inside information as potential sales based on inside information. Moreover, there is no reason to think that a larger proportion of potential sales of ESOacquired shares would be based on inside information than of potential sales of shares acquired by officers and directors through ordinary market purchases. ${ }^{227}$

227. Although the class of potential sales of shares acquired within the prior six months pursuant to employee stock options does not contain a larger proportion of sales based on inside information than director and officer sales generally, it might be argued that this class of transactions should nevertheless be included under $\S 16(\mathrm{~b})$ because its inclusion would be particularly effective at deterring insider sales. Assume for a moment that directors and officers, in order to retain for as long as possible the advantages of being option holders 
It is important to note that this discussion addresses only the pairing of the share sale with the exercise of the ESO. The share sale, however, has the same portfolio effect as any ordinary share sale and should be matched with any ordinary share purchase occurring within six months.

b. Stock appreciation rights. Z's exercise of the SARs in hypothetical D2 is, in economic terms, identical to his exercise of the ESOs and immediate sale of underlying shares in D1. The rule of decision would again suggest, therefore, that the SAR exercise, standing by itself, should not give rise to section 16(b) liability. The SAR exercise has the same portfolio effect as an ordinary sale of shares and as such it should be matched against any ordinary purchase occurring within six months. ${ }^{228}$

\section{Court Decisions and Pre-1991 SEC Rulemaking}

a. Employee stock options. Before 1991, the law concerning the treatment of ESOs was the unsatisfactory culmination of a complex course of development. The courts and the SEC addressing the treatment of ESOs confronted the same basic questions that we en-

rather than shareholders, do not exercise their options until the desire to sell arises. The effect of imposing $\S 16(\mathrm{~b})$ is to delay the sale for six months after his desire arises because, to avoid the penalty of the statute, he must exercise the option and wait the period. For potential sales based on inside information, the information will almost certainly become public during the six months waiting period and the officer and director will have lost his advantage. Thus, inclusion of this class of transactions under $\S 16(\mathrm{~b})$ should almost completely eliminate such sales.

The effectiveness of the inclusion of this class of paired transactions is the result of singling out sales of shares acquired pursuant to employee stock options for particularly onerous treatment. If we were to treat sales of shares acquired by ordinary market purchases in an equivalent fashion, we would have to require directors and officers to commit to the sales six months in advance. Such a rule would almost completely eliminate sales of such shares based on inside information. Congress did not choose to impose such a requirement on the sales of shares acquired by ordinary market purchases, presumably because it would impose too great a burden on managerial shareownership. There is no good justification, therefore, for imposing a similar requirement on the sales of shares acquired pursuant to employee stock options.

Both the argument and the response are premised on the assumption that the option holder will not exercise his option prior to the moment that his desire to sell arises. If $\S 16(b)$ were imposed on this class of transactions, however, directors and officers may exercise their options prior to that moment in order to create more flexibility in the timing of their sales. This would be true both of officers and directors whose sales are ultimately based on inside information and of those whose sales are not so based. If directors and officers do behave this way, the argument for imposing $\S 16(\mathrm{~b})$ is no stronger. The direct burden imposed by the statute on potential sales not based on inside information is less, but so is the effectiveness of the statute in deterring potential sales based on inside information. Moreover, in the process the statute would cause directors and officers to behave in a way that undermines the special agency-cost-reducing features of compensation through employee stock options by making such compensation relatively less attractive than paying a straight salary.

228. The economic equivalence of the SAR exercise to the ESO exercise and immediate share sale indicates that the appropriate sale price for calculating the amount of profits, if any, derived from such a matched purchase and sale would be the market price on the date of the exercise. 
countered with market-purchased options: Is the acquisition of an ESO a "purchase" of an "equity security of the issuer?" 229 Is the exercise of the ESO, because it disposes of the option, a "sale" of an equity security? Finally, regardless of the answer to this second question, is the exercise of the option, because it results in the acquisition of a share, a "purchase" of an equity security?

$i$. Acquisition of the ESO. As with market-acquired options, there are two potential approaches for establishing that an officer's or director's receipt of an ESO pursuant to a grant by his employer should be considered a "purchase" of "an equity security of such issuer" 230 under section 16(b). The first approach holds that the acquisition of an ESO should be considered a purchase of the underlying shares. This approach has met with uniform judicial resistance. All the ESO cases follow the Ogsbury approach and hold that the underlying shares are not purchased until the employee incurs "an irrevocable liability to take and pay for the stock." 231 For ESOs, the irrevocable liability arises not at the time of the option's acquisition but later at the time of its exercise. ${ }^{232}$ The second approach holds that the ESO itself is an "equity security of [the] issuer."233 This approach avoids the Ogsbury doctrine and seems to be unassailable. An ESO is clearly an equity security because it is an option and because Congress has amended the definition of "equity security" to include stock options. ${ }^{234}$ Moreover, because it is written and granted by the issuer, an ESO should fit within even the narrowest reading of the phrase "of such issuer."235 Because ESOs are generally nontransferable, however, there will never be any "sale" to match against the "purchase" under this second approach unless exercise of the ESO is deemed to be a sale.

The courts have apparently been mesmerized by the Ogsbury doctrine, and so they have missed a third, better approach to deal-

229. Exchange Act $\S 16(b), 15$ U.S.C. \& 78p(b) (1988).

230. Exchange Act $\S 16(\mathrm{~b}), 15$ U.S.C. $\S 78 \mathrm{p}(\mathrm{b})(1988)$.

231. Blau v. Ogsbury, 210 F.2d 426, 427 (2d Cir. 1954); see also supra notes $142-43$ and accompanying text.

232. See, e.g., Arrow Distrib. Corp. v. Baumgartner, 783 F.2d 1274, 1276-77 (5th Cir. 1986) (holding the purchase date to be the date the ESO was exercised); Riseman v. Orion Research, Inc. 749 F.2d 915, 920 (1st Cir. 1984) (same); Matas v. Siess, 467 F. Supp. 217, 224 (S.D.N.Y 1979) (same); see also JENNINGS ET AL., supra note 12, at 1392, 1401.

233. Exchange Act § 16(b), 15 U.S.C. \& 78p(b) (1988).

234. See supra note 147 and accompanying text.

235. See supra notes $147-50$ and accompanying text. Long before the 1991 rules, the SEC accepted ESOs as satisfying the Exchange Act's definition of an "equity security of such issuer." Interpretive Release on Rules Applicable to Insider Reporting and Trading, Exchange Act Release No. 18,114, 4 Fed. Sec. L. Rep. (CCH) I 26,062, at 19,063-29 to -31 (Sept. 23, 1981). 
ing with the acquisitions of most ESOs. This approach, which flows naturally from the model in Part II, would greatly simplify the treatment of ESOs under section 16(b). The acquisition of an ESO should, like any other option, be considered an acquisition of the underlying shares. Unlike a market-acquired option, however, an ESO acquisition should not generally be considered a section 16(b) "purchase." An ESO acquisition is an "unorthodox," not a traditional "cash for stock," transaction, and thus it should be analyzed by the Kern County "pragmatic" test. 236 The pragmatic test asks "whether the transaction may serve as a vehicle for ... the realization of short-swing profits based upon access to inside information."237 The typical acquisition of an ESO does not serve as such a vehicle. The grant occurs either because of the actions of others or pursuant to the automatic operation of some formula established by the corporation, probably not in the preceding six months. The insider takes no action at the time that she receives the ESO. The acquisition therefore cannot be the result of the insider's knowledge of any nonpublic information. Nor could it reflect an insider's decision to engage in a dediversifying reversal of an earlier sale based on negative inside information.

ii. Disposition of the option at exercise. As with call options acquired by purchase or contract, there are no reported cases holding that the exercise of an ESO is a simultaneous "sale" of the option and "purchase" of the underlying shares. ${ }^{238}$

iii. Acquisition of the share at exercise. All the cases that have considered the issue have treated a share acquisition resulting from the exercise of an ESO as a section 16(b) "purchase." There is, however, a long and somewhat convoluted history of SEC rulemaking exempting at least some such exercises from section 16(b). In 1935 , the SEC adopted former rule 16b-3,239 which in its original version exempted from section 16(b) coverage the exercise of ESOs, provided that the plan satisfied certain provisions. ${ }^{240}$ At that

236. Kern County Land Co. v. Occidental Petroleum Corp., 411 U.S. 582, 593-95 (1973). The Court gives "dealings in options" as an example of an "unorthodox" transaction. 411 U.S. at 593 n.24. See supra note 166.

237. Kern County, 411 U.S. at 594.

238. See supra note 162 and accompanying text.

239. 17 C.F.R. § 240.16b-3 (1949).

240. The exercise of ESOs was exempt from $\S 16(\mathrm{~b})$ coverage, provided that (i) the purchase was pursuant to a nontransferable option granted prior to or on June 6,1934 , in connection with an employment contract; (ii) the sale was made subsequent to October 9 , 1935; (iii) the plan was approved at a shareholders' meeting; and (iv) the price of the stock under the option was higher than the market price of the stock at the time the option was granted. 17 C.F.R. § 240.16 b-3 (1949). 
time, the SEC simply stated that it found that these transactions were "not within the purpose of section 16(b)" without giving any reason. ${ }^{241}$ Because one of the provisions governing the application of the original rule $16 \mathrm{~b}-3$ required that the grant had to have been made prior to June 6,1934 , the 1935 rule became increasingly obsolete and in 1949 the SEC amended it. ${ }^{242}$ The 1949 version of rule $16 \mathrm{~b}-3 \mathrm{had}$ a very different thrust than the 1935 rule. The 1949 rule provided an exemption for the acquisition of actual stock received through bonus plans that conformed with the rule, but it specifically did not provide an exemption for transactions involving options, warrants, or other rights to purchase securities. ${ }^{243}$ The SEC gave no reasons for this switch. ${ }^{244}$ The SEC again amended rule 16b-3 in 1952 to exempt the acquisition of ESOs and, it would appear as well, the acquisition of stock pursuant to the exercise of ESOs. ${ }^{245}$ In 1956, the SEC further amended rule 16b-3246 to "make[ ] it clear that the exemption applies to the acquisition of stock [the exercise] pursuant to non-transferable options." 247

This exemption for stock acquired pursuant to the exercise of ESOs did not fair well in the courts. In Greene v. Dietz, ${ }^{248}$ the Second Circuit stated "we express doubt as to the power of the Commission to promulgate Rule X-16B-3 inasmuch as the Rule's broad language may permit acts by insiders sought to be prevented by the Securities Exchange Act." ${ }^{249}$ Soon after, in Perlman $v$.

241. Exchange Act Release No. 392 (Oct. 9, 1935).

242. Exchange Act Release No. 4253, 14 Fed. Reg. 2522 (May 5, 1949).

243. Id. The rule stated, in pertinent part, "Any purchase of an equity security (other than a convertible security or a warrant or right to purchase a security) by a director or officer of the issuer of such security shall be exempt from the operation of section 16(b)." Id. at 2522-23 (emphasis added).

244. See id.

245. Exchange Act Release No. 4754, 17 Fed. Reg. 8900 (Sept. 24, 1952). The rule stated, in pertinent part, "Any acquisition of shares of stock or nontransferable options (other than convertible stock or stock acquired pursuant to a transferable option, warrant or right) by a director or officer of the issuer of such stock shall be exempt from the operation of section 16(b)." Id. (emphasis added).

Rule 16b-3 was amended once between May 6, 1949, and September 24, 1952, but this amendment did not affect ESOs. Exchange Act Release No. 4584, 16 Fed. Reg. 2679 (Mar. 19, 1951).

246. Exchange Act Release No. 5312, 21 Fed. Reg. 3646 (May 18, 1956). The rule stated, in pertinent part, "Any acquisition of non-transferable options or of shares of stock including stock acquired pursuant to such options by a director or officer of the issuer of such stock shall be exempt from the operation of section 16(b)." 21 Fed. Reg. at 3647 (emphasis added).

247. Id. at 3646 .

248. 247 F.2d 689 (2d Cir. 1957).

249. 247 F.2d at 692 . The trial court dismissed the plaintiff's complaint after trial. The trial court expressly held that the 1952 promulgation of rule $16 \mathrm{~b}-3$ was within the power of the Commission. The Second Circuit found it unnecessary to adopt this portion of the trial court's opinion in order to affirm its dismissal of the complaint because the defendants had 


\section{Timberlake, ${ }^{250}$ the U.S. District Court for the Southern District of New York held rule $16 \mathrm{~b}-3$ to be invalid. ${ }^{251}$ Explicitly reacting to these two decisions, the SEC amended rule $16 \mathrm{~b}-3$ in 1960 to elimi- nate the exemption for exercising ESOs. ${ }^{252}$ Thus, rule $16 \mathrm{~b}-3$ was reduced to providing exemptions only for the grant, as opposed to the exercise, of ESOs and bonus plan shares, subject in each case to}

relied in good faith on the rule and thus were entitled to the protection from liability provided by § 23(a) of the Exchange Act. 247 F.2d at 690-94; see supra note 116.

The SEC filed a petition, as amicus curiae, for a rehearing, asking for a clarification concerning the court's beliefs as to the validity of the rule. The court in a per curiam opinion responded as follows:

The petition and brief demonstrate that the Securities Exchange Commission understands, without further clarification, the content of our opinion. We learn therefrom that it is re-evaluating its Rule X-16B-3. In the meantime, pending any [such] modification ... it would seem that any reliance upon it by persons entitled to exercise stock purchase options under employee stock option plans . . . would be ill-advised.

Id. at 697 (emphasis added).

250. 172 F. Supp. 246 (S.D.N.Y. 1959).

251. The court stated, "We hold that Rule X-16b-3 is in conflict with the express purpose of the statute and therefore invalid." 172 F. Supp. at 258 . Despite its finding of invalidity, the court granted the defendants' motion for summary judgment, on the grounds, as in Greene, that their good faith reliance on the rule protected them from liability pursuant to $\S 23(\mathrm{a})$ of the Exchange Act. $172 \mathrm{~F}$. Supp. at 258.

The court in Timberlake observed that the structure of the Second Circuit's opinion in Greene "logically and rhetorically presupposes a prior determination of invalidity" and that "the logical effect of [its] expression of doubt ... is that of a holding." $172 \mathrm{~F}$. Supp. at 253 . It suggested that the reason the Second Circuit "refrained from an unequivocal declaration of invalidity" was "to give the Commission an opportunity to bring the rule in line with Congressional intent - as disclosed by the per curiam opinion on the rehearing." $172 \mathrm{~F}$. Supp. at 253; see supra note 249. But see Continental Oil Co. v. Perlitz, 176 F. Supp. 219, $226-27$ (S.D. Tex. 1959) (holding that the SEC does possess the power to promulgate rule 16b-3 because the SEC provided adequate and reasonable reasons for the rule).

252. Exchange Act Release No. 6275, 25 Fed. Reg. 4901 (May 26, 1960). The newly revised rule stated, in pertinent part, "Any acquisition of shares of stock (other than stock acquired upon the exercise of an option, warrant or right) ... shall be exempt from the operation of section 16(b)." Id. at 4902 (emphasis added).

In the release announcing the proposed rule change, the Commission took note of Greene and Timberlake and cited a report by its staff recommending deletion of the ESO exercise exemption. It said that this recommendation was based on a review of these court decisions and "the possibilities of abuse arising out of the rule." Exchange Act Release No. 6111, 24 Fed. Reg. 9272 (Nov. 5, 1959). The closest that the staff report came to identifying any abuses that came from the ESO exercise exemption was the following statement:

In recommending the [ESO exemption deletion] be deleted, we have concluded that Rule $16 \mathrm{~b}-6$ provides a means for separating profits which may be attributed to long term increments in value arising from the very nature of the restricted stock option device, and which the statute is not designed to discourage, from the profits fairly attributable to the short term aspects of the transaction which the Act intended to denude of profit.

$I d$. at 9273 . Former rule $16 \mathrm{~b}-6$ measured the profit inuring to the issuer from a sale within six months after exercise of an option to be the difference between the sale price and the lowest market price in the period extending from six months before the date of sale to six months after the date of sale. 17 C.F.R. $\$ 240.16 \mathrm{~b}-6$ (b) (1990) (amended 1991). The rule appeared to express the concerns that the insider either postponed the sale knowing that good news would come out soon or accelerated the sale knowing that bad news would come out soon both inappropriate concerns for $\S 16$ (b) because they are equally applicable to sales of shares that have been held a long time. 
an increasingly complex set of qualifications relating to shareholder approval and administration of the plan. ${ }^{253}$

b. Stock appreciation rights. Exercising an SAR, as we have seen, is the economic equivalent of exercising an ESO and immediately selling the underlying shares. Both transactions, therefore, present the identical range of opportunities for abuse of inside information. Contrary to the approach advocated here, the courts have uniformly held that the share acquisition resulting from the exercise of an ESO is a section 16(b) "purchase" that can be matched with a sale of the shares obtained. ${ }^{254}$ Judicial consistency would require courts to treat an SAR exercise as a section 16(b) purchase and sale as well. Indeed, the one court that has faced the issue reached just that conclusion and thus in hypothetical D2 would have permitted $\mathrm{ABC}$ to recover profits from Z.255 There are, however, cases concerning the exercise of SARs in which the courts focused on other aspects of the particular complex transactions involved and in the end did not find section 16(b) applicable. ${ }^{256}$

In 1976 the SEC recognized that if section 16(b) were applied to all SAR exercises, SARs would "essentially be worthless as a means of executive compensation." 257 As a result, the SEC ultimately adopted former rule $16 \mathrm{~b}-3(\mathrm{e}),{ }^{258}$ which exempted the exercise of most cash-settlement SARs held for more than six months from section 16(b) liability. This exemption only applied, however, if the exercise of the SAR occured within a ten-day window following the issuer's announcement of quarterly sales and earnings. ${ }^{259}$ Under this rule, $Z$ 's profits in D2 would not be subject to disgorgement under section 16(b) if the date of exercise, March 1, were within

253. Rule 16b-3, 17 C.F.R. \& 240.16b-3 (1961).

254. See supra note 232.

255. Matas v. Siess, 467 F. Supp. 217, 224 (S.D.N.Y. 1979).

256. Freedman v. Barrow, 427 F. Supp. 1129, 1151-52 (S.D.N.Y. 1976) (holding that the exercise of an SAR accompanied by the surrender of a stock option did not constitute a purchase and sale of the underlying security as long as the transaction constituted "an election between two methods of previously granted executive compensation" in a regime that gave the executive a choice of an SAR or an option); Rosen v. Drisler, 421 F. Supp. 1282, 1287-88 (S.D.N.Y. 1976) (holding that repurchases of options granted to executives for the difference between the option exercise price and the market price were not equivalent to SARs because the transactions "presented no opportunity for speculation").

Professors Loss and Seligman criticize these cases as "elevat[ing] form over substance" given the cases holding that an exercise of an option and sale of the shares is subject to $\$ 16$ (b) liability. 5 Louis Loss \& Joel Seligman, Securities Regulation 2362 (3d ed. 1990).

257. Exchange Act Release No. 13,097, [1976-1977 Transfer Binder] Fed. Sec. L. Rep. (CCH) If 80,835, at 87,202 (Dec. 27, 1976).

258. 17 C.F.R. \& 240.16b-3(e) (1977) (amended 1991).

259. 17 C.F.R. $\$ 240.16 b-3(e)(3)(i i)(1977)$. 
that window. Otherwise, the profit could be recovered by $A B C$ under section 16(b). Providing an exemption for the imputed purchase portion of the SAR exercise, while inconsistent with the SEC's earlier decision not to exempt the exercise of ESOs, is obviously consonant with the approach advocated here. Restricting the exemption to a quarterly ten-day window is not consistent with the approach we advocate, but this feature unfortunately has been retained under the 1991 wholesale SEC revisions discussed in more detail below. ${ }^{260}$

The SEC, in originally proposing former rule $16 \mathrm{~b}-3(\mathrm{e})$, stated that it could delineate situations in which the exercise of SARs would not present an opportunity for the unfair use of inside information, ${ }^{261}$ and in its release adopting the final version of the rule, the SEC stated that providing the window period was the most effective means of identifying those situations. ${ }^{262}$ The SEC presumably reasoned that this period is the one in which it is least likely that the person exercising the SAR possesses information not reflected in the market price. But, as we saw in the discussion applying the rule of decision to hypotheticals D1 and D2, the fact that an insider possesses inside information at the time of exercise is irrelevant to a consideration of the ways in which a short-swing rule can deter those transactions that are particularly likely to be based on inside information. Regardless of the length of time the SAR has been held or the role the insider has played in obtaining it, the only nonpublic information that would prompt an insider to exercise an SAR is negative information, and that information only promotes the "sale" that is imputed in the exercise of an SAR. There is no more reason to impose liability on SAR exercises standing by themselves just because they are made outside the window period than to impose liability on sales, made outside this window period, of shares that have been held for many years. Conversely, there is no more reason to exempt the sale aspect of a window-period exercise of an SAR that has been held more than six months from being matched against any ordinary purchase occurring within six months before or after than there is reason to exempt an ordinary share sale made within that window period from such a matching. ${ }^{263}$

260. See infra section III.D.3.

261. Exchange Act Release No. 12,374, [1975-1976 Transfer Binder] Fed. Sec. L. Rep. (CCH) \ 80,462, at 86,205 (Apr. 23, 1976).

262. Exchange Act Release No. 13,659, 4 Fed. Sec. L. Rep. (CCH) I 26,085, at 19,091 (June 22, 1977).

263. Stating the proposition in this way reveals the futility of trying to isolate periods in which insiders are unlikely to possess material nonpublic information. It is doubtful that the 


\section{The 1991 Rule Revisions}

In 1991, the SEC undertook wholesale revisions of the section 16 rules and changed the treatment of ESOs and SARs. Under the 1991 revisions, the treatment of ESOs and SARs is largely built around the concept that ESO and SAR ownership constitutes indirect ownership of the underlying equity securities, the same concept already discussed in connection with market-acquired options.

The new scheme is a large step forward, but again the SEC has left several problems by failing to articulate a fully coherent theory for the application of section 16(b). To start, the new ESO and SAR regime still contains a highly complex set of restrictions mostly historical relics from the prior regime - that a betterarticulated theory of section $16(\mathrm{~b})$ would reveal to be needless and thus wasteful of both private legal resources and SEC staff time. Former rule $16 \mathrm{~b}-3$, the heart of the earlier regime and the source of these historical relics, prompted more interpretative requests than any single other SEC rule. ${ }^{264}$ New rule 16b-3 appears to continue in this tradition. Because of these interpretative problems, the SEC is considering further rulemaking. The effective date of new rule $16 \mathrm{~b}-3$ has been postponed twice, and the rule now is not scheduled to become effective until September 1, 1994, which is more than three years after its adoption. ${ }^{265}$ Also, the unnecessary restrictions

SEC thinks that it has been so successful at identifying such periods with its window periods that it would want to extend the exemption to ordinary sales. Many events that move share prices significantly are announced at times other than quarterly earnings announcements; for example, new inventions, new contracts, changes of chief executive, merger talks, and dividend changes.

264. Peter J. Romeo \& Alan L. Dye, Reforming Section 16, 22 Rev. Sec. \& CommodiTIES REG. 23, 27 (1989).

265. Implementing Release, supra note 205 , at 84,709 (providing a 16-month phase-in period, until Sept. 1, 1992); Exchange Act Release No. 30,850, [1992 Transfer Binder] Fed. Sec. L. Rep. (CCH) II 85,004, at 82,888 (June 23, 1992) (extending the phase-in period until Sept. 1, 1993, and stating that "the Commission intends to engage in further rulemaking in order to streamline the reporting requirements and exemptions applicable to employee benefit plan transactions"); Exchange Act Release No. 32,574, [1993 Transfer Binder] Fed. Sec. L. Rep. (CCH) II 85,206, at 84,235 (July 2, 1993) (stating that "further Section 16 rulemaking remains under consideration" and extending the phase-in period until Sept. 1, 1994, or an earlier date as set in such rulemaking).

The interpretative questions raised by the new rules appear to be posing a significant burden for the SEC staff. The Division of Corporation Finance announced in response to two "no-action" letter requests concerning new rule 16b-3 that it would no longer repeat answers to questions relating to $\S 16(\mathrm{~b})$ if it regarded the issue as having been raised before and answered in previous publicly available no-action letters or SEC releases. Dial Corp., SEC No-Action Letter, [1991-1992 Transfer Binder] Fed. Sec. L. Rep. (CCH) I 76,143, at 79,837 (Apr. 14, 1992); Pinnacle West Capital Corp., SEC No-Action Letter, [1991-1992 Transfer Binder] Fed. Sec. L. Rep. (CCH) I 76,138, at 79,355 (Mar. 25, 1992). This decision runs contrary to the traditional SEC policy that companies should not rely on no-action letters addressed to others. See, e.g., Securities Act Release No. 5073, [1969-1970 Transfer Binder] Fed. Sec. L. Rep. (CCH) $\mathbb{I} 77,838$, at 83,980 (July 14, 1970) (“[N]o-action and inter- 
on ESOs and SARs reduce, for no good reason, the attractiveness of these agency-cost-reducing forms of executive compensation. At the same time, hidden behind the new regime's complexity are some surprising gaps that permit insider trading where application of short-swing based liability would help prevent it. A betterarticulated theory would have revealed these gaps. Finally, the lack of a coherent theory exposes the progress that has been achieved to the unnecessary risk of judicial invalidation.

a. Employee stock options. New rule 16b-6 clearly indicates that the exercise of any "in the money" option, whether or not it is an ESO, is not a "purchase." The special issue for ESOs, therefore, is the status of the original grant of the option. New rule 16b-3266 also exempts this grant from being a "purchase" if certain conditions are met. First, the grant must be made pursuant to a written plan that specifies the terms of the ESO and the eligibility requirements for participation. Additionally, the determination of the recipient, quantity, and date of the award of ESOs must be made either by a formula or by a committee of disinterested directors. Moreover, the plan and any material amendments thereto must be approved by the shareholders. Furthermore, there is a minimum six-month holding period between the date of the grant and the date of disposition of the ESO or its underlying security. Finally, the ESOs must be nontransferable. ${ }^{267}$ The provisions requiring a written plan and the use of certain methods for determining the recipient, amount, and timing of ESO grants are necessary and appropriate requirements for exempting such grants. These requirements go to what should be the essential question in determining the availability of the exemption: whether the receipt of the ESO and its timing are within the control of the recipient. When an insider has some degree of control over the receipt, the receipt involves an element of volition that, paired with a share sale within six months before or after, suggests a heightened probability that nonpublic information motivated one of the transactions. Without insider control, the receipt of the ESO suggests nothing about the possibility that inside information has been abused: the receipt can neither itself be triggered by the insider's possession of positive

pretative responses by the staff are subject to reconsideration and should not be regarded as precedents binding on the commission.").

266. 17 C.F.R. § 240.16b-3 (1993).

267. Exceptions are allowed for death, retirement, disability, end of employment, and qualified domestic relations orders. 17 C.F.R. $\S 240.16 b-3(d)(2)(i)(B)(1993)$. 
nonpublic information nor represent a postdisclosure reversal of an earlier sale based on nonpublic negative information.

None of the other requirements for an ESO grant exemption, however, fits appropriately into a short-swing-based scheme for deterring insider trading. At best, they appear to be misconceived "suspenders" in a "belt and suspenders" approach to preventing ESO grants from being vehicles for the abuse of inside information. First, consider shareholder approval. If in fact a plan's recipients have no control over the grant of ESOs, shareholder approval is irrelevant. If a plan does permit some control, the chances are slim that an abusive grant of an ESO could slip by the SEC provisions expertly designed to screen out plans permitting control but still be caught by the shareholders. ${ }^{268}$ The approval requirement not only is ineffective but it also has significant costs. The cumbersome process of seeking shareholder approval of any "material" change chills plan innovation and limits plan adaptability as circumstances

268. Individual shareholders in public companies normally vote the way management recommends. They suffer from the usual collective action problem of having little incentive to inform themselves extensively because of the small chance that their vote will make the difference. See Black, supra note 22, at 560 (deeming collective action problems an "important" cause of shareholder passivity). It might be argued that the real way that the shareholder requirement could stop plans permitting some control would be the same way that many disclosure requirements promote good corporate governance: managers would not want to make the disclosures that seeking shareholder approval of such plans would entail. This argument is not persuasive. Even if public issuers were not required to seek shareholder approval for ESO plans and their amendments to qualify for the $\$ 16(\mathrm{~b})$ grant exemption, they would still have to provide, annually, detailed disclosure concerning such compensation arrangements. 17 C.F.R. \& 229.402 (1993) (providing the requirements for disclosure of executive compensation).

In the period leading up to the 1991 wholesale revision of the rules, the SEC initially proposed to eliminate the shareholder approval requirement that had been part of old rule 16b-3. The SEC stated that the requirement "has been viewed as a measure that deters insiders from implementing compensation plans that allow for abuse of inside information" but that it "has been criticized as unclear, burdensome, and ineffective as a deterrent." It proposed instead "greater reliance on the disinterested administration requirement to assure that opportunities for abuse are minimized." Initial Release, supra note 7, at 89,618.

The SEC justified its decision to reverse this initial proposal and to retain the requirement by noting that "concerned shareholders, commenting on the proposals, urged that shareholders have an interest in not only the level of compensation, but that compensation be designed to enhance the longer term horizon of management." Implementing Release, supra note 205, at 81,268 . Thus the ESO grant exemption is being provided subject to a condition that, according to this justification, is totally unrelated to $\S 16(\mathrm{~b})$ 's statutory purpose of deterring the unfair use of inside information.

Restricting an exemption for purposes unrelated to the purpose of the statute that gave the agency the power to make the exemption, while not an uncommon SEC practice, raises questions about abuse of discretion. This is particularly true when the restriction is to an exemption for which, as here, the need for the transaction in question to meet other conditions already assures that the transaction does no damage to the statutory scheme. This is to be contrasted with a restriction to an exemption for which the agency judges that the transactions permitted by the exemption will do damage to the statutory scheme but that, if the exemption is properly restricted, this damage is outweighed by the benefits the transactions will create in terms of other areas of concern to the securities laws. 
change over time. ${ }^{269}$ Furthermore, because of the inevitably vague standards governing what constitutes a "material" change, the need for frequent determinations of this sort needlessly consumes considerable legal resources and SEC staff time. ${ }^{270}$

The six-month holding period has similar problems. Again, if the recipient has no control with respect to the acquisition of an ESO, the timing of a sale relative to the acquisition date says nothing about the likelihood that inside information has been abused. If a plan that permits some control over acquisition slips through the SEC restrictions, the six-month holding period is of only very limited value in preventing abuse. For an insider with control who possesses positive nonpublic information, the holding period will provide little, if any, deterrence against his using this control to acquire an ESO. Although he must hold on to the ESO or its particular underlying security for six months to qualify for the exemption, he can reverse the portfolio effect of the ESO acquisition at any time before that point simply by selling other shares of the issuer or by purchasing puts. For an insider with control who possesses negative nonpublic information, the holding period will not deter the insider from selling shares based on the information and then, as soon as the information becomes public, using this control and acquiring ESOs to reverse the dediversifying portfolio effect of the sale. ${ }^{271}$

269. To make a material amendment, the issuer faces the choice between engaging in an expensive proxy solicitation of all the company's shareholders just for this matter and waiting until the solicitation connected with the next annual shareholders meeting, a period of as long as 12 months.

270. Initial Release, supra note 7 , at 89,618 . The shareholder approval requirement continued to create confusion after the announcement of adoption of the wholesale rule revisions in February 1991. Within three months, the SEC had to issue a detailed new release concerning what does and does not constitute a "material" change. Exchange Act Release No. 29,131, 4 Fed. Sec. L. Rep. (CCH) I 26,086A (Apr. 26, 1991). In a generally circulated memorandum to its clients, one major law firm stated that the release "substantially modifies prior interpretations of the Section 16 rules by the Commission and its Staff, and generally broadens the instances under which shareholder approval will be required" and that it "creates considerable uncertainty." Memorandum from Wachtell, Lipton, Rosen \& Katz to Clients: SEC Expands Shareholder Approval Requirement for Amendments to Employee Benefit Plans (May 10, 1991) (on file with author).

271. This analysis at a minimum shows that the six-month holding period is an unnecessary complication of the law. One might conclude, however, that it does not create a problem in terms of the other concern expressed here - making less attractive agency-costreducing executive compensation schemes. An ESO that is exercised and has its underlying shares sold all within six months has not created much incentive for the executive to increase share value. This conclusion is not completely correct. One of the things that gives an ESO value to an executive is the possibility of a merger or acquisition - something that in an era with much such activity is not a totally remote possibility within six months of a grant. The holding period would eliminate this value by creating $\$ 16(\mathrm{~b})$ liability for the exercise and sale or exercise and exchange at merger. 
The restriction on transferability will enhance an ESO's agencycost incentive structure by requiring recipients to hold ESOs for longer, ${ }^{272}$ but it is unrelated to a short-swing-based scheme to deter insider trading. Even though the ESO is not transferable, the recipient can always exercise the ESO, and there is no restriction on the transferability of the underlying shares, with the exception of the irrelevant six-month holding period.

b. Stock appreciation rights. The exercise of an SAR, it will again be remembered, is economically equivalent to the exercise of an ESO and the immediate sale of the underlying shares. Economic equivalence does not translate to equivalent legal treatment under the new rules, however. In fact they even make distinctions among SARs, setting out two separate regimes - one for SARs that pay only cash at the time of exercise and another for SARs in which there is the possibility of receiving shares equal in value to the amount of appreciation instead of cash of that value. For each kind of SAR, the exemption provided fails to cover some transactions that it should cover and covers some transactions that it should not. Also, the differential treatment between kinds of SARs is an unjustified complication.

i. Cash-only SARs. Cash-only SARs are explicitly excluded from the new rules' definition of "derivative securities" as long as they meet certain requirements. ${ }^{273}$ These requirements are the same as the ones included in rule $16 \mathrm{~b}-3$ relating to the determination of recipients and timing, shareholder approval, six-month holding period, and nontransferability. ${ }^{274}$ In making this exclusion, the SEC intended to exempt from section 16(b) liability both the grant

272. Absent a transferability exemption, it is irrational to exercise an option prior to its expiration date because it would sacrifice the continuing value of the option from the exercise date until the expiration date. If the holder wishes to cash in on her equity position prior to that date, she should sell the option instead. The buyer would then pay for that value. See supra note 155 and accompanying text. If an ESO is nontransferable, a recipient who wishes to cash in will have to sacrifice this value. The longer the recipient holds onto the ESO, the less of this value he must sacrifice. Thus nontransferability creates an incentive to hold on at least somewhat longer than would otherwise be the case.

273. Rule 16a-1(c)(3), 17 C.F.R. § 240.16a-1(c)(3) (1993).

274. Rule 16a-1(c)(3) also excludes from the definition of derivative securities cash-only SARs that do not meet these requirements but that "may be redeemed or exercised only upon a fixed date or dates at least six months after award." 17 C.F.R. § 240.16a-1(c)(3)(ii). The resulting exemption of the exercise of such an SAR seems correct because of the absence of volition in the exercise's timing. The exemption for the grant, however, is unfortunate. If the SAR's plan does not meet the rule $16 \mathrm{~b}-3$ requirements relating to the determination of recipients and timing, the recipients may have control over whether and when they receive an SAR. Use of this control to acquire an SAR presents the same opportunities as an ordinary share purchase for abuse of positive inside information and for reversal after public disclosure of an earlier sale based on negative inside information. Such an acquisition should therefore be matched against any sale within six months before or after. 
and the exercise of such cash-only SARs. ${ }^{275}$ The grant exemption is clearly correct as far as it goes, but it should go farther. It should extend to SARs granted under any plan meeting rule 16b-3's requirements concerning the determination of the recipients and timing. It should not matter whether or not the plan meets any of the other rule 16b-3 requirements, which for the reasons just discussed $^{276}$ do not appropriately fit into a short-swing based scheme for deterring insider trading.

On the other hand, the exercise exemption for cash-only SARs goes much too far. The exercise of a cash-only SAR, as long as it is volitional, is economically equivalent to a share sale. It offers the same potential for abuse of negative inside information and for the reversal, after public disclosure, of a prior purchase based on positive inside information. Thus, although an SAR exercise should not be treated as a simultaneous purchase and sale or, assuming no control at the time of grant, as a sale to be matched against the SAR's grant, the exercise should be matched against any other share purchase that occurs within six months before or after. ${ }^{277}$

ii. Other SARs. The definition of derivative securities does not exclude SARs for which the recipient may at the time of exercise receive either cash or shares equal in value to the cash. ${ }^{278}$ New rule 16b-3(c) exempts the grant of such an SAR, subject to the same requirements as are imposed for exempting a grant of an ESO and for the exclusion of a cash-only SAR. Again, for the same reasons,

\section{During the proposal process, the SEC stated:}

Under the proposed rules, many SARs that can be settled in cash only would be excluded from the definition of "derivative security" and would not be viewed as equity securities. Thus they would be exempt from Section 16. . . .

SARs would have favored treatment over options because both the "purchase" at the time of exercise of the SAR and the "sale" upon receipt of cash would be exempt, whereas a sale of stock received from an option exercise would not be exempt.

Reproposing Release, supra note 109, at 80,395 (footnotes omitted).

A court that is unsympathetic to the SEC approach could of course simply regard the excluded cash-only SARs as outside the scheme of the new rules, but, because of their economic equivalence to options, could declare them to be "equity securities" for purposes of $\S 16(b)$. It could then fashion its own rules to cover them subject to whatever extent it felt bound by the prior judicial precedent in the area. See supra notes 255-56 and accompanying text.

276. See supra notes $268-72$ and accompanying text.

277. The only rationale that the SEC gives for exempting all transactions involving cashonly SARs from $\S 16(b)$ is the statement that "[c]ash-only derivative securities that are not standardized and are awarded as part of an employee benefit plan are similar to cash bonuses, rather than equity securities." Initial Release, supra note 7, at 89,609 . This statement simply makes no sense. An SAR position, just as much as an ESO or any other call option position, increases in value as the underlying security increases in value. This correspondence in change in value between derivatives and their underlying securities is, quite properly, the whole reason behind the new rules' reformed treatment of derivative securities.

278. Rule 16a-1(c), 17 C.F.R. § 240.16a-1(c)(3) (1993). 
the requirements concerning the determination of recipients and timing are necessary and appropriate and the other requirements clearly are not.

New rule 16b-3(e) exempts the exercise of such an SAR as well if it meets a complex variety of conditions carried over from the former regime, the most important of which is the quarterly ten-day window period discussed above. ${ }^{279}$ Recall that this whole apparatus was constructed to save SARs in the face of court rulings that an option exercise is a section 16(b) purchase and that an SAR exercise is a simultaneous option exercise and sale of the underlying shares. ${ }^{280}$ The apparatus should now be abandoned. The imputed option exercise would today be exempt under the new rule $16 \mathrm{~b}-6(\mathrm{~b})$ and hence not be considered a "purchase." The only purpose served by the new rule $16 \mathrm{~b}-3(\mathrm{e})$, therefore, is to exempt the imputed simultaneous sale of the underlying shares. ${ }^{281}$ It is just as much a mistake to exempt this imputed sale as it is to exempt the sale imputed through the exercise of a cash-only SAR. In each case, the portfolio effect of the imputed sale is identical to the portfolio effect of an ordinary share sale. The imputed sale should be matched against any ordinary share purchase within six months before or after the exercise of the SAR. ${ }^{282}$

c. Viability of the new ESO and SAR rules in the face of judicial scrutiny. The new regime governing ESOs and SARs, while appropriately subject to numerous criticisms, is still a large step forward. The critical change is the recognition that ownership of an ESO or SAR is the economic equivalent to ownership of the underlying shares. This change derives from exempting, as not a "purchase," the actual or imputed acquisition of the underlying security that results from the exercise of an ESO or SAR. Remember that in

279. See 17 C.F.R. § 240.166-3(e)(3) (1993); supra notes 257-60 and accompanying text. In addition, for the exercise to be exempt, all the same requirements necessary for the grant to be exempt must be met and a disinterested administrator either must be the party determining that the consideration will be cash instead of stock or, if the recipient makes the initial choice, must approve that choice. 17 C.F.R. $\$ 240.16 b-3(e)(2)(1993)$.

280. See supra notes 255-56 and accompanying text.

281. Initial Release, supra note 7, at 89,619 ; Implementing Release, supra note 205 , at 81,272 \& n.212.

282. In the case in which the consideration for the SAR exercise is stock, the SEC incorrectly interprets new rule $16 \mathrm{~b}-6$ as exempting both the disposition of the SAR and acquisition of the shares. Implementing Release, supra note 205, at 81,272 n.209. Such an exercise is, in terms of portfolio effect, equivalent to a partial sale of shares and it should be treated as such for $\S 16(\mathrm{~b})$ purposes. Consider a modification of hypothetical D2 in which $Z$, when he exercises his 100 SARs in March 1990 , receives 66.66 ABC shares, at a share price of $\$ 60$, rather than $\$ 4,000$ in cash. This reduction in equity stake from 100 to $662 / 3$ is equivalent to a sale of $331 / 3$ shares. 
Greene v. Diet $z^{283}$ the plaintiffs challenged a previously promulgated version of just such an exemption and that the Second Circuit expressed doubt as to whether the SEC had the power to promulgate the exemption. Greene was followed by Perlman $v$. Timberlake, ${ }^{284}$ in which the court actually found the exemption to be invalid. The SEC then eliminated the exemption, acknowledging these decisions and expressing its own concern about the exemption's potential for abuse. ${ }^{285}$

Stock-price-based compensation schemes have traditionally been the frequent target of suits by members of the plaintiffs' section 16(b) bar. The new approach would eliminate many such potential suits. ${ }^{286}$ In view of Greene and the events following it, the plaintiffs' bar is almost certain to challenge the new approach in the courts. ${ }^{287}$ There are not yet any reported cases considering a direct challenge to the validity of the new rules, ${ }^{288}$ but some commentators have doubts that it can survive such a review. ${ }^{289}$ In the recent case of Frankel v. Slotkin, ${ }^{290}$ the Second Circuit refused, in light of the prior judicial precedent, to apply the new approach to events that occurred prior to promulgation of the new rules. ${ }^{291}$ This sug-

283. 247 F.2d 689, 692 (2d Cir. 1957).

284. 172 F. Supp. 246, 258 (S.D.N.Y. 1959).

285. See supra notes $248-53$ and accompanying text for a more extensive discussion of these cases and of the history of the earlier exemption.

286. One commentator stated concerning the old law, "The most usual situation leading to Section 16(b) liability, involves exercise of an employee stock option ... and the sale of those shares, at a higher price, within six months." Robert A. Barron, Control and Restricted Securities: Some Comments on Current Questions Under Section 16(b) of the Securities Exchange Act of 1934, 18 SEC. REg. L.J. 194, 195 (1990).

287. At least two commentators have expressed the possibility that the new SEC treatment of derivative securities under $\S 16$ (b) may be subjected to a court challenge by the "Section 16 plaintiffs' bar." Robert A. Barron, Control and Restricted Securities: SEC Rule 16b-6(b) - The "Relief Provision" - Permitting Section 16 Insiders To Exercise an Employee Stock Option and Sell the Stock Immediately Without Incurring Section 16(b) Liability, 19 Sec. Reg. L.J. 419, 420 (1992); Peter J. Romeo \& Alan L. Dye, The New Section 16 Regulatory Scheme, 24 Rev. Sec. \& Commodities Reg. 105, 112 (1991).

288. As discussed earlier, the rapidity of challenge is likely to be slowed by the $\S 23(\mathrm{a})$ defense of good faith reliance on SEC rules and thus must await a test case that, while not itself producing a contingency fee, will be brought to clear the way for future suits. See supra note 116.

289. Steinberg and Landsdale, noting that the new framework "directly contradicts existing judicial precedent," state that "[c]onvincing the judiciary to adopt the view that the exercise of a derivative security is an exempt transaction under section 16(b) may prove problematic." Steinberg \& Landsdale, supra note 12, at 64-65; see also Romeo \& Dye, supra note 287 , at 112 .

290. 984 F.2d 1328 (2d Cir. 1993).

291. 984 F.2d at 1338. In Frankel, the defendants were statutory insiders who had purchased on the market 1.1 million of the issuer's shares in May 1985 for $\$ 15.31$ per share (and 2500 shares for $\$ 13.71$ per share) and in July 1985 acquired puts for 3.8 million shares with an exercise price of $\$ 18$. The puts were not exercisable for at least a year. The plaintiff 
gests a possible continuing judicial sympathy to the old approach despite the new understanding that the SEC presumably hopes has come out of the process of promulgating the new rules. ${ }^{292}$

The SEC acknowledged the problems raised by the Greene and Timberlake decisions in its release promulgating the new rule. The SEC's best argument as to why its new exemption for the exercise of derivative securities should survive judicial review despite the invalidation of the old rule is its statement that "[n]ow, after 30 years of study and experience with trading in derivative securities, the Commission's rules today recognize what they did not then, that derivative securities are functionally equivalent to underlying equity securities for purposes of Section 16."293 This statement is fine as far as it goes, but it does not provide a fully articulated theory of section 16(b). It will not constitute an adequate response to the continuing concern that an exercise of an ESO, a call option, or an SAR followed within six months by a sale of the resulting shares

claimed that the acquisition of the puts should be deemed a sale under $\S 16(\mathrm{~b})$ and so the defendants should be compelled to disgorge their profits from the short-swing purchase and sale. In support of this claim, the plaintiff pointed to the new rule $16 \mathrm{~b}-6$, which deems the acquisition of a put to be a $\S 16(\mathrm{~b})$ sale, see 17 C.F.R. $\S 240.16 \mathrm{~b}-6$ (1993), and argued that "the rationale behind the new rules ... mandates the application of section $16(\mathrm{~b})$ to the transactions in this case" even though the new rules "were not effective until May 1991 and therefore not directly applicable." 984 F.2d at 1337-38. The Second Circuit rejected this argument:

"[T]he new regulatory framework not only reverses the Commission's own regulatory approach but also differs from a line of cases that, in the absence of rules to the contrary, have held that the exercise of the option (rather than its acquisition) is the section 16(b) purchase of an equity security. "... Given that the new rule is a reversal, and that the law of this circuit has been to consider only the exercise of an option a purchase or sale within section $16(\mathrm{~b})$, the district court correctly dismissed plaintiff's claim, and we affirm.

984 F.2d at 1338 (quoting Implementing Release, supra note 205, at 81,261).

292. The court obviously did not invalidate the new rule - it did not need to confront that issue - and it was careful to note that the prior precedent was " in the absence of rules to the contrary." " 984 F.2d at 1338 (quoting Implementing Release, supra note 205, at $81,261)$. On the other hand, it certainly could have taken the plaintiff's invitation to reexamine that precedent in light the new learning offered by the SEC in the process of promulgating the new rules. That it declined to do so has some significance, particularly given that it could have used Exchange Act $\S 23(\mathrm{a})$, see supra note 116, to protect the defendants from any unfairness the court felt they would suffer from having the reasoning of the new rule applied ex post facto.

293. Implementing Release, supra note 205 , at 81,263 (footnote omitted). The SEC made two other points as well, neither of which is very persuasive: (i) the old exemption was not part of a larger scheme that permitted the $\S 16(\mathrm{~b})$ matching of derivative security transactions with each other and with transactions in the underlying securities, and (ii) the old exemption did not require a six-month holding period. Id. at 81,263 \& n.126. As to the first, the SEC was leaving development of rules as to these kinds of matchings to the courts and nothing was stopping the courts from doing so. See supra sections III.C.1.b, III.C.2.b. As to the second, a six-month holding period is not in fact a necessary or appropriate part of the scheme in any case. See supra note 271 and accompanying text. Furthermore, as the discussion in the text immediately below suggests, neither of these factors is related to the central concerns expressed by the court in Greene. 
could be an occasion for the abuse of negative nonpublic information at the time of the exercise and that an exemption for such exercises prevents section 16(b) from deterring such behavior. ${ }^{294}$ In the earlier consideration of hypothetical $\mathrm{C} 2$, involving a marketpurchased call option, we suggested that a court having this concern might well find the exercise of such an option to be a transaction "within the purpose of [section 16(b)]" and the SEC's attempted exemption of the exercise to be outside the SEC's statutorily delegated powers. ${ }^{295}$ This would be all the more true with an ESO because, as we have seen, the cases dealing with ESOs have uniformly held an exercise to be a "purchase" and the earlier SEC exemption for ESO exercises was judicially invalidated. ${ }^{296}$

The only effective response to this concern is to derive a better understanding of how a statute imposing liability on the short-swing can really work to especially deter trades based on inside information, as opposed to deterring equally all trades - ones based on inside information and ones that are not. The theory in Part II provides such an understanding. The crux of this theory is that the statute can only be concerned with the possibility of abuse at the time of the first transaction; the statute deters such transactions by forcing those who would engage in them to be dediversified for at least six months; and purchase and sale should be defined in terms of when insiders assume an increase in their portfolio risk and when the increased risk ends. The class of paired transactions representing SAR exercises and ESO exercises followed by quick sales may contain some situations in which one or both of the transactions are motivated by negative inside information, but it does not fit within this scheme. The sale is the second transaction, and the first transaction - the exercise of an SAR or an ESO - should not be considered a "purchase" because it involves no change in portfolio risk. In economic terms there has not really been a short swing: there is no more reason to require the return of profits arising from these pairs of transactions than from the ordinary sales by insiders of shares they have held for a long time.

The value of this better-articulated theory for defending the SEC's 1991 reforms is well illustrated by the reasoning of the court

294. Steinberg and Landsdale, for example, have expressed this concern in commenting upon the new regime. Steinberg \& Landsdale, supra note 12 , at 65 . Their remarks are quoted earlier in this article. See supra text accompanying note 209.

295. See supra text accompanying note 209.

296. See supra text accompanying notes $248-53$. 
in Greene v. Dietz. ${ }^{297}$ The court asked rhetorically whether exemption for ESO exercises under old rule 16b-3 "was consistent with the express purpose of the statute."298 Suggesting that it was not, the court answered this question by stating: "we can still envision insider trading abuses made possible by the broad exemptions of employee stock purchase options." 299 The court gave as its single illustration a scenario involving a director who learns nonpublic negative information shortly after exercising an ESO, and then sells his shares in advance of the price decline. ${ }^{300}$ The rationale developed here shows the error in the court's reasoning. Imposing liability on ESO exercises followed by quick sales out of the fear that this scenario will arise is not consistent with the way a short-swing statute can deter insider trading because the transaction motivated by inside information - the sale - is the second transaction. Our theory illustrates that the relevant transaction for a short-swing statute is the first transaction. The court's example cannot be made more compelling by changing the facts so that the officer instead discovers the nonpublic negative information prior to first the transaction - the exercise - because that simply makes it the more general case of the concern discussed just above. As we have seen, the exercise does not involve a change in portfolio risk, and therefore the pair of the exercise and the sale does not really constitute a short-swing transaction. The exercise is simply a necessary preliminary to the sale of an interest that has been held for a longer time. ${ }^{301}$

297. 247 F.2d 689, 693 (2d Cir. 1957).

298. 247 F.2d at 693.

299. 247 F.2d at 693.

300. Specifically, the illustration involved a Director $Y$ of Company $X$ who has the right to exercise stock purchase options granted by rule $16 \mathrm{~b}-3$. The court said:

Let us assume that Company $\mathbf{X}$ announces to the public an impending merger or the negotiation of a large government contract, the news of which stimulates a significant increase in the market price of X's stock. Director Y, with no intention of defrauding the public or the corporation, immediately thereafter exercises his options and acquires a substantial amount of stock in X. Within a short time thereafter Director $Y$, through access to inside information, learns that the anticipated merger or contract has fallen through. Before this information is communicated to the public, $Y$ sells his recently acquired stock at the market peak. The public is informed and the market price of $\mathrm{X}$ stock declines accordingly. It would seem to us that such an opportunity for profittaking by insiders in a temporary and artificially stimulated market would be minimized, in accord with the purpose of section 16(b), by a requirement that insiders [who acquire stock by exercise of ESOs] . . must retain their stock for at least six months ....

247 F.2d at 693. There is in fact no artificial stimulation in this example. The higher price was not inevitably temporary. It fell because of the occurrence of a negative event subsequent to the exercise about which the insider learned before the public did. Thus the abuse is simply a sale motivated by nonpublic negative information.

301. Imposing $\$ 16(\mathrm{~b})$ in this modified situation admittedly would discourage insiders from exercising options and quickly selling upon learning of nonpublic negative information. 


\section{CONCLUSION}

Debate over section 16(b) has generated more heat than light. Critics assert that it is totally ineffective in combatting insider trading because all that an insider needs to do to avoid its bite is to wait six months before reversing the trade. Supporters of section 16(b) ignore this criticism and assert that anything but the broadest application of the statute will impede the war against insider trading. The theory developed here refines and focuses this debate. It shows that a penalty on short-swing trading, by prolonging the period of dediversification, does reduce trades based on inside information. It also shows that the penalty has costs: it reduces the attractiveness of management share ownership and share-pricebased compensation and detracts from their effectiveness as methods of reducing agency costs.

The theory does not definitely answer the question whether section 16(b) should be retained. It does, however, point to the critical factors for making that determination: one's assessments of the harm, if any, that results from insider trading and of the extent to which lower levels of share ownership and share-price-based compensation increase agency costs. ${ }^{302}$ It also identifies the minimum characteristics necessary to justify inclusion of a class of paired transactions within section 16(b)'s reach if the statute is retained: the class must contain a larger portion of potential transactions motivated by inside information than officer-and-director transactions generally.

But this is an inappropriate reason to include within $\S 16(\mathrm{~b})$ SAR exercises and ESO exercises followed by quick sales since, compared to shares acquired by ordinary purchase and held long-term, it for no good reason singles out for onerous treatment sales of shares acquired pursuant to ESOs. It will also lead to adaptive behavior - exercising early to provide flexibility - that burdens equally both guilty and innocent sales by officers and directors. The requirement advocated by the court and a requirement that insiders commit six months in advance to sell regularly purchased stock would prevent exactly the same kinds of abuses, but they are not abuses that $\S 16$ (b) was designed to remedy because they are unrelated to the short swing. For a more detailed discussion of these points, see supra section III.D.1.a.

302. There might also be differences among people as to their assessment of the amount by which the prospect of prolonged dediversification will reduce trades on inside information. A person who assesses this reduction as less, however, will also assess as less $\S 16$ (b)'s reduction in the attractiveness of managerial share ownership and share-price-based compensation. Thus an assessment that suggests reduced benefits is balanced by an assessment that suggests reduced costs. One might also argue that the beneficial effect could be easily evaded by a failure to report or by trades made in the name of someone else. This point underestimates, however, the way the whole $\S 16$ apparatus of reports and short-swing penalties will steer basically law-abiding people away from the temptation of engaging in trades based on inside information. It also ignores the fact that these methods of evasion have a significant cost that will tend to deter their use: they enhance the likelihood that the insider will be found to have violated rule $10 \mathrm{~b}-5$ because such methods of evasion make scienter easier to prove. 
This rule of statutory reach is important. Whatever one's individual assessments of the factors cited above, section $16(\mathrm{~b})$ is unlikely to be repealed in the foreseeable future. Public sentiment against insider trading is sufficiently strong that a proposal to eliminate the only provision in the Federal securities law that explicitly deals with such trading would meet overwhelming political opposition. Thus we must be sure that this rule of thumb is no cruder than it needs to be. A review of judicial and SEC decisionmaking shows there is significant room for improvement.

\section{APPENDIX}

Demonstration That an Increase in a Security's Expected Return Leads to an Increase in Its Proportion of a Portfolio of Risky Securities

Consider an officer of the issuer of security 1 . Security 2 is the other available risky security. Let $\overline{\mathbf{r}}_{1}$ and $\overline{\mathrm{r}}_{2}$ and $\sigma_{1}$ and $\sigma_{2}$ be respectively the expected rates of return and standard deviations of securities 1 and 2; let $r^{*}$ be the rate of return provided by the safe asset; let $\rho_{12}$ be the correlation coefficient of the two returns of the risky securities, and let $\overline{\mathbf{x}}_{1}=\overline{\mathbf{r}}_{1}-\mathrm{r}^{*}$ and $\overline{\mathbf{x}}_{2}=\overline{\mathbf{r}}_{2}-\mathrm{r}^{*}$. Let $\mathrm{k}^{*}$ be the optimal proportion of the dollar amount invested in security 1 to that invested in security 2 , i.e., the one that will result in the portfolio of risky securities with the highest extra return/risk ratio.

$(\mathrm{A}-1)^{303} \mathrm{k}^{*}=\frac{\overline{\mathrm{x}}_{1} \sigma_{2}{ }^{2}-\overline{\mathrm{x}}_{2} \rho_{12} \sigma_{1} \sigma_{2}}{\overline{\mathrm{x}}_{1} \sigma_{2}^{2}+\overline{\mathrm{x}}_{2} \sigma_{1}^{2}-\left(\overline{\mathrm{x}}_{1}+\overline{\mathrm{x}}_{2}\right) \rho_{12} \sigma_{1} \sigma_{2}}$

(A-2) $\frac{\mathrm{dk}^{*}}{\mathrm{~d} \overline{\mathrm{x}}_{1}}=\frac{\sigma_{2}^{2}\left(\overline{\mathrm{x}}_{1} \sigma_{2}^{2}+\overline{\mathrm{x}}_{2} \sigma_{1}^{2}-\left(\overline{\mathrm{x}}_{1}+\overline{\mathrm{x}}_{2}\right) \rho_{12} \sigma_{1} \sigma_{2}\right)-\left(\sigma_{2}^{2}-\rho_{12} \sigma_{1} \sigma_{2}\right)\left(\overline{\mathrm{x}}_{1} \sigma_{2}{ }^{2}-\overline{\mathrm{x}}_{2} \rho_{12} \sigma_{1} \sigma_{2}\right)}{\left[\overline{\mathrm{x}}_{1} \sigma_{2}{ }^{2}+\overline{\mathrm{x}}_{2} \sigma_{1}{ }^{2}-\left(\overline{\mathrm{x}}_{1}+\overline{\mathrm{x}}_{2}\right) \rho_{12} \sigma_{1} \sigma_{2}\right]^{2}}$

$$
\begin{gathered}
=\frac{\overline{\mathbf{x}}_{1}\left(\sigma_{2}{ }^{4}-\sigma_{2}{ }^{2} \rho_{12} \sigma_{1} \sigma_{2}-\sigma_{2}{ }^{4}+\sigma_{2}{ }^{2} \rho_{12} \sigma_{1} \sigma_{2}\right)}{\left[\overline{\mathbf{x}}_{1} \sigma_{2}{ }^{2}+\overline{\mathrm{x}}_{2} \sigma_{1}{ }^{2}-\left(\overline{\mathrm{x}}_{1}+\overline{\mathrm{x}}_{2}\right) \rho_{12} \sigma_{1} \sigma_{2}\right]^{2}}+ \\
\frac{\overline{\mathrm{x}}_{2}\left(\sigma_{2}{ }^{2} \sigma_{1}{ }^{2}-\sigma_{2}{ }^{2} \rho_{12} \sigma_{1} \sigma_{2}+\sigma_{2}{ }^{2} \rho_{12} \sigma_{1} \sigma_{2}-\rho_{12}{ }^{2} \sigma_{1}{ }^{2} \sigma_{2}{ }^{2}\right)}{\left[\overline{\mathrm{x}}_{1} \sigma_{2}{ }^{2}+\overline{\mathrm{x}}_{2} \sigma_{1}{ }^{2}-\left(\overline{\mathrm{x}}_{1}+\overline{\mathrm{x}}_{2}\right) \rho_{12} \sigma_{1} \sigma_{2}\right]^{2}}
\end{gathered}
$$

303. For the derivation of this expression, see Charles W. Haley \& Lawrence D. Schall, The Theory of Financial Decisions 140-42 (2d ed. 1979). 
The first expression in (A-3) equals 0 . The second expression is positive if $\bar{x}_{2}>0^{304}$ and $-1<\rho_{12}<1$ (i.e., the rather likely scenario in which returns on the two risky securities are not perfectly correlated or perfectly inverse correlated). ${ }^{305}$ Thus, under these circumstances,

$$
\frac{d k^{*}}{d \bar{x}_{1}}>0
$$

i.e., an increase in the expected rate of return of security 1 leads to an increase in the proportion of the amount invested in that security relative to the total amount invested in risky securities generally.

304. If the officer possesses no nonpublic information concerning the issuer of security 2 (which seems likely since he is not an insider of that issuer) and the securities are generally perceived to be positively correlated, $\overline{\mathbf{x}}_{2}$ should be greater than 0 in an efficient market. In other words, security 2 would be priced to provide some premium over $\mathrm{r}^{*}$, what could be earned by investors in the safe asset.

305. If $\rho_{12}=1$, the investor would invest all of his risky portfolio in the security with the higher extra return/risk ratio, i.e., the higher $\bar{x} / \sigma$. 